$$
\begin{aligned}
& \text { DOE/OR/01-1169\&D1 } \\
& \text { Y/ER-93 DI }
\end{aligned}
$$

Postconstruction Report for the Mercury Tanks Interim Action at the Oak Ridge Y-12 Plant, Oak Ridge, Tennessee

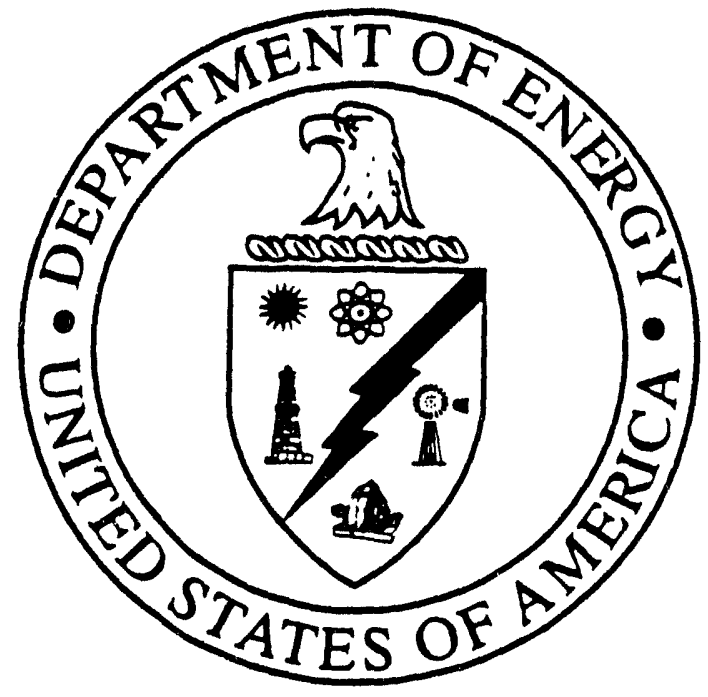


DOE/OR/01-1169\&D1

Y/ER-93\&D1

\author{
Environmental Restoration Program Division \\ Y-12 Environmental Restoration Program
}

\title{
Postconstruction Report for the Mercury Tanks Interim Action at the Oak Ridge Y-12 Plant, Oak Ridge, Tennessee
}

\author{
T. L. Voskuil
}

Date Issued-September 1993

Prepared by

Engineering Organization

Martin Marietta Energy Systems, Inc.

Oak Ridge, Tennessee

Prepared for

U.S. Department of Energy

Office of Environmental Restoration and Waste Management under budget and reporting codes CD 1072 and EW 20

\author{
OAK RIDGE Y-12 PLANT \\ Oak Ridge, Tennessee 37831-8169 \\ managed by \\ MARTIN MARIETTA ENERGY SYSTEMS, INC. \\ for the \\ U.S. DEPARTMENT OF ENERGY \\ under contract DE-AC05-84OR21400

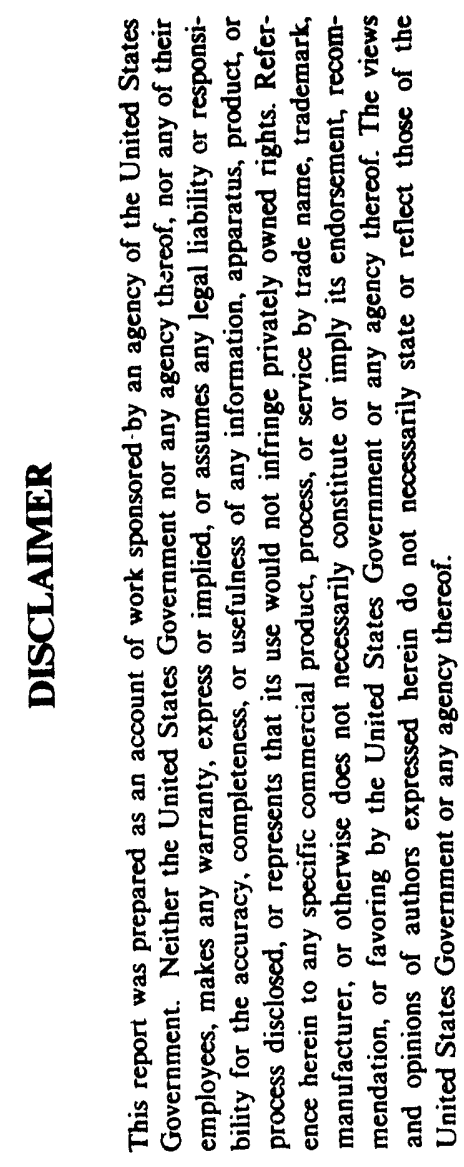




\section{CONTENTS}

ACRONYMS $\ldots \ldots \ldots \ldots \ldots \ldots \ldots \ldots \ldots \ldots \ldots \ldots \ldots \ldots \ldots$

EXECUTTVE SUMMARY $\ldots \ldots \ldots \ldots \ldots \ldots \ldots \ldots \ldots \ldots \ldots \ldots$

1. INTRODUCTION $\ldots \ldots \ldots \ldots \ldots \ldots \ldots \ldots \ldots \ldots \ldots \ldots \ldots \ldots \ldots \ldots$

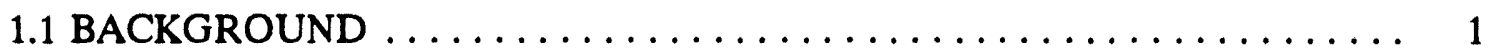

1.2 SELECTION OF REMEDIAL ALTERNATIVE $\ldots \ldots \ldots \ldots \ldots \ldots \ldots$

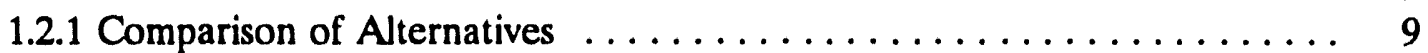

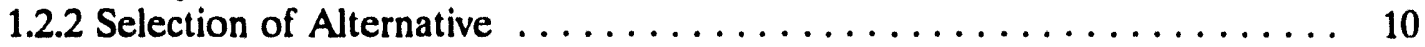

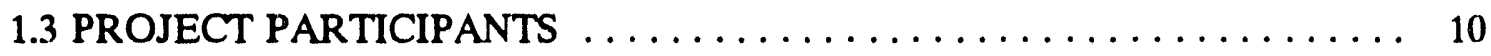

2. CHRONOLOGY OF EVENTS $\ldots \ldots \ldots \ldots \ldots \ldots \ldots \ldots \ldots \ldots \ldots \ldots$

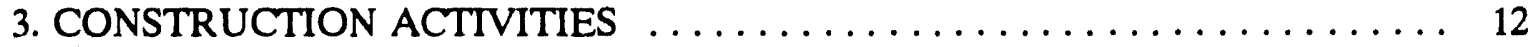

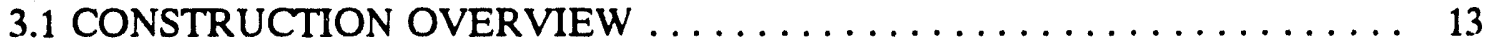

3.2 LESSONS LEARNED $\ldots \ldots \ldots \ldots \ldots \ldots \ldots \ldots \ldots \ldots \ldots \ldots \ldots \ldots \ldots$

4. PERFORMANCE STANDARDS $\ldots \ldots \ldots \ldots \ldots \ldots \ldots \ldots \ldots \ldots \ldots$

4.1 INSPECTIONS OF TANK CLEANLINESS

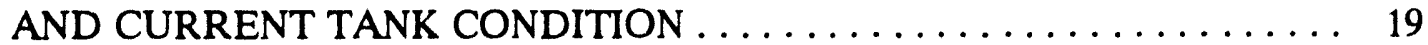

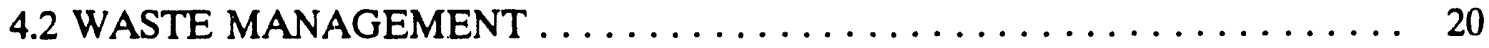

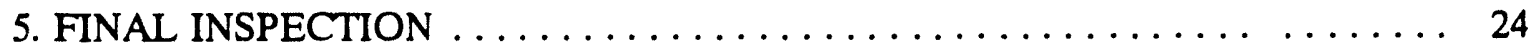

6. CERTIFICATION THAT THE REMEDY IS

OPERATIONAL AND FUNCTIONAL $\ldots \ldots \ldots \ldots \ldots \ldots \ldots \ldots \ldots \ldots$

7. OPERATION AND MAINTENANCE $\ldots \ldots \ldots \ldots \ldots \ldots \ldots \ldots \ldots \ldots$

8. SUMMARY OF PROJECT COSTS $\ldots \ldots \ldots \ldots \ldots \ldots \ldots \ldots \ldots \ldots$

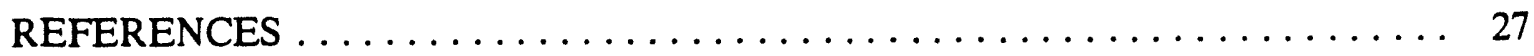

Appendix A. CERTIFIED-FOR-CONSTRUCTION PACKAGE
(TECHNICAL SPECIFICATIONS) $\ldots \ldots \ldots \ldots \ldots \ldots \ldots \ldots \ldots$ A-1

Appendix B. AS-BUILT SPECIFICATIONS . . . . . . . . . . . . B-1

Appendix C. INSPECTION PLAN $\ldots \ldots \ldots \ldots \ldots \ldots \ldots \ldots \ldots \ldots \ldots \ldots \ldots \ldots \ldots \ldots$

Appendix D. BEST MANAGEMENT PRACTICES PLAN $\ldots \ldots \ldots \ldots \ldots \ldots \ldots$ D-1

Appendix E. MODIFIED WASTE MANAGEMENT PLAN $\ldots \ldots \ldots \ldots \ldots \ldots \ldots$ E-1 


\section{ACRONYMS}

$\begin{array}{ll}\text { CERCLA } & \text { Comprehensive Environmental Response, Compensation, and Liability Act } \\ \text { CPCF } & \text { Central Pollution Control Facility } \\ \text { DOE } & \text { Department of Energy } \\ \text { EPA } & \text { Environmental Protection Agency } \\ \text { ET\&I } & \text { Equipment Testing and Inspection } \\ \text { ICP } & \text { inductively coupled plasma } \\ \text { IROD } & \text { Interim Record of Decision } \\ \text { MK-F } & \text { MK-Ferguson } \\ \text { NPDES } & \text { National Pollutant Discharge Elimination System } \\ \text { ORR } & \text { Oak Ridge Reservation } \\ \text { PCB } & \text { polychlorinated biphenyl } \\ \text { RCRA } & \text { Resource Conservation and Recovery Act } \\ \text { RMPE } & \text { Reduction of Mercury in Plant Effluent } \\ \text { TCLP } & \text { Toxicity Characteristic Leaching Procedure } \\ \text { TDEC } & \text { Tennessee Department of Environment and Conservation } \\ \text { TSCA } & \text { Toxic Substances Control Act } \\ \text { UEFPC } & \text { Upper East Fork Poplar Creek } \\ \text { WETF } & \text { West End Treatment Facility } \\ \text { WTO } & \text { Waste Treatment Organization } \\ \text { WTSD } & \text { Waste Transportation, Storage, and Disposal }\end{array}$




\section{EXECUTIVE SUMMARY}

Three underground concrete settling tanks (tanks 2101-U, 2104-U, and 2100-U) at the Y-12 Plant on the Oak Ridge Reservation in Oak Ridge, Tennessee, contained contaminated sludges contributing mercury to the Upper East Fork Poplar Creek (UEFPC). These tanks were cleaned out as an interim action under the Comprehensive Environmental Response, Compensation, and Liability Act as part of the Reduction of Mercury in Plant Effluent subproject. Cleaning out these tanks prevented the sludge that had settled in the bottom from resuspending and carrying mercury into UEFPC. Tanks $2104-U$ and $2100-U$ were returned to service and will continue to receive effluent from buildings 9201-4 and 9201-5. Tank 2101- $U$ had been abandoned and its effluent redirected to Tank $2100-U$ during previous activities. This interim action permanently sealed Tank 2101-U from the storm sewer system.

Upon removal of materials and completion of cleanup, inspections determined that the project's cleanup criteria had been met. The structural integrity of the tanks was also inspected, and minor cracks identified in tanks $2101-\mathrm{U}$ and $2104-\mathrm{U}$ were repaired.

This project is considered to have been completed successfully because it met its performance objectives as addressed in the Interim Record of Decision and the work plan: to remove the waste from the three storage tanks; to ensure that the tanks were cleaned to the levels specified; to return tanks $2100-\mathrm{U}$ and $2104-\mathrm{U}$ to service; to isolate Tank $2101-\mathrm{U}$ permanently; and to manage the wastes in an appropriate fashion. 


\section{INTRODUCTION}

\subsection{BACKGROUND}

Three underground concrete settling tanks (tanks 2101-U, 2104-U, and 2100-U) at the Y-12 Plant on the Oak Ridge Reservation (ORR) in Oak Ridge, Tennessee, contained contaminated sludges contributing mercury to the Upper East Fork Poplar Creek (UEFPC). These tanks were cleaned out as an interim action under the Comprehensive Environmental Response, Compensation, and Liability Act (CERCLA) as part of the Reduction of Mercury in Plant Effluent (RMPE) subproject. Cleaning out these tanks prevented the sludge that had settled in the bottom from resuspending and carrying mercury into UEFPC. Tanks 2104-U and $2100-U$ were returned to service and will continue to receive effluent from buildings 9201-4 and 9201-5. Tank 2101-U had been abandoned and its effluent redirected to Tank $2100-U$ during previous activities. This interim action permanently sealed Tank 2101-U from the storm sewer system.

These tanks became contaminated with mercury as a result of the operation of a columnexchange process (Colex) that separated ${ }^{6} \mathrm{Li}$ isotopes from ${ }^{7} \mathrm{Li}$ isotopes for the eventual manufacture of ${ }^{6} \mathrm{Li}$ compounds of hydrogen. Because ${ }^{6} \mathrm{Li}$ is more soluble in mercury than ${ }^{7} \mathrm{Li}$, the Colex process used large quantities of mercury as a solvent to extract the ${ }^{6} \mathrm{Li}$ isotope. The Colex process operated from 1955 to 1963 , and its machinery was located in buildings $9201-4$ and 9201-5 (Fig. 1). Mercury from Colex-related spills found its way into the sumps in the basement fan rooms of the two buildings through transport out of the building walls and foundations. The sump water, containing mercury and mercury-contaminated particles, was pumped from the basements, passed through one of the three settling tank, and entered the storm sewer system. The settling tanks captured a portion of the contaminated particles, held them as sludges, and thus prevented them from entering the storm sewer.

The three tanks are located outside of the buildings 9201-4 and 9201-5 (Fig. 2). Tanks 2101-U and 2100-U are outside of Building 9201-4, and Tank 2104-U is outside of Building 9201-5. Tanks 2101-U and 2104-U are divided into two compartments (Fig 3), and Tank 2100-U is divided into three compartments (Fig 4). Walls dividing compartments are open at the top and allow liquids to flow between compartments when the tanks are full. In addition, a small hole at the bottom of the walls permits some water to flow between compartments before they are full. The three tank sites are shown in Figs. 5-7.

In order to reduce the potential for discharges into the UEFPC, the Department of Energy (DOE) decided to remove and dispose of the contaminated materials in these tanks as an interim action. Martin Marietta Energy Systems, Inc., is under contract to DOE to manage the $\mathrm{Y}-12$ Plant and was responsible for oversight of the interim action. This action consisted of removing the contaminated sludge, oil, and water from the tanks and treating or storing these materials. MK-Ferguson (MK-F), the construction manager, removed all of the materials and managed them until they were turned over to Energy Systems. Because of differences in physical characteristics and contamination levels, the various materials were removed and treated separately. The water was pumped out and managed in several different 


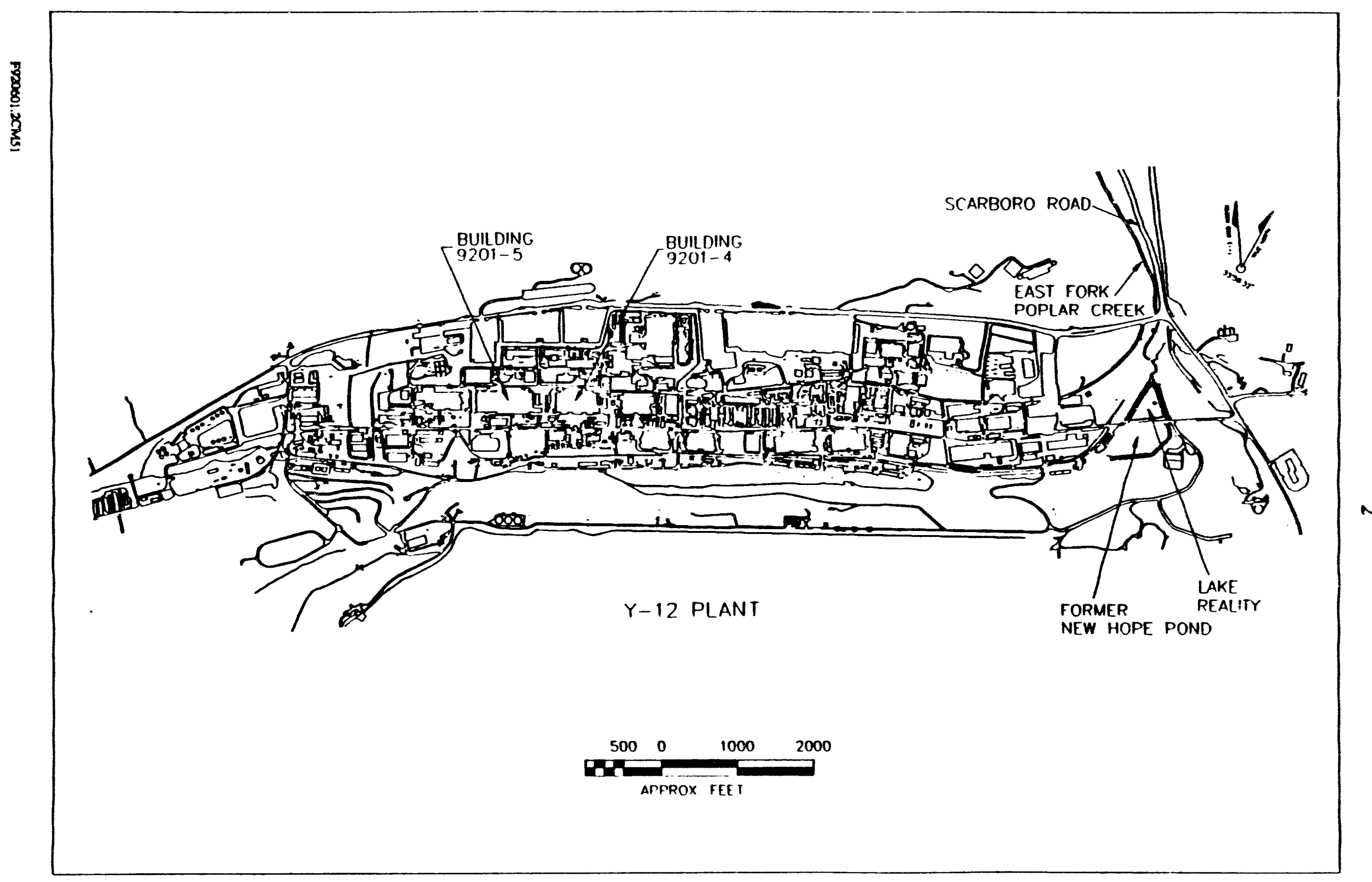

Fig. 1. Location of Buildings 9201-4 and 9201-5 at the Y-12 Plant. 


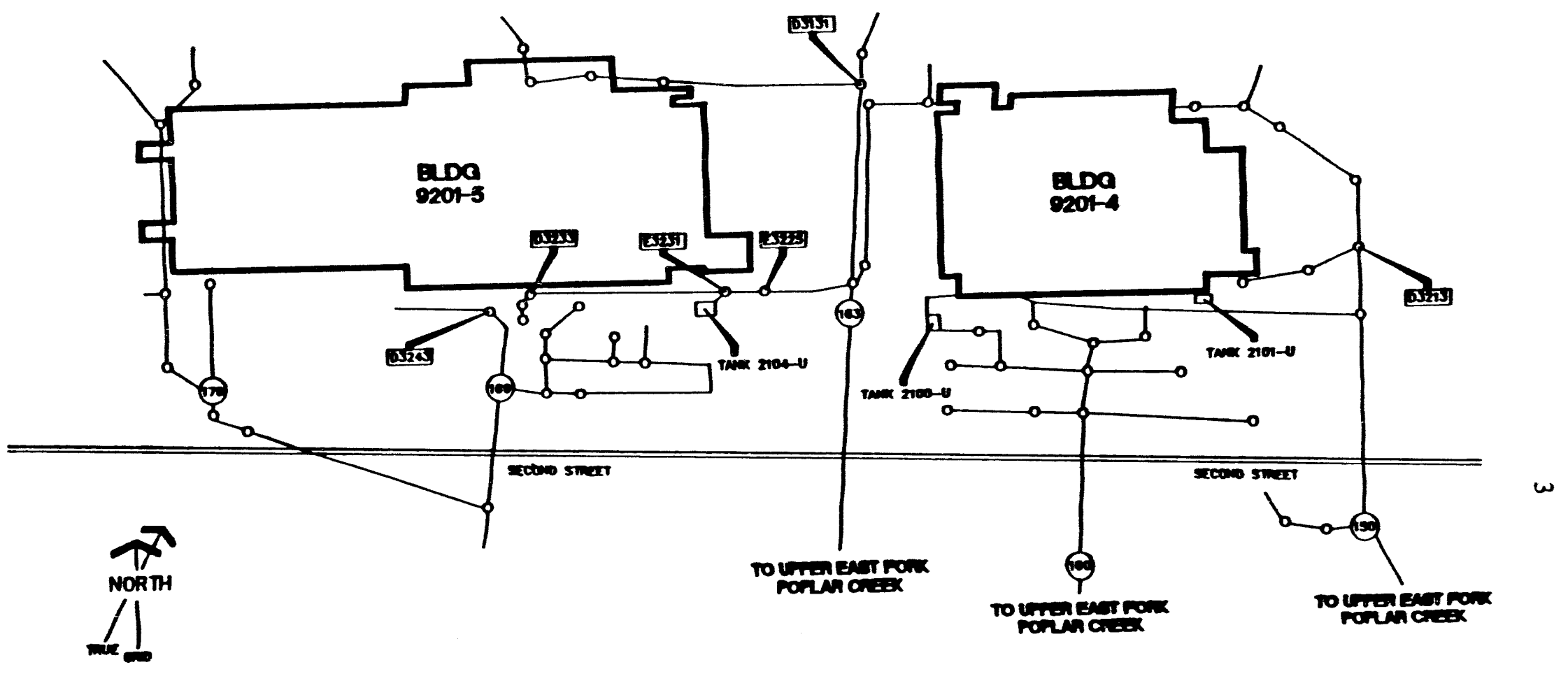

C. Ourrel Locanton

bisy-mancers 


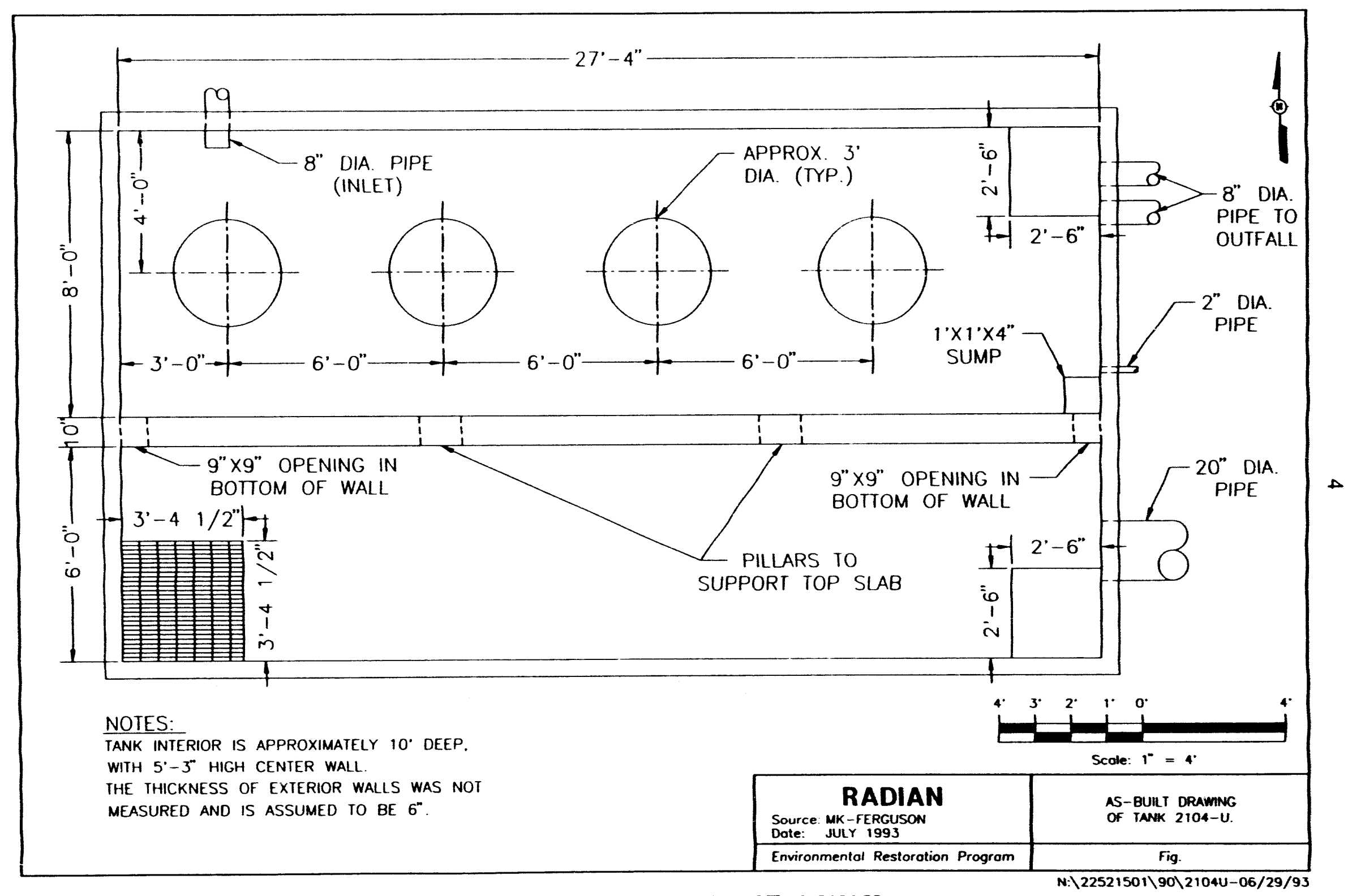

Fig. 3. As-built drawing of Tank 2104-U. 


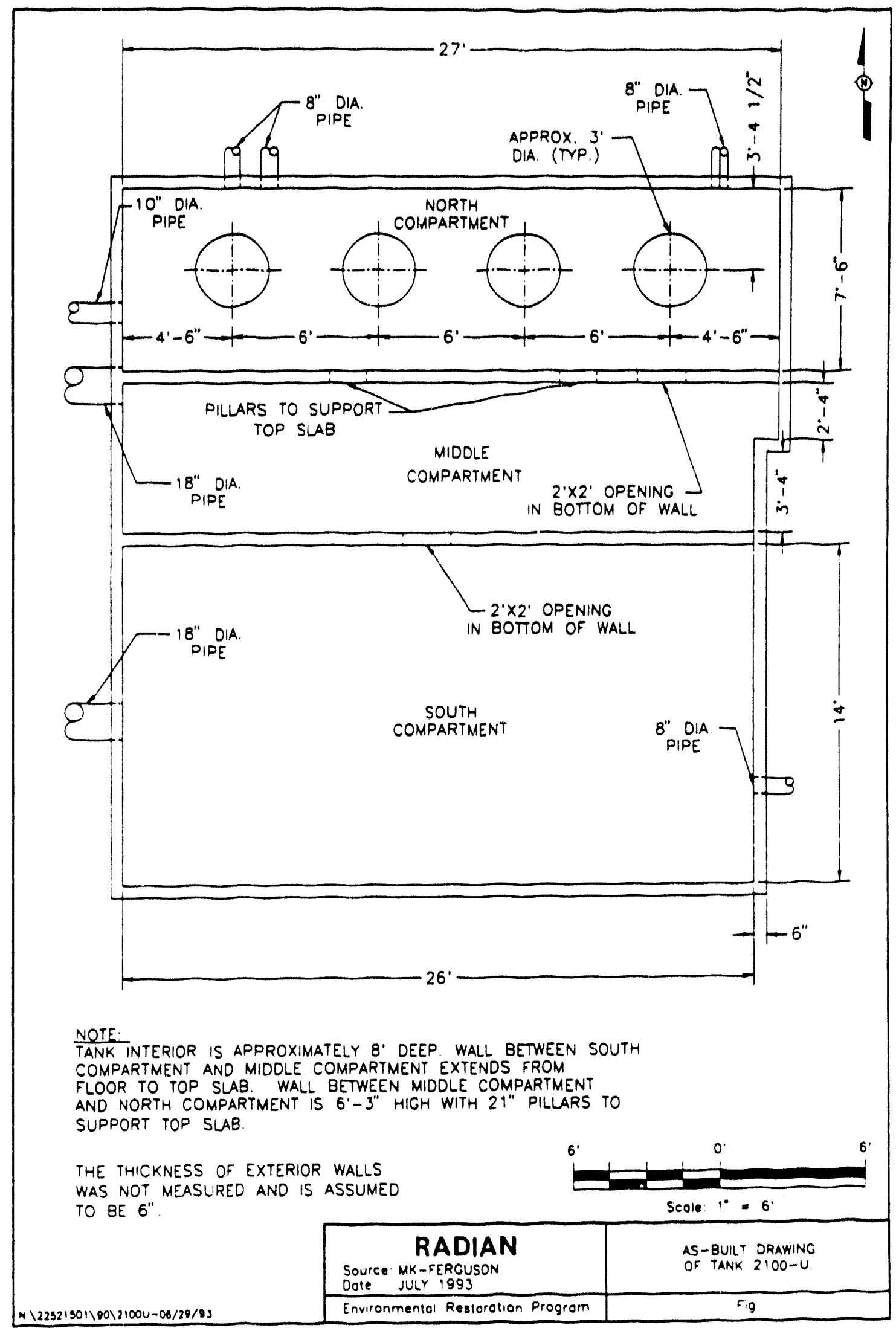

Fig. 4. As-built drawing of Tank 2100-U. 


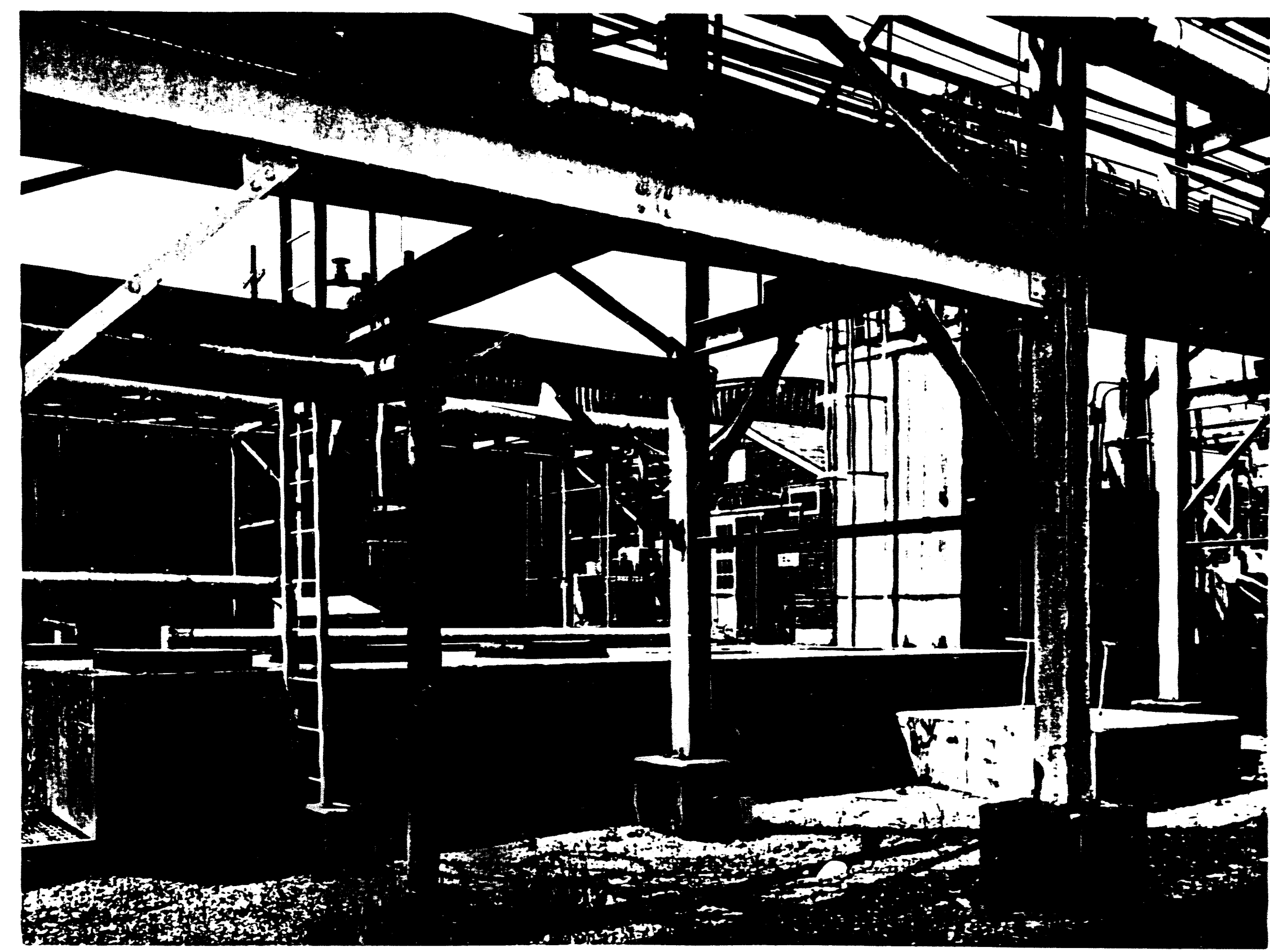

Fig. 5. Tank 2104U. 
noolz ves, 9 औt

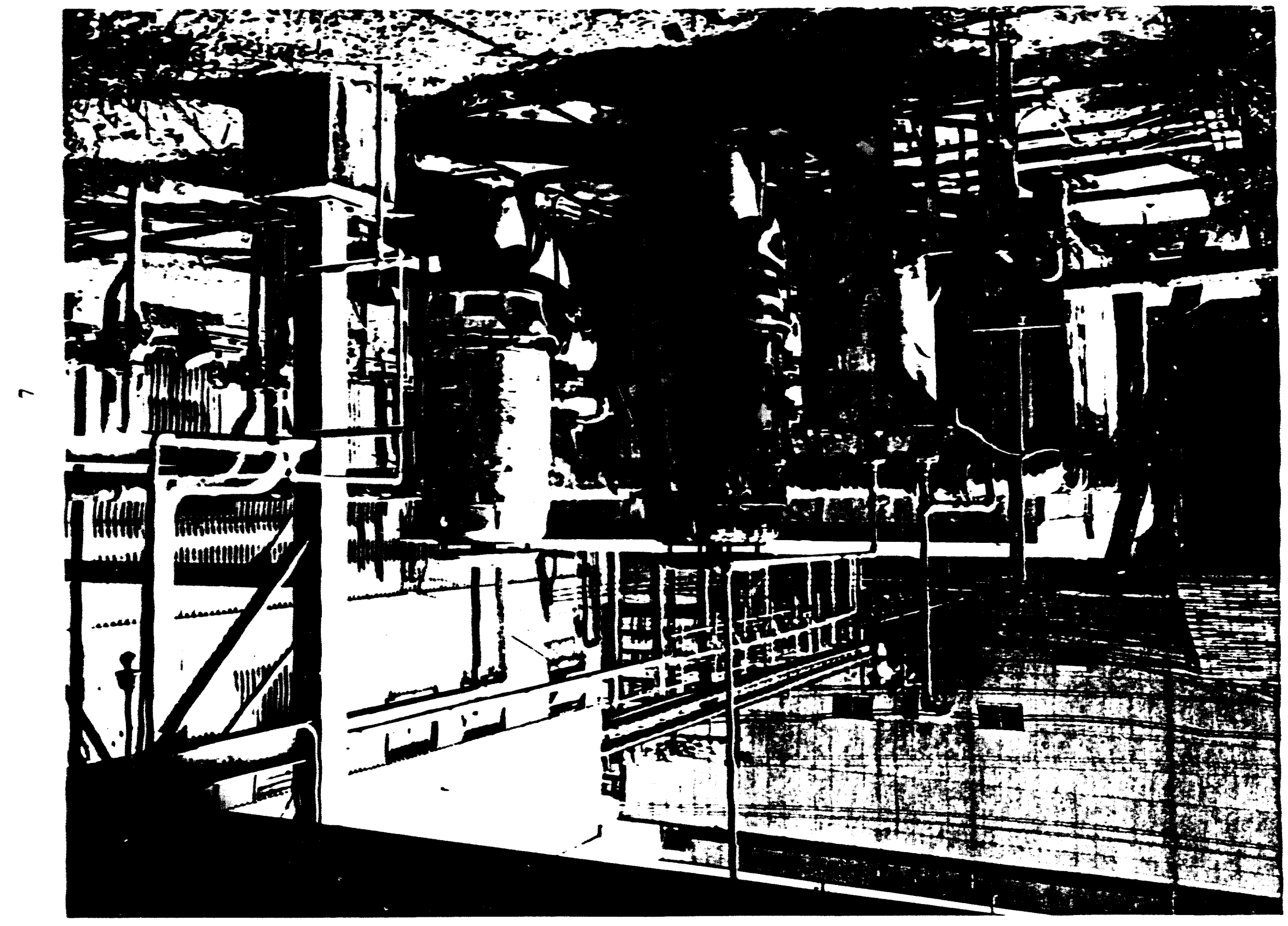


8

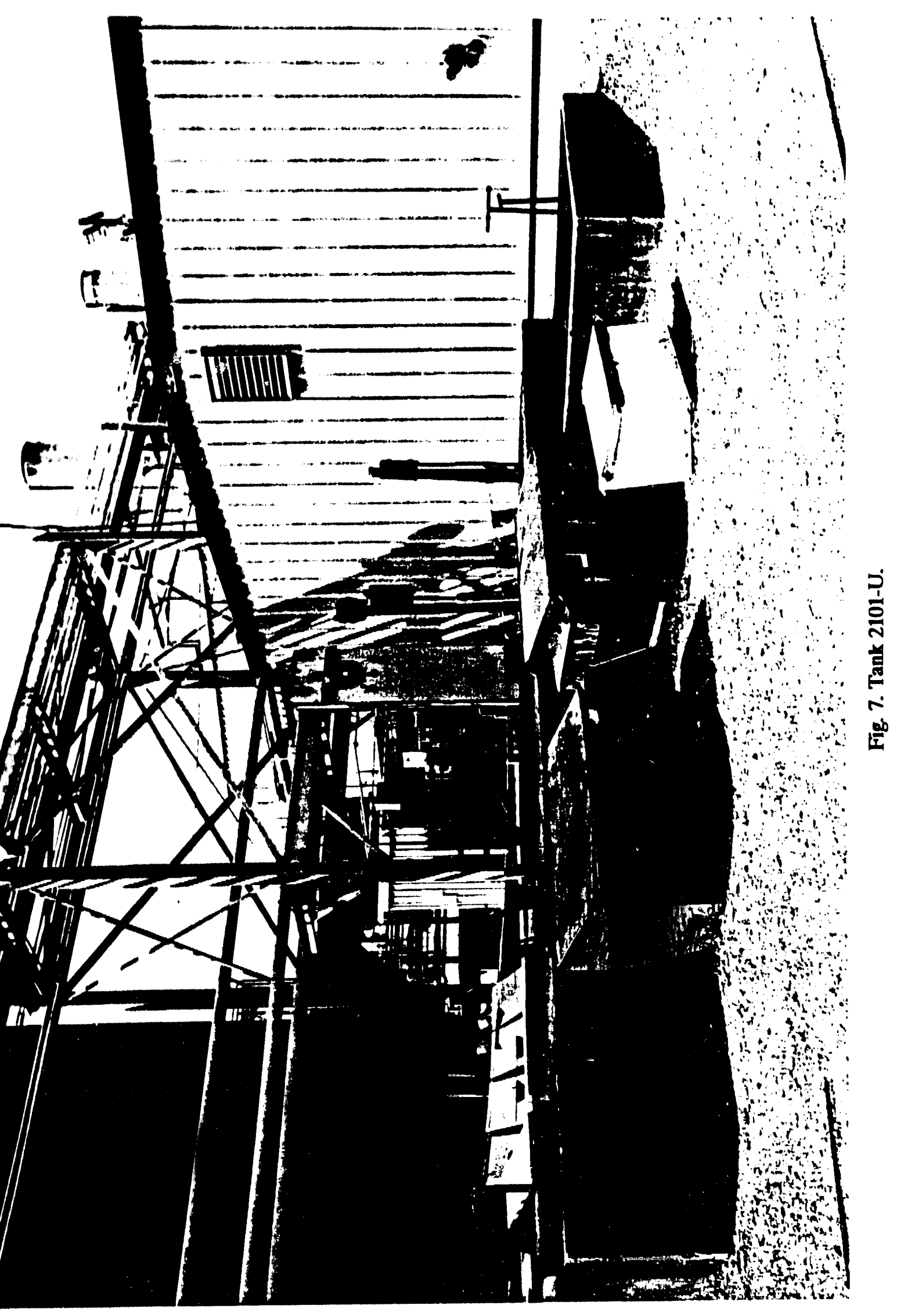


ways. The waste water was treated by the Waste Treatment Organization (WTO) within the Waste Management Division. The sludge was removed and drummed. Energy Systems' Waste Transportation, Storage, and Disposal (WTSD) Division then transported it to storage at the Oak Ridge K-25 Site. Oil and oily liquid were also removed and held in polytanks. Once in polytanks, WTSD transported these wastes to the Y-12 Plant for storage before final treatment in the K-1435 Incinerator at the K-25 Site.

\subsection{SELECTION OF REMEDIAL ALTERNATIVE}

\subsection{Comparison of Alternatives}

The alternatives evaluated for addressing mercury-contaminated sludge in the three tanks included:

Alternative 1: No Action

Alternative 2: Abandon Tanks in Place

Alternative 3: Remove and Dispose of Contaminated Sludges

These alternatives were not intended to remediate the entire mercury contamination problem in the vicinity of the tanks. This project was an interim action and was intended to reduce the amount of mercury-contaminated sludge and elemental mercury entering the storm sewer system.

Alternative 1: No Action. CERCLA requires that the no action alternative be evaluated at every site to serve as the baseline for comparison. Under this alternative, no further action would be taken to prevent mercury-contaminated sludge from entering the storm sewer system.

Alternative 2: Abandon Tanks in Place. To prevent mercury-contaminated sludges from exiting the tanks and entering the storm sewer system, the valves on the tanks would be adjusted to divert water around the tanks. This alternative was applicable only to tanks 2100-U and 2104-U; Tank 2101-U had previously been abandoned in place. Existing valves on tanks $2100-U$ and $21(14-U$ would be opened to allow water pumped from the fan room sumps to be discharged directly to the storm sewer. The tanks would be cleaned and removed at a later date when buildings $9201-4$ and 9201-5 were decontaminated and decommissioned.

While this alternative reduced the possibility of mercury-contaminated sludge in the tanks from entering the storm sewer, it did not provide the opportunity for sludge and mercury pumped into the tanks to settle before being discharged to the storm sewer.

Alternative 3: Remove and Dispose of Contaminated Sludges. This alternative removed mercury-contaminated sludge, liquids, and solids from the tanks. Oil and oily water in Tank 2101-U would be removed and sent to an ofl-site permitted hazardous waste facility for treatment and disposal. Mercury-contaminated sludge would be removed from tanks $2100-\mathrm{U}$ and $2101-U$ and sent to an off-site permitted hazardous waste management facility. Mixed wastes in Tank 2104-U would be dewatered and sent to a permitted hazardous waste storage facility within ORR. Water removed from all three tanks before sludge removal would be 
filtered and sampled for hazardous and radiological contamination and sent to an on-site facility for treatment.

This alternative removed a known source of mercury-contaminated sludge from contact with water in the storm sewer system. It also allowed for the continued use of tanks 2100-U and 2104-U to trap sludge and suspended particles of mercury pumped from the fan room sumps.

\subsubsection{Selection of Alternative}

Alternative 3, removal and disposal of contaminated sludge, was the preferred alternative for the tanks. This alternative provided the best balance with respect to U.S. Environmental Protection Agency (EPA) criteria used to evaluate alternatives. Although this interim action does not completely prevent mercury from entering the storm sewers, it does remove known sources of contamination currently in direct contact with water entering the storm sewers. Alternative 3 also achieved a risk reduction through the removal of the contaminated material contained in the tanks. This remedy, however, is not the final solution for eliminating mercury from the storm sewer system; it is an interim action and only one action performed by the RMPE subproject.

\subsection{PROJECT PARTICIPANTS}

MK-Ferguson provided construction management and direct-hire construction.

Analysas Corporation provided the site safety and health officer.

Radian Corporation produced the work plan (Radian 1992).

Energy Systems was the integrating contracting and provided project management and Title III and construction support.

DOE was the only federal agency involved in the planning and oversight of the interim action at the Y-12 Plant Mercury Tanks.

The Tennessee Department of Environment and Conservation (TDEC) and U.S. EPA supplied CERCLA regulatory authority under the Federal Facility Agreement.

\section{CHRONOLOGY OF EVENTS}

December 21, 1989

June 28, 1991

June 30-July 31,1991
The ORR was placed on the National Priorities List.

The interim action proposed plan (Van Ryn 1991) was released to the public.

Public comment period was held. 
July 22,1991

September 1991

November 17, 1992

November 19, 1992

November 25, 1992

December 11, 1992

Tank 2104-U

December 14, 1992

January 4, 1993

January 4-13, 1993

January 7, 1993

January 9, 1993

January 11, 1993

January 15, 1993

January 15, 1993

January 15, 1993
Public comment meeting on the interim action proposed plan was held.

The interim action record of decision (Radian 1991) was approved by EPA and TDEC.

The certified-for-construction package was issued, pending work plan approval. (The certified-forconstruction package is included in this postconstruction report as Appendix A.)

The remedial action work plan (Radian 1992) was appróved by TDEC.

The remedial action work plan was approved by EPA.

The construction kickoff meeting was held.

Site preparation began.

Building 9201-5 outage began. This outage stopped all flow of water to the tank for the duration of the remedial action and prevented potentially contaminated material from entering the storm sewer system.

The inlet valve to the tank was replaced and the bypass line was blocked.

Removal of sludge from the tank began.

The tank was inspected for cleanliness to determine if cleanup goals had been met. The tank met cleanup goals.

The tank was inspected by Equipment Testing and Inspection (ET\&I), which recommended that several minor cracks be repaired.

Building 9201-5 outage released.

Building 9201-5 outage ended.

Remediation activities were completed, and the tank was returned to service. 
Tank 2100-U

January 11, 1993

Site preparation began.

January 20, 1993

Removal of water and sludge from the tank began.

February 17, 1993

A small hole in the tank was patched.

February 23, 1993

The lank was inspected for cleanliness to determine if cleanup goals had been met. The tank met cleanup goals.

February 23, 1993

The tank was inspected by ET\&I, which reported the tank to be in acceptable condition.

February 25, 1993

Remediation activities were completed, and the tank was returned to service.

Tank 2101-U

January 25, 1993

Site preparation began.

March 5, 1993

Removal of water and sludge from the tank began.

March 17, 1993

The tank was inspected for cleanliness to determine if cleanup goals had been met. The tank met cleanup grals.

March 18, 1993

The lank was inspected by ET\&I, which recommended that several minor cracks be repaired.

March 30, 1993

Cracks identified in the ET\&I inspection were sealed.

March 31, 1993

Remediation activities were completed, the tank was isolated, and demobilization of MK-F completed.

April 5, 1993

DOE signed the final inspection and acceptance report for the entire project.

\section{CONSTRUCTION ACTIVITIES}

This section describes the construction activities that occurred at each site and the lessons learned during project activitics. 


\subsection{CONSTRUCTION OVERVIEW}

Construction activities were completed sequentially at each of the three tanks that were remediated in this interim action. These activities included the following:

- site preparation activities,

- removal of water and sludge from the tanks,

- site demobilization activities, and

- waste management activities.

Because there were many similarities among site preparation activities at each of the sites, these activities will be described in general terms below. Following the general discussion, activities unique to the each tank will be described. Project requirements are described in greater detail in the certified-for-construction package (Appendix A). Physical modifications made to the tanks are documented in the as-built drawings (Appendix $B$ ).

Site Preparation Activities. Site preparation activities included activities that prepared each tank site for removal of water and sludge from the tank. With the exception of the first site, these activities were begun at a new site prior to completion of the work at the previous site. Site preparation activities included:

- installation and preparation of shower and office trailers,

- installation of temporary utilities (electricity and plumbing),

- completion of a radiation survey by site safety officers,

- installation of potable water,

- preparation of a drum staging area,

- placement of two layers of plastic on top of the tank for spill control,

- construction of a temporary facility over the tank,

- construction of a confined space entrance area,

- preparation of a decontamination area on top of the tank,

- placement of temporary cords and lights, and

- construction of stands for instruments and flagging.

Figure 8 shows an active site with the support structures that were constructed during site preparation activities in place.

Tank 2104-U. Site preparation activities, or mobilization, at Tank $2104-U$ began on December 14, 1992 and continued until January 7, 1993, when waste material began to be removed from the tank.

The primary problem encountered during mobilization was difficulty in operating the two valves controlling the flow of water to the tank. An inlet valve controlled the flow of water into the tank and a bypass valve controlied the flow of water to a bypass line that carried water into the storm sewer system (Fig. 9). Closing the inlet valve was a high priority because its closure would prevent water from flowing into the tank while it was being cleaned out. Because the inlet valve was inoperable, it became necessary to replace it. The valves were located in a valve pit, and the first step in replacing them was removal of the water and 


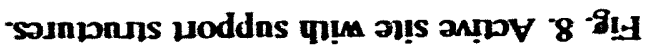

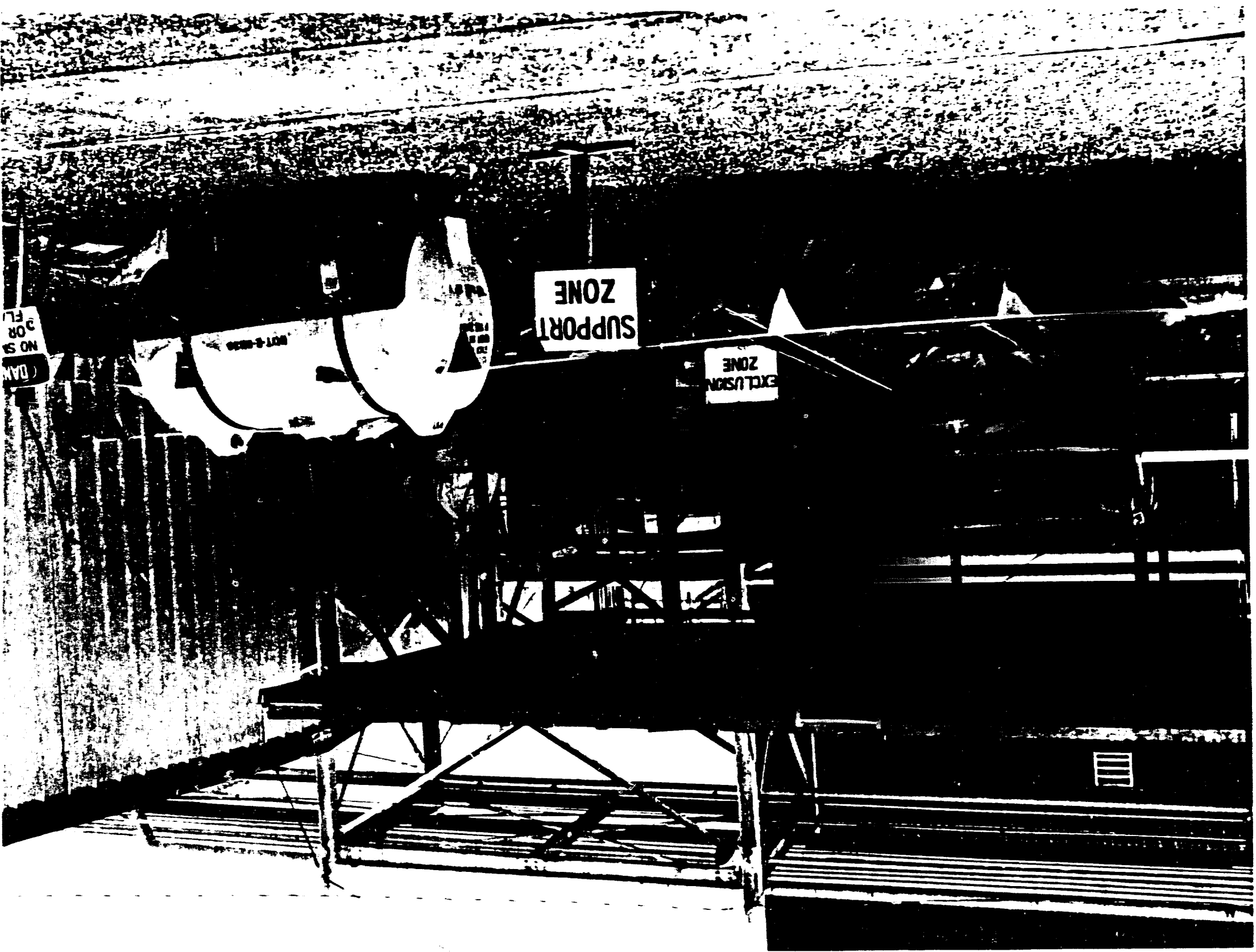




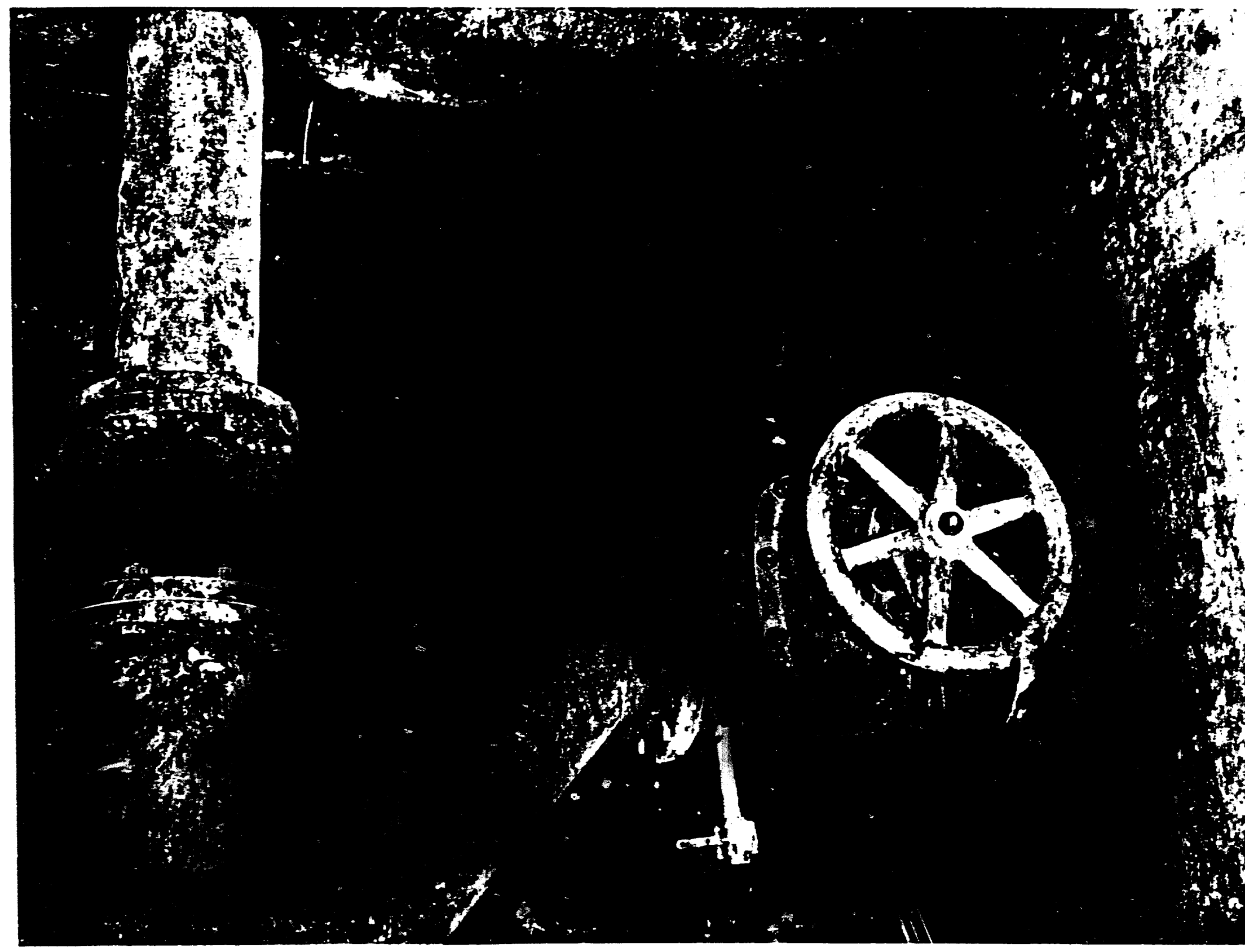

Fig. 9. Tank 2104-U inlet valve and bypass valve. 
sludge that had accumulated in the pit. Once the pit water was sampled and found to be clean, it was pumped through a 50-micron filter and a 5-micron filter and then into the storm drain. The sludge in the valve pit was removed and stored in 55-gal drums. The sludge in these drums was later dewatered, and the drums moved to the drum staging area. Work replacing the valves began on January 4,1993 . When the old valves were removed, they were found to be contaminated with mercury and radioactive constituents and thus required handling as hazardous waste. The old valves were transported to the radioactive metal salvage yard. The bypass line was also discovered to be contaminated. Thus, in order to avoid releasing potentially contaminated material into UEFPC by using the contaminated bypass line, an extended building outage was obtained from January 6 to January 15, 1993 for several machines in Building 9201-5. These machines included two process water pumps with wet seals and three chuck vacuum pumps. This outage was necessary because the source of water to Tank 2104-U originated as cooling water from these machines and not from the basement sumps as had been assumed when work started. Because the bypass line was half full of sludge and radioactively contaminated, the bypass line was permanently blocked off by installation of blind flanges. Work on the valves and bypass 'lines was completed on January 13, 1993.

The tank itself was cleaned out while the building outage was in effect. On January 6, 1993, the lids to the tank openings were removed, and the tank was found to contain only minimal sludge and no water. By January 9 , the tanks had been cleaned of the sludge. The sludge removed from Tank $2104-U$ weighed $2480 \mathrm{~kg}$ and filled 14 drums. The Energy Systems construction engineer also inspected the tank for cleanliness on this day and found it to be clean. All loose material had been removed, and there were no signs of mercury and no mercury vapors. Pipe inlet and outlets had been cleaned of loose material as far as could be reached.

On January 11, ET\&I inspected the inside of the tank and found the following:

- The north wall had three cracks: one from the top of the wall to the bottom, and two

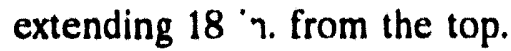

- The west wall had one crack extending $18 \mathrm{in.}$ from the top of the wall.

- The baffle wall had four cracks, three of which ran all the way through the wall.

ET\&I recommended that all the cracks be patched, and the cracks were sealed with an epoxytype paint on January 14 . The Building 9201-5 outage was released at 3 p.m. on January 14 , and Tank 2104-U was placed back in service on the morning of January 15.

Tank 2100-U. Mobilization at Tank 2100-U begar on January 11, 1993. Mobilization activities required removal of several items, such as a small shack, pipes, conduits, and pumps, from the top of the tank in order to gain access to the tank itself. By January 20, mobilization activities were complete and the cleanup crew began pumping water from the tank into waste water tankers. Removal of material from Tank 2100-U was complicated by two factors: the tank held more water and sludge than was expected, and sources of water to the tank had never been precisely identified. Pumping continued until two tankers had been filled on January 22. At this point, pumping stopped because of a lack of available tankers. On January 26, a meeting of key project management personnel was called, and the team decided to begin pumping water from the tank into the storm sewer because of the lack of available tankers. WTO had completed treatability analyses of the waste water that had been pumped into the first two tankers, and the results indicated that the waste water could be released into 
the storm sewer system with no adverse effects to UEFPC water quality. To ensure that contamination was not pumped into the storm sewer, pumping was stopped when the water level approached the sludge layer. The water was also passed through a 50-micron filter and a 5-micron filter prior to release into the storm sewer. The cleanup crew began pumping the water from Tank $2100-U$ into the storm sewer later that afternoon. UEFPC was visually checked periodically while the water was being pumped to the storm sewer, and no noticeable change was seen. In addition, routine Y-12 Plant monitoring of UEFPC did not identify any increased levels of contaminants while the water from the tank was being pumped into the storm sewer system. Pumping water into the storm sewer continued until January 28 , when the water level neared the sludge layer. The same day a new tanker was delivered to the site, and water was pumped into it. At this time, the tank was entered to determine the source of the continuing flow of water. The water source was an 8-in. line from Building 9201-4 fan room sumps. This line was rerouted with a plug and hose to the tank's outfall. Pumping water from 2100-U into the tanker continued. Pumping was slow because the filters frequently needed to be replaced as they became clogged with sludge because of the low water level. Once the water was removed, the sludge on the bottom of the tank was removed. Radsorb (see Sect. 3.2) was mixed with the sludge prior to removal to facilitate handling of the very watery sludge. Sludge removal continued for 2 weeks, until February 12. Final cleanup of the tank began on February 15 and involved several tasks, including removal of a piece of steel pipe from the south chamber (the pipe was transported to the radioactive metal salvage yard); cleaning out the 18-in. concrete pipe connecting the middle and south chambers; and cleaning the chambers with a high-pressure hose. The sludge removed from Tank $2100-U$ weighed $18,716 \mathrm{~kg}$ and filled 107 drums.

The tank was inspected on February 23, 1993, upon completion of the cleaning activities. The cleanliness inspection found the tank to have been cleaned satisfactorily. ET\&I inspected the three compartments of Tank 2100-U and reported that the tank appeared to be in satisfactory condition. They did not recommend any additional work. Tank 2100-U was returned to service on February 25.

Tank 2101-U. Site preparation work at Tank 2101-U began on January 25 and was completed on March 4.

Pumping of the oil and oily water from this tank began March 4 and was completed March 8 (the next work day). Removal of tank sludges began on March 9 and continued until March 16. Inspections were completed on March 17. The tank was found to be cleaned satisfactorily. However, ET\&I found a small crack midway on the south wall, $\sim 6 \mathrm{ft}$ from the floor; a crack on the west wall of the baffle wall; and several cracks on the north wall. ET\&I recommended that all cracks be patched as was done in Tank 2104-U. These cracks were patched on March 30. The sludge removed from Tank $2101-\mathrm{U}$ weighed $10,681 \mathrm{~kg}$ and filled 42 drums.

Demobilization began on March 18. Whereas Tank 2101-U had been abandoned and its effluent redirected to Tank 2100 -U during previous projects, this project permanently isolated it during demobilization activities by blocking the inlet and outlet pipes with steel plates inside the tank. Demobilization and isolation of Tank 2101-U were completed on March 31.

Personnel safety. The safety of site personnel was a primary concern throughout project activities. Health and safety requirements are documented in Appendix A. Once site work 
began, but before personnel entered the site, the site was characterized for potential personnel hazards. This characterization determined the levels of personnel protection equipment that personnel were required to wear on site.

\subsection{LESSONS LEARNED}

Positive lessons learned included one project management lesson, concerning eariy project involvement with the subcontractor, and two product use lessons, one concerning Radsorb and one concerning PremAire. One negative lesson learned involved the time of year the work was done.

Early project involvement with the subcontractor. The construction subcontractor on this project was MK-F. The Energy Systerns project team involved MK-F early in the project planning phase. This involvement helped the project team avoid planning designs that would prove impossible for MK-F to complete. Thus negotiations over what MK-F could and would do after the project was planned were avoided, and time was saved. The project management team felt that this early involvement of MK-F was a key in the successful and early completion of this project.

Radsorb. Radsorb, a proprietary product produced by Environmental Scientific, Inc., of Raleigh, North Carolina, was used to absorb excess water in the drums containing removed sludges and to facilitate removal of sludges from Tank $2100-U$. This product was very useful because it can absorb excess water without increasing much in volume. Physically, Radsorb is like a fine sand, but when it absorbs water, it produces a gel. Radsorb also comes in Radpads that fit a 55-gal drum. These pads can be placed in a drum and will absorb standing water. During the mercury tank cleanout, drums were allowed to settle for a few days, and then a Radpad was placed in them to absorb the water that was left on top of the drummed material. The Radpads increased in height from $1 / 16$ in. to 2 in. during this process. The use of these products is limited to water absorption, however. They do not absorb oils, and their efficiency is decreased when used with oil-water mixtures. Radpads were left in the drums when they were sealed, and thus the Radpads were managed with the waste they absorbed.

Radsorb saved time and reduced waste volumes on the mercury tanks cleanout. Radsorb was used primarily with tanks $2100-U$ and $2104-U$ to reduce drummed waste volumes. It was also used at Tank $2100-U$ to "solidify" the watery sludges prior to removal. In the gel form, these wastes proved easier to handle and thereby speeded handling time. Removal of the sludges was reduced from an estimated 4 days to 1 day. Because of Radsorb's limitations in dealing with oils and oil-water mixtures, it was not used with Tank 2101-U, the tank containing oil and oily liquid.

PremAire. The PremAire supplied-air respirator, manufactured by Mine Safety Appliances Company of Decatur, Georgia, was used to supply air to workers while working in the tanks. PremAire is a full-face, pressure-demand, Type C supplied-air device. The base unit features a waist-mounted manifold that permits modification for site conditions in a number of ways, including: (1) a supplied-air respirator with an emergency-escape air cylinder; (2) a combination supplied-air/air-purifying device; (3) a supplied-air respirator with a vortex tube that can cool or warm the person wearing the protective clothing; and (4) a supplied-air 
respirator with dual-air-supply capability. Each option can be combined or used individually. On-site workers were pleased with the flexibility and ease of use of the PremAire system.

Time of year. The work on these tanks was done during the winter of 1992-1993 and the spring of 1993. The project team recommends that work of this nature be done during the spring or fall. If the work is done at these times of the year, it avoids the heat of the summer, which can be health-threatening when working in tanks in full protective suits, and the cold of winter, which may freeze air lines and other equipment.

\section{PERFORMANCE STANDARDS}

Performance standards for this interim action addressed two areas: (1) cleanliness of the tanks once the contaminated material had been removed and (2) waste management of material removed from the tanks. Cleanup standards for the removed material were not addressed by this project because it removed waste, but the interim record of decision (IROD) did not require the waste to be cleaned. Quality assurance requirements were defined in Appendix B of the remedial action work plan (Radian 1992).

\subsection{INSPECTIONS OF TANK CLEANLINESS AND CURRENT TANK CONDITION}

Once the waste material had been removed from the tanks, each tank underwent two inspections-one for cleanliness and one for structural integrity.

Cleanliness inspections were conducted by the Energy Systems construction engineer to ensure that the guidelines described in project inspection plan (Appendix C) were met. These inspections occurred while MK-F actively controlled the sites according to Hazardous Waste Operations and Emergency Response site access rules. Cleanliness standards included:

- absence of any standing liquid (water) in the tank,

- cleanliness of tank floors and walls to broom clean,

- absence of any visible standing mercury in the tank, and

- absence of sludge in piping inlets and outlets as far as could be reached.

A tank inspection checklist was used to document these inspections.

The project inspection plan also required ET\&I to evaluate the current condition of the tanks by giving each tank a complete internal visual inspection as described in ET\&I Procedure Y50-65-EI-012, a standard departmental guideline. Within 5 days of inspection, ET\&I supplied written documentation of the conditions noted during inspection and made recommendations to correct the deficiencies. These inspections were performed as a best management practice and were not a regulatory requirement.

The tanks were each inspected as planned, and all passed their cleanliness inspection. However, ET\&I noted minor cracks in tanks $2101-U$ and $2104-U$. These were easily fixed by 
sealing with an epoxy-type paint. The results of these inspections are described in greater detail in Sect. 3.1.

\section{WASTE MANAGEMENT}

Waste management varied with the wastes that were removed from the tanks: water from tanks 2100-U and 2104-U, sludge from all three tanks, and oil and oily water from Tank 2101-U. In addition, personal protective equipment (PPE) waste was managed separately from the wastes removed from the tanks.

While waste management varied with the type of waste and the type of contamination, several elements were common to the management of all wastes. First, UCN-2109 forms (Request for Transfer, Storage, or Disposal of Wastes forms) were required for each type of waste from each of the three tanks. AlI UCN-2109 forms were completed by Energy Systems personnel. Secondly, a staging area (Fig. 10) for filled polytanks, drums, or tankers was set up within each work zone. These staging areas provided adequate secondary containment for containers holding liquids. Drums holding wastes were placed on pallets with adequate aisle space to allow inspections. Containerized waste was stored at the site until it was transported to a treatment facility or suitable long-term storage location.

Waste characterization data were generated by Waste Management to determine how ta manage the waste. Sampling was completed by taking multiple grab samples of the sludge and water. Sludge samples were analyzed for Toxicity Characteristic Leaching Procedure (TCLP) metals, TCLP volatiles semivolatiles, total mercury, polychlorinated biphenyls (PCBs), total $U$, and $\%{ }^{235} \mathrm{U}$. Water samples were analyzed for inductively-coupled plasma analysis metals, volatiles, semivolatiles, total mercury, PCBs, cyanide, acidity, pH, anions, phenols, oil and grease, total organic carbon, and total $U$. The results (Tables 1 and 2 ) showed that the primary contaminant in the tanks was mercury, but radioactive uranium was also found in all of the tunks, and PCBs were found in two of the tanks (Tanks 2101-U and 2104-U). This contaminated material was composed of water and sludge (and oil and oily liquid in Tank 2101-U). The sludge was more highly contaminated than the water or oil. However, the sludge samples did not fail the TCLP for mercury, even though there were high levels of total mercury.

Waste management requirements for this project were defined in the certified-forconstruction package (Appendix $A$ ). This package contained the best management practices plan (Appendix D), which describes how to manage waste water and drummed waste, and the original waste management plan. The waste management plan presented in the certified-forconstruction package was later modified (Appendix E).

Waste water. Prior to acceptance of the waste water, Waste Management collected multiple samples directly from the three tanks. A portion of the samples were sent to the Y.12 laboratory for analysis, and the remainder was sent to WTO for testing to determine treatability within the WTO treatment facilities. The results were compared to the waste acceptance guidelines for these facilities. These serve only as guidelines for treatment of waste waters and are used to identify waste waters with constituents of high concentrations that may prove difficult to treat. To confirm its treatability, WTO performed jar tests prior to acceptance of the mercury tank waste. 


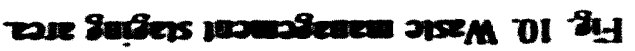

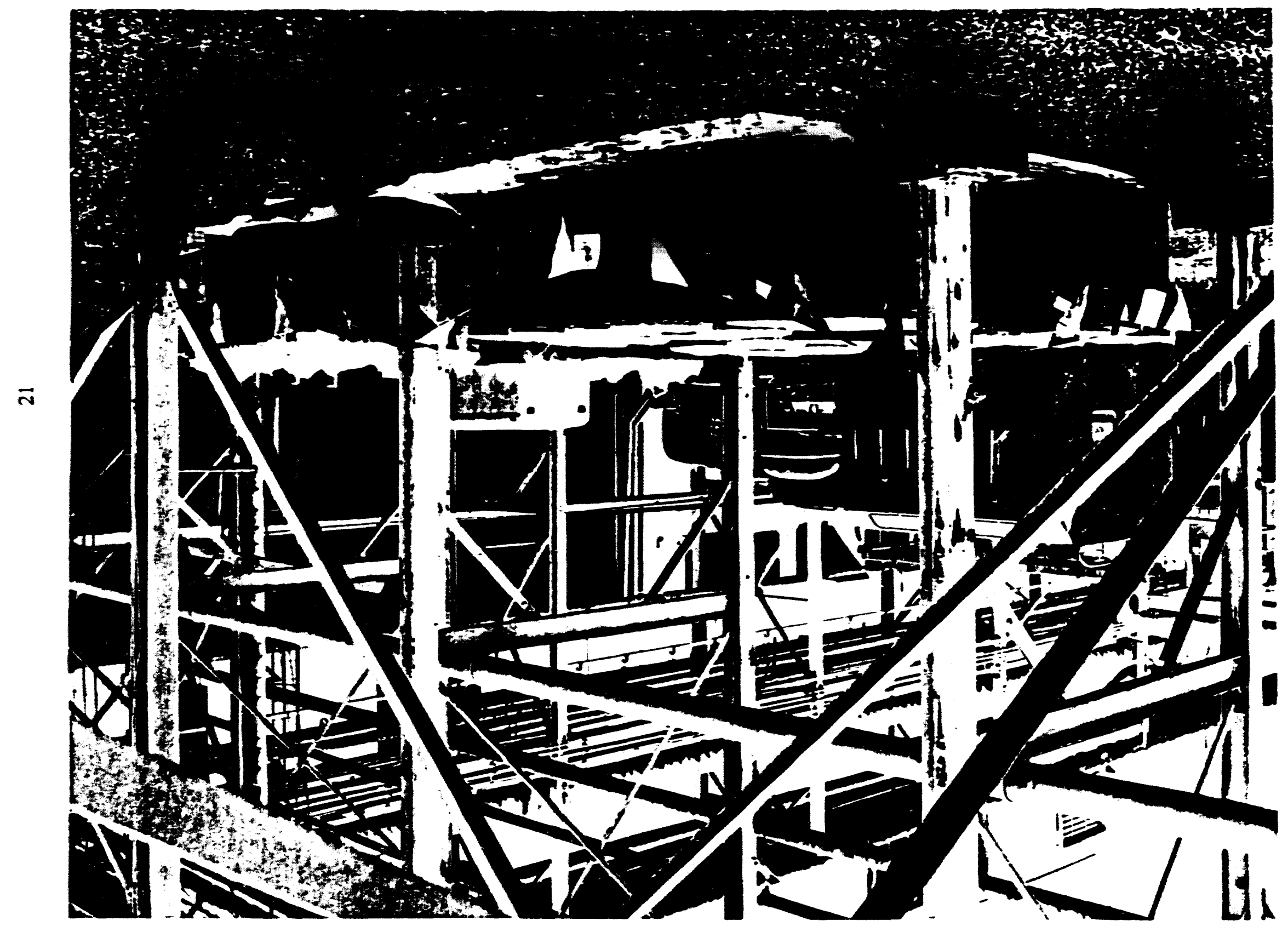


Table 1. Ranges of parameters of concern for Waste Mancgement's waste water characterization data

\begin{tabular}{|c|c|c|c|c|c|c|}
\hline Tank & $\begin{array}{l}\text { Total U } \\
(\mathrm{mg} / \mathrm{L})\end{array}$ & $\%{ }^{2 \times 5} \mathrm{U}$ & $\begin{array}{c}\text { PCBs } \\
(\mathrm{mg} / \mathrm{L})\end{array}$ & $\begin{array}{c}\text { Oil and grease } \\
(\mathrm{m} g / \mathrm{L})\end{array}$ & $\begin{array}{c}\text { Total } \mathrm{Hg} \\
(\mathrm{mg} / \mathrm{L})\end{array}$ & $\begin{array}{l}\text { Other } \\
\text { (mg/L) }\end{array}$ \\
\hline \multicolumn{7}{|c|}{ Wastc watcr } \\
\hline $2100-U$ & $<0.14-0.175$ & NA & udl & udl-140 & $24-150$ & $\begin{array}{c}\mathrm{Pb}(\text { udl-22) } \\
\mathrm{Cr}(0.2-6)\end{array}$ \\
\hline $2104-U$ & $<0.15$ & 0.21 & adl & udl & udl & $\mathrm{Pb}(6.8 \mathrm{ppm})$ \\
\hline \multicolumn{7}{|c|}{ Oil and Oily watcr } \\
\hline $2101-U$ & $<0.15$ & 1.29 & udl & $120-21,000$ & $2-26$ & NA \\
\hline Tank & $\begin{array}{l}\text { Total U } \\
(\mathrm{mg} / \mathrm{L})\end{array}$ & $\%{ }^{235} \mathrm{U}$ & $\begin{array}{c}\text { PCBs } \\
(\mathrm{mg} / \mathrm{L})\end{array}$ & $\begin{array}{c}\text { Oil and grease } \\
\text { (mg/L) }\end{array}$ & $\begin{array}{c}\text { Total Hg } \\
(\mathrm{mg} / \mathrm{L})\end{array}$ & $\begin{array}{l}\text { Other } \\
(\mathrm{mg} / \mathrm{L})\end{array}$ \\
\hline $2100-U$ and $2101-U$ & $2.0-21.0$ & $0.80-1.65$ & udl-6.3 & NA & $740-29,000$ & NA \\
\hline 2104-U & $9.9 \mathrm{mg} / \mathrm{L}-0.04 \mathrm{~g} / \mathrm{g}$ & $0.20-0.67$ & udl-120 & NA & $2-330$ & $\begin{array}{c}\mathrm{Pb}(10.6) \\
\text { Cresol (udl-583) }\end{array}$ \\
\hline
\end{tabular}


Analysis of the water in the tanks before filtration into a tanker showed mercury at levels as high as $150 \mathrm{mg} / \mathrm{L}$, nickel at $58 \mathrm{mg} / \mathrm{L}$, copper at $69.3 \mathrm{mg} / \mathrm{L}$, and PCBs at less than $0.5 \mathrm{mg} / \mathrm{L}$. WTO was able to treat the water within the permitted treatment capabilities and determined the effluent water would be well below mercury monitoring limits. Therefore, Waste Management and WTO agreed to accept the water and directed the project manager to filter the water prior to pumping it into a transport vessel (a tanker or a polytank) to remove suspended solids. MK-F filtered all waste water through a 50-micron filter and 10-micron filter before it was pumped into transport vessels. Filled transport vessels were moved by Waste Management and WTSD to the full lot, and the water was sampled. Once the completed analysis was received, the material was transported to the treatment location.

Waste water from the mercury settling tanks was sent to the West End Treatment Facility (WETF) or the Central Pollution Control Facility (CPCF).

The WETF is designed to treat nitrate-bearing aqueous wastes from Y-12 production operations. The waste streams treated at the WETF consist of nitric acid wastes, rinse waters, groundwaters, mixed acid wastes, waste coolants, mop waters, and caustic waters. Effluent from the WETF is discharged through an National Pollutant Discharge Elimination System (NPDES) permit, Serial Number Discharge 502, into East Fork Poplar Creek.

The CPCF is designed to treat mop waters and non-nitrate-bearing aqueous waste streams. The waste waters to be treated are categorized as dilute waste water or mop waters, acidic waste, caustic wastes, and plating rinse waters. These general categories of wastes cover a broad range of chemical compositions and concentrations and may include significant quantities of heavy metals, acids, and bases. Effluent from the CPCF is discharged through an NPDES permit, Serial Number Discharge 501, into East Fork Poplar Creek.

In addition to the waste water removed from the tanks, project activities also generated decontamination and shower waste water. These wastes were stored in polytanks supplied by WTSD and located in the staging area. WTSD later transported the polytanks to the appropriate Y-12 Plant waste water treatment facility.

The oil and oily water from Tank $2101-\mathrm{U}$ were placed in polytanks and stored at the Y-12 Plant for eventual incineration at the K-1435 Incinerator.

Basic data about waste water are presented in Table 3.

Sludge. Sludge handling procedures were described in the project best management practices plan and the project inspection plan. The best management practices plan originally called for the drums to be dewatered, but WTSD agreed to accept sludge that had not been completely dewatered. The inspection p!an required that a percentage of the drums be inspected for dryness prior to shipping them off the work site, but this requirement also became unnecessary once WTSD revised its waste acceptance guidelines.

Sludge that was removed from the tanks was drummed and held in the staging area. Waste drum inspections were conducted to verify that the drums met long-term storage requirements. The drums containing sludge from tanks $2100-\mathrm{U}$ and $2101-\mathrm{U}$ were moved into 
Table 3. Quantities of wastes generated during the mercury tank cleanout

\begin{tabular}{|c|c|c|c|c|}
\hline Tank & $\begin{array}{l}\text { No. of } \\
\text { containers }\end{array}$ & $\begin{array}{c}\text { Volume } \\
\text { (gal) }\end{array}$ & $\begin{array}{l}\text { Weight } \\
\text { (lb) }\end{array}$ & Classification \\
\hline \multicolumn{5}{|c|}{ Sludge } \\
\hline $2100-U$ and $2101-U$ & 149 drums & 7,450 & 67,050 & RCRA \\
\hline 2104-U & 17 drums & 850 & 5,460 & TSCA \\
\hline \multicolumn{5}{|c|}{ Waste water } \\
\hline $2100-U$ & 0 & 0 & 0 & NA \\
\hline 2104-U & 4 tanker trucks & 20,000 & 160,000 & RCRA \\
\hline \multicolumn{5}{|c|}{ Oil and oily water } \\
\hline $2101-U$ & 5 polytanks & 1,575 & 12,600 & RCRA \\
\hline \multicolumn{5}{|c|}{ Personal protective equipment } \\
\hline $2100-U$ and $2101-U$ & 59 drums & 3,600 & 1,200 & $\mathrm{RCRA}^{a}$ \\
\hline 2104-U & 14 drums & 700 & 1,400 & $\mathrm{TSCA}^{a}$ \\
\hline
\end{tabular}

aPPE waste was classified according to the characterization tests of the sludge from the tank at which the PPE was used.

long-term storage at the K-25 Site. The sludge from Tank 2104-U was contaminated with PCBs and was managed as Toxic Substances Control Act (TSCA) waste. Basic data about these drums of sludge are presented in Table 3.

Personal protective equipment. PPE wastes were drummed and stored at the work zone. PPE waste was characterized by the characterization parameters of the sludge from the tank at which the PPE was used. The drums containing PPE were later moved into long-term storage at the K-25 Site. Basic data about PPE waste are presented in Table 3.

\section{FINAL INSPECTION}

Inspections for cleanliness and the current condition of the tanks were conducted individually for each tank after the material had been removed. C. E. May, Energy Systems construction engineer, completed the cleanliness inspections and signed the reports certifying that they had been cleaned to IROD requirements. John W. Harris of Energy Systems ET\&I Division completed the visual inspection of the tanks for their current condition. He and his supervisor, Richard S. Sampson (also of Energy Systems ET\&I Division), signed the reports certifying what they had found. These inspections are described in greater detail in Sects. 3.1 and 4.1. Dates of the inspections are provided in Sect. 2. 


\section{CERTIFICATION THAT THE REMEDY IS OPERATIONAL AND FUNCTIONAL}

This project is considered to have been completed successfully because it met its performance objectives as addressed in the IROD and the work plan: to remove the waste from the three storage tanks; to ensure that the tanks were cleaned to the levels specified; to return tanks $2100-\mathrm{U}$ and $2104-\mathrm{U}$ to service; to isolate Tank 2101-U permanently; and to manage the wastes in an appropriate fashion.

The work plan required that an independent professional engineer conduct the final inspection to certify that all work was done according to project requirements. However, after removal activities were completed, DOE informed Energy Systems that independent verification was not required for this CERCLA action as long as the site remains the responsibility of DOE.

Samples were taken at the tank inlet and outlet flows of tanks 2104-U and 2100-U to provide a baseline for future monitoring (Table 4). Tank 2101-U was not sampled because it has been abandoned in place and no longer contributes water to the storm sewer system.

Table 4. Results of water sampling data from samples taken after interim removal action

\begin{tabular}{lcccccc}
\hline $\begin{array}{c}\text { Sample } \\
\text { location }^{a}\end{array}$ & $\begin{array}{c}\mathrm{Hg} \\
(\mathrm{mg} / \mathrm{L})\end{array}$ & $\begin{array}{c}\mathrm{PCBs} \\
(\mathrm{mg} / \mathrm{L})\end{array}$ & $\begin{array}{c}\text { Total } \mathrm{C} \\
(\mathrm{mg} / \mathrm{L})\end{array}$ & $\begin{array}{c}\text { \% U235 } \\
(\% \text { by weight })\end{array}$ & $\begin{array}{c}\text { Gross } \alpha \\
(\mathrm{pCi} / \mathrm{L})^{b}\end{array}$ & $\begin{array}{c}\text { Gross } \beta \\
(\mathrm{pCi} / \mathrm{L})^{b}\end{array}$ \\
\hline \multirow{7}{*}{ Tank 2100-U } \\
Inlet & 0.089 & $<0.0005$ & 0.003 & 0.81 & $0.43 \pm 6.1$ & $-0.33 \pm 5.4$ \\
Outlet & 0.086 & $<0.0005$ & 0.003 & 0.85 & $6.9 \pm 7.5$ & $2.5 \pm 5.7$
\end{tabular}

Tank 2104U

\begin{tabular}{lllllll} 
Inlet & 0.0015 & $<0.0005$ & 0.007 & 0.27 & $-3.7 \pm 4.8$ & $-1.6 \pm 5.2$ \\
Outlet & 0.0025 & $<0.0005$ & 0.008 & 0.21 & $5.8 \pm 7.0$ & $1.1 \pm 5.5$ \\
\hline
\end{tabular}

${ }^{b}$ Relative to normal background levels, with range of variance.

\section{OPERATION AND MAINTENANCE}

The interim remedial action removed the mercury-contaminated sludges and liquids from the three tanks. Tank $2101-U$ has been abandoned in place. Tanks $2100-U$ and $2104-U$ have been returned to service as part of the storm water sewer system and continue to be used to set:le sludges in water pumped from building 9201-4 and 9201-5. Thus sludges will continue 
to accumulate in these tanks, necessitating a 5-year review of the interim response action. Sludge volumes in tanks $2100-\mathrm{U}$ and $2104-\mathrm{U}$ will be monitored to determine the rate of sludge accumulation in each tank. The water in the tanks will be characterized periodically to determine what levels of contamination the tanks may be contributing to UEFPC. These observations will be used to determine a schedule for periodic removal of sludge for the tanks in accordance with operation and maintenance requirements under CERCLA.

\section{SUMMARY OF PROJECT COSTS}

The projected cost identified in the remedial action work plan was $\$ 850,000$. This amount was budgeted under DOE Activity Data Sheet 2303 to cover all contingencies for this interim action. Actual costs for this project were $\$ 1,107,590$. Project costs broke down as follows:

Radian [development of work plan (Radian 1992)]

$\$ 197,000$

Energy Systems (integrating contracting, project

$\$ 153,433$

management, and Title III and construction support)

$\$ 820,157$

MK-Ferguson (construction management and direct-hire construction) 


\section{REFERENCES}

Radian Corporation. 1992. Remedial Action Work Plan: Interim Action for the Y.12 Plant Mercury Tanks. DOE/OR-1039\&D2. Radian Corporation, Oak Ridge, Tennessee.

Radian Corporation. 1991. Record of Decisiom Interim Action for the Mercury Tank Remediation. OKR/MI-(1)5s. Rialian Corporation, Oak Ridge. Tennessee.

Van Ryn, F. R. 1991. Interim Actiom Propossed Plan: Mercury Tank Remediation at the Oak Ridge Y.12 Plant, Oak Ridg'c, Tenne'sis'c. ES/ER.21 \&D.3, Martin Marietta Energy Systems, Inc., Oak Ridge, Tennessee. 
Appendix $\mathrm{A}$

CERTIFIED-FOR-CONSTRUCTION PACKAGE (TECHNICAL SPECIFICATIONS) 
A-3

Contents

Date: November 9, 1992

TECHNICAL PROVISIONS

CONTENTS

\begin{tabular}{ll} 
DIVISION & DESCRIPIION \\
DIVISION 1 & SPECIFIC SUBCONTRACT REQUIREMENTS \\
DIVISION 2 & NOT USED \\
DIVISION 3 & NOT USED \\
DIVISION 4 & NOT USED \\
DIVISION 5 & NOT USED \\
DIVISION 6 & NOT USED \\
DIVISION 7 & NOT USED \\
DIVISION 8 & NOT USED \\
DIVISION 9 & NOT USED \\
DIVISION 10 & NOT USED \\
DIVISION 11 & NOT USED \\
DIVISION 12 & NOT USED \\
DIVISION 13 & NOT USED \\
DIVISION 14 & NOT USED \\
DIVISION $15 \mathrm{~A}$ & NOT USED \\
DIVISION $15 B$ & NOT USED \\
DIVISION 16 & NOT USED \\
DIVISION 17 & NOT USED \\
\hline
\end{tabular}

REMEOIAL ACTION WORK PLAN

INTERIM ACTION FOR THE Y.12 PLANT MERCURY TANKS

(DOE/OR-10398D2)

$240 . M$ 
A.5

Date: November 9, 1992

\section{DIVISION 1}

SPECIFIC SUBCONTRACT REQUIREMENTS INDEX

\begin{tabular}{llr}
\hline Number & \multicolumn{1}{c}{ TItTe } & $\begin{array}{c}\text { No. of } \\
\text { pages }\end{array}$ \\
\hline 01010 & SUMMARY OF WORK & 7 \\
01110 & SAFETY AND HEALTH & 3 \\
01160 & CONFINED SPACE ENTRY AND WORK & 12 \\
01170 & CARCINOGEN CONTROL & 13 \\
01180 & RESPIRATORY PROTECTION & 6 \\
01190 & LOCKOUT/TAGOUT & 5 \\
01500 & CONSTRUCTION FACILITIES ANO TEMPORARY & 4 \\
& CONTROLS & \\
& INSPECTION PLAN (Y/EN-4788) &
\end{tabular}

$240 . M$ 
SECTION 01010

SUMMARY OF WORK

PART 1 - GENERAL

1.01 DESCRIPTION

A. Location of Work

The work is located in the Y-12 Plant, aovernment-owned factlity, managed by Mart in Marietta Energy Systems, Inc., for the Department of Energy (DOE), in Oak Ridge. Anderson County, Tennessee.

B. Scope of Work

The work described in this specification consists of furnishing labor, materials, tools, equipment, and services (except that specified to be furnished or parformed by others) required to remove oll, olly water, waste water, and sediments from three underground concrete settiing tanks: $2100-U, 2101-U$, and $2104-U$, complete and in strict accordance with this specification, drawings, and all the other provisions of the subcontract.

\subsection{SECURITY}

A. Clearance Requirements

Work requires "Q"-cleared personnel or uncleared personnel with Contractor-provided "Q"-cleared escorts.

B. Escort Requirements

1) Escorts shall have an active DOE "Q" clearance and Construction Manager provided security orientation.

2) Escorts shall be nonworking personnel and cannot perform construction activities.

3) An escort cannot escort more than five uncleared personnel. Additional escorts may be required depending on the work location, method of accomplishment, and access to the job site. Uncleared personnel shall remain within sight of an escort whan in secured area. 
1.03 FACILITIES MANAGER INTERFACE

Throughout the technical specifications and drawings, the term Facilities Manager (FM) is utilized. It is defined as Energy Systems, acting under contract to DOE.

The FM will ensure construction is in accordance with the spectfied requirements (Title III Verification Activities), coordinates interface between plant operations and construction activities, and ensures operational health, safety, and environmental requirements are met.

The FM's Title III representative will participate in testing, inspections, and recelpt and approval of required submittal data. Destgnated tests and inspections shall be performed in a manner that allows observation by both the Construction Manager's Construction Engineer and the FM's Title III representative.

All communications between the Contractor and FM shall be through the Construction Manager.

\subsection{SPECIFICATIONS AND DRAWINGS}

A. Spectifications

The work shall conform to the subcontract specifications listed in the table of contents and each subsequent division index.

B. Drawings

The work located on Drawings C2E900000A804 and P2E900000SK19.

C. Terminology

The following definitions provide clariftcation of terms that are found in the specifications Divs. 2-17 and on the drawings:

1) Construction Manager may also be reforred to as the Company, Contracting officer, or Construction Engineer.

2) The Contractor may also be reforred to as the Subcontractor.

3) The FM may also be reforred to as the Operator, Energy Systems, or MM-ES.

1.05 WORKING AND STORAGE AREAS

Limit construction activities and storage to the area designated on Drawing C2E900000A804. Personnel shall enter and extt the plant through Portal 33. Limit travel to the main roads designated on the drawings. The contractor is responsible for providing detalled instructions outlining the work area restrictions to its personnel and keoping its personne within authorized iimits. The FM's Plant Protection Department 
A.9

will remove personnel from the plant when found outside the designated areas.

1.06 PROJECT COORDINATION

A. The construction work area will be vacated during construction and will not be reoccupied until acceptance of beneficial occupancy.

B. Submit requests for outages a minimum of $8 \mathrm{~d}$ in advance of needed date. The Construction Manager will coordinate outages with the FM and provide an approved outage schedule. Outages shall be held to a minimum in number and duration.

C. Notify the Construction Manager at least $24 \mathrm{~h}$ before performing specified tests and inspections. Tests and inspections shall be performed in a manner that allows observation by both the Construction Manager and FM.

\subsection{SUBMITTALS}

A. Submittals are identified in the specifications and on the drawings. Six coples are required for Item B, and nine coples are required for Item $C$ below. However, if a larger number of coples is specifically identified in the specifications or on the drawings, the larger number of copies shall be submitted.

B. Submittals identified as Approval, For Approvel, and For Roviow require written approval before defivery of the material or equipment to the job stte. This requirement also applies to "or equal" requests.

C. Submittals identified as Certifled, For Record, After Approval, Approved, and For Information require one-time submittal when the equipment or material is delivered to the job site. A written response is not required by the Construction Manager or FM.

D. Direct Hire Work

For all direct hire work performed by M-K Ferguson, submittals are not required for items where M-K Ferguson maintains records. Examples are medical exams, respirator fit test, training, weld procedures, work plans, welder qualification, hazardous inventory, independent test laboratory certification, monitoring, and entry-exit logs. In lieu of these submittals, the Construction Manager shall provide a 1ist to the FM of all items where records are maintained. This ilst shall include names of personnel performing work along with their qualifications.

1.08 REVIEW OF SHOP DRAWINGS, PRODUCT DATA, AND SAMPLES

Information submitted for approval in accordance with the subcontract General Conditions Article GC25 will be returned to the Contractor within 20 calendar days of receipt of the submittal by the Construction Manager. 
1.09 DELIVERY, STORAGE, AND HANDLING ${ }^{\mathrm{A}-10}$

A. The Contractor shall comply with instructions, recommendations, or requirements stated by the manufacturer or in the specifications for handling and storing of all items.

B. All items delivered to the site shall be identified with a weather-resistant tag or label. The tag or label shall have the following information:

1) Contractor's name, job title, and contract number.

2) Identify the internal contents for items in containers, boxes, or crates.

3) State indoor storage or heated indoor storage, if required.

c. With multiple items shipped, identify each container, box, or crate with a unique number and indicate the total tems shipped. (Example: 1 of 4,2 of 4 , etc.).

D. Operators required to handle special handling or lifting equipment shall be trained or experienced in using the equipment.

1.10 UNUSUAL CONDITIONS

Submit request for tank alterations a minimum of $14 \mathrm{~d}$ in advance of needed date. The Construction Manager will coordinate alterations with the FM and provide an approved design.

PART 2 - PRODUCTS

2.01 PROPERTY TO BE FURNISHED BY THE CONSTRUCTION MANAGER

A. The Construction Manager will procure and provide the following material and equipment to the contractor:

1) Saranex Coverall with Hood, Elastic Wrists and Ankles

15 case - Hazmat DC120SARXL

15 case - Hazmat DC120SARXXL

2) Butyl Rubber Gloves

250 pair - Hazmat B161-10

3) Surgical Gloves

1,000 pair - Hazmat B7005

4) Cotton Inspectors Gloves

84 dozen pair - Hazmat GLI58 - 
5) Rubber Boots

24 pair - Hazmat LAT1250

6) Respirator Wipes - Nonalcoholic

5 each - MSA CT-943

7) 18-in. White Plastic Squeegee

4 each - Hazmat 230ASB18

8) 54-in. Wood Handle for Squeegee

4 each - Hazmat 221ASB

9) First Aid Kit

1 each - Hazmat FA25

10) Respirator Storage Bag

250 each - Hazmat $61.1812 \times 12$

11) MSA Air Supply System

4 each - MSA 496896

12) MSA Air Hose Assembly

8 each - MSA 455022

13) MSA 4 Outlet Manifold

1 each - MSA 93931

14) MSA Quick Release Connections

8 each - MSA 455019

15) MSA Socket Connections

8 each - MSA 476956

16) MSA Female Plug

8 each - MSA 479026

17) MSA Snaptite Fittings

8 each - MSA 66274 
18) MSA Union Adapters

8 each - MSA 69542

19) SCBA Units, 30-min. Air Supply With Case

2 each - MSA 801373

20) VERI-Clear Personal Communication System

3 each - MSA 474500

21) Shure-Hold Confined Snace Retrieval Protection System Kit

2 each - MSA 696540

22) Miscellaneous Electrical Materials for Temporary Facilities

23) Miscellaneous Lumber and Fireproof Plastic for Temporary Facilities

24) Portable Field Office

1 each - Knaack Model 119

25) PCB Contaminated 0il Transfer Pump

1 each - McMaster-Carr 9923K15 or equal (Catalog No. 98, p. 1323),

26) Wire Reinforced PVC Tubing, $11 / 4$ in. ID $\times 13 / 4$ in. OD

100 feet - McMaster-Carr 5393K37 or equal

27) 1 1/2-in. Heavy-Duty Suction/Discharge Hose for MEGA Pump

125 feet - McMaster-Carr 5651K49 (50 ft) and 5651K45 (25 ft)

28) Storage Trailer

1 each Wells Cargo WW1611

29) 20-mil PVC Flexible Membrane Liner for Secondary Containment $3,420 \mathrm{ft}^{2}$ at $50.20 / \mathrm{ft}^{2}$ 
30) GE Portable VHF Radio for MSA VEA T $^{3}$-Clear Personal Communication System 2 each - GE Model MPI 4H3

31) I each - Mega Pump Abatement TEC Nologies Model S5500 and Filters

32) 150 each - Environmental Scientific, Inc., Model 17H Drum Pad

33) 150 each - Drum caps

34) 1 each - Drum pump Sethco Pump Model P8OH-40 (DS-EM-900000-A001)

35) 2 each - Low-flow air-monitoring pumps

36) 2 each - Passport Model LEL/O $\mathrm{O}_{2}$ meters with calibration kit.

B. The Construction Manager will be provided the following FM-supplied material and equipment:

1) all respirators and respirator cartridges;

2) all storage drums, liners, polytanks, tuff tanks, and tanker trucks; and

3) Jerome Mercury Vapor Analyzer and sample analyses of collection media of the low-flow air-monitoring pump.

c. Material and equipment will be delivered to the job site by the Construction Manager.

PART 3 - EXECUTION

3.01 PREPARATION

General Employee Training

The Construction Manager will provide an 8-h general employee training program for Contractor personnel. This training is mandatory for all personnel and requires passing a written examination prior to working at any DOE Oak Ridge site. Annual training and reexamination is required.

END OF SECTION 
SECTION 01110

SAFETY AND HEALTH

PART 1 - GENERAL

1.01 EVACUATION OF THE WORK AREA

A. The Contractor shall observe and participate in notices to evacuate the work area. The evacuation notices may be a drill or an actual event.

B. Before evacuating the work area, shut down or make safe equipment or processes which could become a safety or fire hazard if left unattended.

1.02 SAFETY AND HEALTH WORK REQUIREMENT CHECKLIST

The Contractor shall submit a request for the Safety and Health Requirement Checklist $5 \mathrm{~d}$ before starting on-site work. The checklist is required before starting on-site work and for preconstruction inspections requiring site access. Post the checklist at the job site. The Construction Manager's Construction Work Release may be posted at the job site in lieu of the checklist if all requirements of the checklist are included.

\subsection{HAZARDOUS WORK REQUIREMENTS}

A. Radioactive and chemical contamination, carcinogen control, and confined space entry are hazardous items present on this project.

The following sections address the requirements for each hazard.

a. Section 01160 - Confined Space Entry and Work.

b. Section 01170 - Carcinogen Control.

B. Asbestos and nonasbestos fibrous insulation are hazards NOT expected on this project. However, if these hazards are encountered during construction, the Contractor shall stop work on all hazardous work activities and notify the Construction Manager. The Construction Manager will evaluate the job site conditions and either issue additional requirements necessary to perform the hazardous work or will delete the hazardous work from the project. 


\subsection{HAZARD MATERIAL COMMUNICATION}

A. The Contractor shall complete a hazardous material inventory report that identifies hazardous materials brought on-site. Obtain the report forms from the Construction Manager. The hazardous materials identified shall be those stated in 40 CFR Part 355, 29 CFR 1910.120, and any material which there is an uncertainty of the hazard potential. If no known hazardous material will be brought on-site, the Contractor shall state "None" on the form.

B. Pursuant to the Occupational Safety and Health Act's Hazard Communication Standard for construction, the following hazardous substances are present on this work site: mercury, polychlorinated biphenyls (PCBs), and radiological contamination.

C. The Construction Manager will provide training information for PCBs and mercury.

\subsection{PROTECTION OF THE WORK AREA}

A. Furnish, post, erect, and install safety devices, equipment, signs, barricades, flagging, and any other item necessary to protect personnel having access to the area.

B. The job site, storage areas, and hazardous work areas shall be conspicuously flagged or barricaded.

1.06 WORKING NEAR ELECTRICAL LINES

Cranes, bucket trucks, or aerial lifts, not approved for electrical work, shall not be permitted to come within $15 \mathrm{ft}$ of $100 \mathrm{~V}$ or greater electrical power lines.

1.07 TRANSPORT VEHICLES FOR FLAMMABLES

All flammable liquid tank trucks, Contractor-owned refueling vehicles, and all other vehicles transporting flammable liquids or gases will be inspected by the Construction Manager with assistance from the Facilities Manager's (FM) fire department and may require FM escort while on Government property.

\subsection{VEHICLE CONTAMINATION SURVEYS}

All vehicles are subject to inspection for contamination when both entering and exiting the Plant. Inspections will be made at the access portal. 


\subsection{ON-SITE SAFETY INSPECTION}

The safety, health, fire, and environmental protection personnel of the Construction Manager, Government, and FM will inspect the Contractor's facilities and operations at the job site to ensure compliance with the hazardous communications, safety, health, fire prevention, and environmental protection requirements of the subcontract. All communication, except in cases of imminent danger, will be through the Construction Manager to the Contractor.

PART 2 - PRODUCTS

Not used.

PART 3 - EXECUTION

Not used.

END OF SECTION 
PART 1 - GENERAL

\subsection{DESCRIPTION}

A. This section provides requirements for construction work in areas containing radioactive contamination. The work area is classified as a controlled area, and airborne radoactivity is not present.

B. The entrance to the tanks are located in a controlled area. The tanks, themselves, are a contamination area; and Tank 2104-U may be classified as a radiation area subject to survey results.

c. Definitions

1) Airborne Radioactivity Aroa: Any area where airborne radioactive concentrations are greater than one-tenth of the derived air concentration.

2) Contamination Area: An area where surface contamination is 10 times in excess of Department of Energy (DOE) standards for unrestricted use but less than 100 times the standard.

3) Derived Air Concontration: Quantity obtained by dividing the annual limit on intake for any given radionuclide by the volume of air breathed by an average worker during a working year.

4) High Contamination Area: An area where surface contamination is in excess of 100 times the DOE standards for unrestricted use.

5) Radiation Work Pormit (RUP): A permit, needed in areas identifled above, is used to maintain the radiological exposure of personnel as low as reasonably achievable through control of work at the job site when significant radiation exposure potential exists.

6) Regulated Area: An area where surface contamination is in excess of DOE standards for unrestricted use but not greater than ten times the standard.

7) Surface Contamination: Unwanted radioactive material which is deposited on the surfaces of structures, areas, objects, or personnel. 
1.02 RELATED WORK

Section 01180, Respiratory Protection.

1.03 REFERENCES

American Standard for Testing and Materials (ASTM) $0.2986-91$, Standard Practice for Evaluation of Air Assay Madia by the Monodisperse DOP (Dioctyl Phthalate) Smoke Test.

1.04 SUBMITTALS

A. Trained Personnel: Provide a 11 st of training recelved by all personnel. State the employee's full name, job title, title of course(s). training date, and training organization. Include a copy of the training certification(s).

B. Medical Examinations: Submit a list of employees receiving the required medical examinations. Include the employee's full name, social security number, and date of most recent examination.

C. Leak Test Results: Submit coples of the in-place leak tests performad by an independent testing laboratory for all high-offletency particulate air (HEPA) filter systems.

1.05 UELIVERY, STORAGE, ANO HANDLING

A. Waste Disposal: Dispose of contaninated waste in metal B.25 storage boxes (approximately $4 \mathrm{ft} \times 6 \mathrm{ft} \times \& \mathrm{ft}$ ). Boxes will located at the contaninated work site.

If the B-25 boxes cannot be located within the contaminated work site;, waste shall be wrapped or bagged before moving it from the contamination area to the boxes. A permit is required before waste can be ramoved from the contaminated area to the boxes. Notify the Construction Manager $10 \mathrm{~d}$ in advance of the need for the permit.

B. Tools and Equipment: Tools and equipment, including power equipment and temporary scaffolding, shall remain within the contaminated area unt 11 checked for contamination and tagged for removal. Contaminated tems will be decontaminated and returned to the contractor. 
PART 2 - PROOUCTS

\subsection{EQUIPMENT}

A. Factlities Manager-Furnished Equipmant

The Factlittes Manager (FM) will furntsh the following equipant to the Contractor. All requests for this equipanent shall be through the Construction Manager.

1) Underwear, coveralls, socks, gloves, shoe covers, and all other protective clothing needed to work in contaninated areas.

2) Respirators and cartridges.

3) Radiation dosimoters.

4) Personnel monttoring station and all equipment necessary to perform required monttoring.

8. Contractor-Furnished Equipment

The Contractor shall provide the following equipment:

1) Safoty shoes with clearly marked yellow toes for work in contaminated areas. These shoes cannot leave the contaminated area until decontaminated.

2) Vacuum cleanars equipped with HEPA fllters.

3) Portable electric hand tools, equipped with HEPA filters.

4) All HEPA filters for Items 2 and 3 above. These fllters shall providb an efficlency of not less that $99.97 \%$ when challenged with 0.30 -micrometer particle size ierosol.

C. Change Factilties

1) The Contractor shall provide the change facllitios.

2) The change facllitles will include clean/dirty chango areas, shower factlities, lockers, and storage for clean/dirty protective clothing.

3) Instructions regarding the proper use of the designated change facllity wlll be provided during Radiation Worker Training. 
PART 3 - EXECUTION

\subsection{PREPARATION}

A. Radiation Worker Training

1) Personnel shall complete Radiation Worker Training and pass a written examination. Oral exaninations are not perwitted. Training will include an $8 \cdot h$ radiction, $2 \cdot h$ monttoring, and $2 \cdot h$ dress-out program. Retraining is required every 2 years.

2) Schedule training, with the Construction Manager, at least $14 d$ in advance.

8. Hazardous Waste Stle training

Personnel shall complete the Hazardous Waste Operations and Emergency Response Training as spectified in 29 CFR 1810.120, para. (e).

C. Medical Survelliance

Provide a physictan's certificate stating the employes has received a madical examination: and in the phystctan's opinton, the omployee is physically fit to work while using a respiretor. The physictan's certificate becomes invalid 12 months after date of 1ssue. and aw certificate is required.

D. Modical Monitoring

1) Before starting on-slte work, bloassay (urine analysis) and invivo (body) monitoring is raquired. Schedule medical monitoring at least 5 in advance. Monttoring will require $4 \mathrm{~h}$ per employee.

2) The Contractor will be issued radiation dosimater identification badges before the start of on-site work. The dosimeter badges shall be worn at ill times while on-site.

E. Ares Classification

The work site will be classifled as either Requlated. Contamination, or High Contamination Ares. Before the Contractor starts on-site work. boundaries will be established, barriers in place, and appropriate sions posted. Notify the Construction Manager if the ares is not classified.

F. Radiation Work Permit

The coneractor shall request the issuance of an RWP at least 5 d before the scheduled work octivity. An approved RWP shall be issued and posted at the project site before a Contractor is permited to onter the radiologically contaminated area. 
G. Equipuent Testing

Equipment brought on-site having a HEPA fllter shall be tested before use and HEPA filter replacoment requires ratesting. The Contractor shall have in independent testing laboratory perform a test on the equipment in accordance with ASTM D-2986. The testing laboratory shall provide written certification that the MEPA filtration system is properly operating. Submittal of the certification document is required before using the equipment.

\subsection{INSTALLATION/APPLICATION/ERECTION}

A. Facillities Manager Services

All request for FM services shall be scheduled through the Construction Manager. The FM will provide the following services:

1) Laundry service for protective clothing and cleaning service for resotritors.

2) Radiation worker training $(12 \mathrm{~h})$.

3) Bloassay and invivo monitoring. This service is requitred of employees before starting work, monthly during construction, and on complotion of the last day. Each monitoring activity requites $4 \mathrm{~h}$.

1) RPW.

5) Permits for romoval of waste, contractor's tools, and equipment.

6) Decontamination services for tools, equipment, and personnel.

7) Matal 8.25 storage boxes for disposal of contaminated waste.

8) Personnel exposure records.

9) Air monitoring (if required).

B. High Contamination Area

Do not enter a work ares that has boen classifled and posted as a High Contamination Aras.

C. Regulated Ares Requirements

1) The Contractor shall reviow all potential radiological hazards with all personnel working in the regulated ares.

2) The Contractor shall maintain a log of all personnel entering the regulated ares. If required by the RUP, enter the entry and exit time every time a person enters or leaves the ores. 


\section{A.24}

3) No cating, drinking, use of tobacco, or chewing gum is allowed.

4) Enter only to perform required work.

5) Personnel monitoring is required before leaving the area.

6) No personal items are permitted.

D. Levels of Personal Protective Equipment

The Construction Manager's Stte Safoty and Health Officer will dotermine the PPE needud for each task and wtll cont inuously monltor work conditions to determine if modification is needed. Levels of protection shall be based upon the Remedial Action Work Plan.

E. Containment of Dust and Dabris

The following are requirements for all contaminated work areas.

1) Equip portable hand tools used to drill, cut, or otherwise disturb contaminated materials with a HEPA-flltered exhaust ventilation system.

2) Always implement dust-suppression techntques. Ory sweeping, using compressed atr for cleaning, or other dust-creating activitios are prohibited.

3) All HEPA fllters and respirator cartridges shall be discarded as contaminated waste.

\section{F. Personnel Montioring}

1) Each worker exiting a rogulated or contamination area into a less restrictive ares shall be self-monitored. Monitoring requirements will be provided during the Radiation Monitoring Training program. Follow posted instructions and ut 11120 the equipment provided.

2) Upon exit from a contamination area, whole body frisk is required (estimated time is $8 \mathrm{~min}$ ).

3) Upon exit from a ragulated area, hand and foot frisk is required (estimated time is $4 \mathrm{~min}$ ).

4) Contamination is not expected to be found during monitoring. If contamination is found, remain at the monitoring station and call the Construction Manager. Decontamination must be completed before the worker leaves the monitoring station. 
G. Respiratory Protection

Respiratory protection is required for all work in the contaminated area. All resptratory protection shall be in accordance to sect. 01180, Respiratory Protection and in accordance with the Remedial Action Work Plan.

3.03 FIELD QUALITY CONTROL

\section{Personnel Exposure Records}

The Contractor is responsible for maintaining personnel exposure records for his employees. The personnel exposure records for this work will be supplied to the contractor, and it shall be the responsibility of the contractor to provide the information to his employees.

\subsection{PROTECTION}

To finish the madical monitoring, the Contractor shall arrange for a bioassay and invivo analysis of personnel upon complation of all project work or before an employee's work is fintshed. Coples of personnel exposure records will be provided to the contractor by the construction Manager when medical monitoring is complete for the project.

END OF SECTION 
SECTION 01160

CONFINED SPACE ENTRY AND WORK

\section{PART I GENERAL}

\subsection{DESCRIPTION}

A. This section provides construction requirements to control access into and work within all confined spaces. Work shall be in accordance with American National Standard Institute (ANSI) Safety Requirements for Confined Spaces Standard 2117.1-1989, Occupational Safety and Health Act (OSHA) Standard 29 CFR 1926, and additional requirements stated in this section. The contractor is responsible for determining the most recent confined space requirements established by federal, state, and local government regulations. If conflicts exist between applicable requirements and this section, the most stringent provistons apply.

B. Existing Confined Spaces

Based on the existing site conditions for this project, the Facilities Manager (FM) has initially classified the following space(s):

Hioh Risk

Concrete Settling Tanks $2100-U, 2104-U$, and 2101-U.

C. Confined Space Identification and Permit

1) For all confined or potential confined space(s), the Contractor shall complete Part 1 of the Confined Space Entry/Work Permit, Attachment 1 , and submit it to the Construction Manager for determination if the area is a confined space. Immediately before entry, the Construction Manager will perform atmospheric tests. The results of the tests and evaluation will be recorded on Part 2 of the permit, approved and issued to the Contractor.

2) The Contractor shall identify all potential confined spaces created by construction activities and submit a permit.

3) All excavations over $4 \mathrm{ft}$ in depth shall be considered a potential confined space and requires the submittal of a permit. 
D. Definitions

The following definitions are in addition to those provided in ANS1 2117.1:

1) Autherized Attendant - A qualified person whose sole work assignment is to monitor and react as necessary to support the entrants' activities within the confined space.

2) Confined Space - An enclosed area that has all the following characteristics:

a. Its primary function is something other than human occupancy.

b. It has restricted entry and exit.

c. It contains potential or known hazards.

Examples of confined spaces include but are not 11 imited to: tanks, s1los, vessels, pits, sewers, pipelines, bollers, ut lifty vaults, and may include excavations greater than $4 \mathrm{ft}$ in depth.

3) Entry - Ingress into and/or work within a confined space including breaking the plane of the confined space opening with any part of the body.

4) Hiah Risk Confined Soace Entry - an entry/work in a confined space presenting a high potential for death, disablement, injury, or acute iliness from one or more of the following:

a. A flammable gas, vapor, or mist in excess of $10 \%$ of its lower explosive limit;

b. An oxygen deficient atmosphere containing less than $19.5 \%$ oxygen by volume or an oxygen enriched atmosphere containing more than $23.5 \%$ oxygen by volume;

c. An atmosphere concentration of a substance listed in Subpart 2 of 29 CFR 1910 OSHA Standard above the listed numerical value of the permissible exposure limit or above the listed numerical value of the Threshold Limit Value (TLV) published by the American Conference of Governmental Industrial Hygientsts;

d. A condition recognized as immediately dangerous to life or health (IDLH);

e. An environment containing material that may engulf an entrant;

f. An internal configuration that may trap an entrant such as inwardly converging walls or a floor which slope downward and tapers to a smaller cross-section: 
g. Health hazards such as excessive noise, heal stress, nonionizing radiation, and operating steam lines;

h. Use of compressed gas (other than breathing grade air), solvents, or heat-producing processes such as welding, soldering, or grinding.

i. Ionizing radiation levels meeting one of the following:

(1) A dose equivalent of $100 \mathrm{mrem} / \mathrm{h}$ or above for an external exposure hazard.

(2) Airborne radioactive concentrations which exceed 10 times the derived air concentration.

(3) Surface contamination levels which exceed 100 times the Department of Energy surface contamination guideline.

5) Law Risk Confined Space Entry - Entry into a confined space which is found to have acceptable safety and health conditions (i.e., the atmosphere is not considered toxic, flammable, oxygen deficient, oxygen enriched, and there are no other unacceptable safety or health hazards); and there must be an extremely low probability of occurrence for a potential hazard, especially one that could be life threatening. Activities that are to be conducted in the space shall be reviewed to determine their impact on the classification of the space.

6) Qualified Person - A person who by reason of training, education, medical suitability (as required), and experience is knowledgeable in the specific work to be performed and is competent to judge the risks associated with confined space entry.

7) Retrieval Line - A line or rope secured at one end to the worker's safety belt, chest or body harness, or wristlets, with the other end secured to either a lifting device or to an anchor point located outside the confined space entry portal.

E. Attachments

1) Attachment 1 - Confined Space Entry/Work Permit.

2) Attachment 2 - Confined Space Entry Log.

1.02 RELATED WORK

1) Section 01180, Respiratory Protection.

2) Section 01190, Lockout/Tagout. 


\subsection{REFERENCES}

A. American Conference of Governmental Industrial Hygienists - TLVs for Chemical Substances in the Work Environment Adopted by American Congress of Governmental Industrial Hygienists with current edition.

B. ANSI 2117.1 - 1989, Safety Requirements for Confined Spaces.

C. OSHA Construction Industry Standards, 29 CFR 1926.

\subsection{SUBMITTALS}

The following submittal information shall be provided to the construction Manager before the Contractor performs confined space entry/work:

A. Emergency $P l a n$. A plan for supplying emergency response/rescue and medical services.

B. Qualified Person List. List of employees needing access to a confined space. Provide the employee's full name, social security number, job duties (pertaining to confined spaces), and training information including the title of course(s), training date, and training organization.

C. Permits. Confined Space Entry/Work Permit(s). (Entry/Work is not permitted until an approved permit is returned.)

D. Submittal Updates. Update submittals to indicate current status.

E. Training Certificates. Provide a copy of a certificate or a letter of completing the required training for all personnel supervising, planning, entering, or participating in confined space entry.

F. Training Plan. A training program meeting the requirements stated in Part 3 of this section.

G. Medical Suitability. A letter specifying medical suitability is required for each Contractor's confined space entrant.

\section{PART 2 - PRODUCTS}

2.01 EQUIPMENT

A. Lighting

1) Use explosion-proof lighting when the potential of flammable vapors or combustible dusts exists. This includes low-voltage lighting.

2) Provide a ground-fault circuit interrupter for al1 $110-V$ cord-connected lighting. 


\section{A-31}

B. Tools

1) Power tools shall be either pneumatic or electric.

2) Electrical power hand tools shall be protected by a ground-fault circuit interrupter.

3) All tools (power or manual) used when the potential of flammable vapors or combustible dusts exists shall be sparkproof.

C. Compressed Gas/Flammable Equipment

Do not place cylinders of compressed gases, except for self-contained breathing apparatus or resuscitation equipment, in a confined space.

D. Ventilation

All ventilation equipment shall be approved for the class hazard of the confined space. Class I, Div. I, if flammable vapors are present or potentially exist and Class II, Div. I, if combustible dusts are present.

E. Signs

All signs required for a confined space shall be legible from $20 \mathrm{ft}$.

PART 3 - EXECUTION

3.01 INSPECTION

A. Initial Evaluation

The Construction Manager will perform the following:

1) Initial testing of the confined space. As a minimum, testing includes evaluation of oxygen, flammability, and toxic substances, as appropriate (radiation as applicable). Testing results will be recorded on the permit.

2) After the atmosphere testing and area evaluation, the area will be verified as either "Low Risk" or "High Risk" and the boundary limits establi shed.

3) Atmospheric testing of all confined spaces is required before entry unless the Construction Manager makes an exception to this requirement. This exception will be placed on the confined space work/entry permit, Part 2, under "special conditions." 
4) Determine if mechanical ventilation is required to improve the confined space atmosphere. Tests will be performed with ventilation on and off. Confined spaces will not be reclassified from "High Risk" to "Low Risk" because of the use of ventilation equipment.

5) If work introduces new hazards, stop work in the confined space area. Reevaluate the area and implement appropriate control measures to ensure worker safety before resuming work.

B. Reevaluation

The Construction Manager, or Contractor's personnel approved by the Construction Manager, shall perform the following:

1) Vacancies for "High Risk" areas greater than $30 \mathrm{~min}$, require the atmosphere to be retested and the area reevaluated before reentry is permitted. Record monitoring results on the Confined Space Entry/Work Permit.

2) For all confined spaces where work is cont inuous, the atmosphere and area shall be retested and reevaluated for each shift. Record monitoring results on the Confined Space Entry/Work Permit.

3) The duration requirement for retesting and reevaluating "Low Risk" areas due to vacancy will be designated on the entry permit by the Construction Manager. When atmosphere testing is required, under no circumstances (continuously occupied or vacated) shall atmosphere retesting be longer than an 8-h period.

\subsection{PREPARATION}

A. Medical Evaluation

Before initial entry into a confined space, the Contractor shall provide a medical evaluation to verify the physical and psychological suitability for all entrants. The evaluation shall be performed by a physician or other licensed medical practitioner.

B. Training

1) Submit a formal training program to the Construction Manager for written approval. In addition to the training requirements in ANSI 2117.1 , the program shall include the following items:

a. A training outline.

b. Trainers names and their qualifications.

c. An explanation of the principles of isolation, lockout/tagout, and ventilation. 
d. A comprehensive written examination.

e. A letter or certificate provided to individuals, signed by the trainer, stating the individual successfully completed the training.

2) All personnel shall be trained in accordance with the approved training program before being authorized to enter a confined space area.

3) Before initially entering a confined space, personnel shall receive an entry specific briefing from a qualified person. Answer or resolve all worker questions or concerns before entry into the confined space. The briefing shall include as a minimum a review of:

a. potential hazards;

b. signs, symptoms, and consequences of exposure to the hazards;

c. proper usage of personal protective equipment and controls; and

d. actions to take in case of an emergency.

C. Emergency Response Guidelines

Submit an emergency plan that meets the requirements in ANSI 2117.1 . State if it is intended to use the FM's rescue and medical personnel.

D. Entrance Posting and Flagging

1) For all confined spaces, post a copy of the entry permit in a conspicuous place, close to the entrance. Protect the permit from adverse weather conditions.

2) For all confined spaces, post a sign at the entrance including, but not limited to, the following information:

DANGER

CONFINED SPACE

PERMIT REQUIRED FOR ENTRY

AUTHORIZED PERSONNEL ONLY

3) For all confined spaces, flag off the area with removable barriers or barrier tape to prevent the inadvertent entrance of unauthorized personnel.

E. Lockout/Tagout Verification

Before entry into a confined space, verify equipment has been locked out in accordance with Sect. 01190. 


\subsection{INSTALLATION/APPLICATION/ERECTION}

\section{A.34}

The following are requirements in addition to those stated in ANSI 2117.1 and 29 CFR 1926:

\section{A. General}

1) Review engineering transmittals or drawings for activities that can create new confined space areas or additional risks in existing confined spaces. Notify the Construction Manager of all suspect confined spaces.

2) A Confined Space Entry/Work Permit, Attachment 1, is required for every confined space. The Contractor shall initiate and submit the permit, at least 10 working days before the scheduled activity, to the Construction Manager. Unplanned or emergency confined space entry/work will be handled by the Construction Manager on a case-by-case basis.

3) Provide a Confined Space Entry/Work Permit, Attachment 1, for excavations over $4 \mathrm{ft}$ in depth. This requirement includes trenches and open excavations. The Construction Manager will determine if the trench meets the definition of a confined space. The evaluation and requirements will be placed on the permit and posted. Posting, adjacent to the excavation, is required even if it was determined not to be a confined space.

4) Work in the confined space shall not be permitted until an approved confined space entry permit is returned to the contractor and posted at the job site.

5) An attendant shall be assigned to each confined space.

6) Matches, cigarette lighters, or other ignition sources are not permitted in confined spaces which contain or potentially contain flammable vapors or combustible materials.

7) Do not place cylinders of compressed gases (except for self-contained breathing apparatus or resuscitation equipment) in the confined space.

8) Employees shall not enter a confined space until submittals demonstrate al1 requirements are met.

B. Qualified Person Duties

The following shall be done by a Contractor's qualified person or by the Construction Manager if the Contractor does not have a qualified person.

1) Provide an initial preentry briefing to personnel entering a confined space.

2) Ensure entrants utilize protective equipment properly. 


\section{A.35}

3) Perform retesting and reevaluation of the confined space area as required in para. 3.01 B.

4) Ensure atmosphere testing equipment is callbrated and maintained in accordance with the manufacturer's instructions.

C. Attendant Duties

In addition to the requirements stated in ANSI 2117.1, the Contractor's attendant shall have the following duties:

1) Does not enter the confined space at any time, especially for a rescue at tempt.

2) Verifies the required atmosphere testing has been performed before personnel entry.

3) Verifies entry permit is completed, accurate, and posted at entrance.

4) Be present at all times during confined space entry/work.

5) Be able to communicate with entrants in the confined space at all times.

6) In the event of an emergency, direct entrants to evacuate the confined space and summon rescue personnel.

7) Monitors only one confined space at a time.

8) Keeps all unauthorized personnel away from the confined space.

9) Maintains an Entry Log, Attachment 2, of 11 entrants into the confined space. Initials the time in and out for each individual on the log.

10) Orders entrants to evacuate a confined space immediately when:

a. An alarm from an air-testing or other safety-related device is activated.

b. A condition is observed that is not allowed on the entry permit.

c. Detection of behavior abnormalities from possible hazard exposure.

d. The attendant has to leave the work station and no substitute attendant is available.

e. Additional hazards are suspected. 
D. High Risk Entry Requirements

$$
\text { A. } 31
$$

The following are additional requirements for "High Risk" confined space entries:

1) Vacancles greater than $30 \mathrm{~min}$ require the atmosphere to be retested and the area reevaluated.

2) Retrieval equipment shall be avallable on-site and operational before entry.

3) All entrants shall wear a safety harness and retrieval line, unless the use of equipment increases the overall risk to the entrant.

4) Engineering controls are to be used to reduce the hazards present. If engineering controls do not reduce the hazards to acceptable levels, then personal protect tve equipment is to be used in accordance with applicable standards and regulations. Respirators, If required, shall be used in accordance with Sect. 01180, Respiratory Protection.

E. Entry Pormit

The following pertains to the Confined Space Entry/Work Permit:

1) A permit is needed for each potential confined space entry/work.

2) The Contractor shall complete part 1 of the permit and the construction Manager will complete Part 2.

3) List the safety or health concerns identifled.

4) Post at confined space entrance and excavations greater than $4 \mathrm{ft}$ in depth.

END OF SECTION 
SECTION 01170

CARCINOGEN CONTROL

PART 1 - GENERAL

1.01 DESCRIPTION

A. This section provides the construction requirements for controlling carcinogentc materials on a project. Using or working with carcinogenic materials shall be in accordance with 29 CFR 10/0, Subpart 2 and additional requirements stated in this section. The Contractor is responstble for determining the most recent carcinogentc control requirements established by federal, state, and local government regulations. If conflicts exist between applicable requirements and this section, the most stringent provisions apply.

B. Carcinogen Identification

1) The following carcinogenic or suspected carcinogenic material is expected to be encountered while working at the existing factiftites: polychlorinated biphenyls.

2) If existing carcinogenic or suspect carcinogenic material, not previously identified, is encountered during renovations or demolition activities. Immodiately notify the Construction Manager. Within $10 \mathrm{~d}$, the Contractor will be given further instructions.

3) The Contractor is responstble for proper identification of carcinogen substances brought on-site. The substances shall be on an approved plan (Attachment 1) before delivery to the job site.

4) This procedure does not npoly to the handing of samples of unknown composition for analysis in the work place nor does it apply to the nonoccupational use of products such as cosmetics, prescription drugs. and tobacco.

C. Defintitions

The following definitions are in addition to those provided in Occupational Safety and Health Act (OSHA) 29 CFR 1910:

1) Carcinogen: A material or substance that, based on evaluated evidence, may cause cancer in man. Chemicals are considered as carcinogens if the carcinogen is present in concentrations of $0.1 \%$ or greater by volume. Attachment 3 is a list of known or possible human carcinogens. 


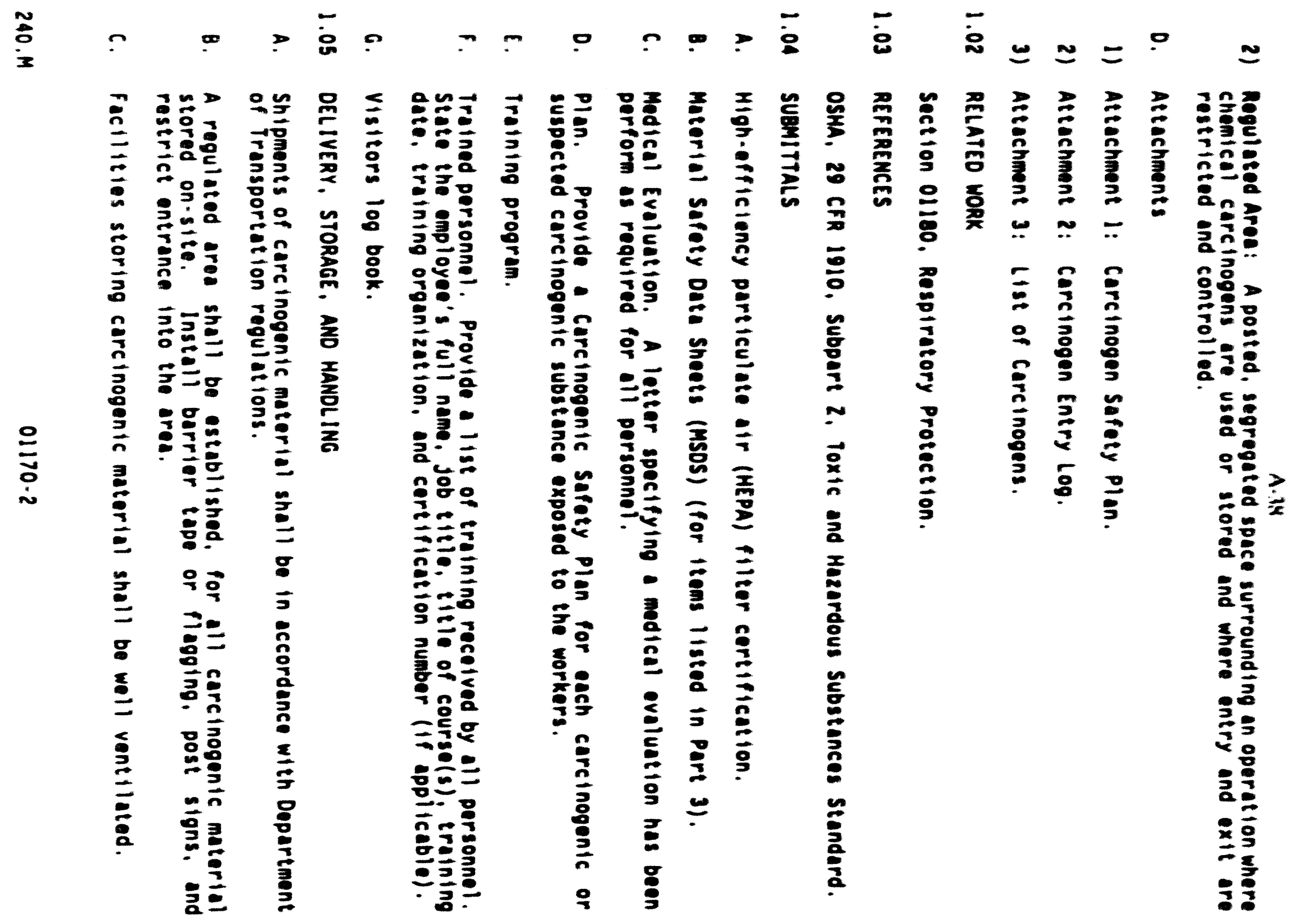




\section{A.19}

D. Identify all storage containers with weather-resistant labels. The labels shall name the carcinogentc substance and have the warning "CANCER - SUSPECT AGENT."

E. Place carcinogenic storage containers into a separate unbreakable container before transporting the material on-site.

F. Maintain a current inventory of all Contractor-owned carcinogens or suspect carcinogens on-site. The inventory shall include the quantity and location of the carcinogen substance. The inventory information shall be located on-site and evallable upon request.

\section{PART 2 - PROOUCTS}

\subsection{MATERIALS}

1) Use chemical carcinogens in only those situations where no other practical substitutes are avallable.

2) Notify the Construction Manager if a noncarcinogente matertal cannot be substituted for a carcinogenic substance.

3) HEPA fllters shall provide an effictency of not less than $99.97 \%$ when challenged with 0.3 micrometer particle-size cerosol. Provide a certification of all HEPA fllters used on-site.

\subsection{EQUIPNENT}

A. All vacuum cleaners shall be equipped with a HEPA fllter.

B. All signs shall be in accordance to 29 CFR 1910, Subpart 2 and legiblo from 20 it away.

\section{PART 3 : EXECUTION}

\subsection{PREPARATION}

A. Material Identification

1) Refer to the MSDS or other manufacturer information for all matertal brought on-site to determine if arcinogenic substance is present. Attachment 3 is a list of carcinogens that shall be considered.

2) If the presence of a carcinogenic material cannot be determined, the Contractor shall notify the Construction Manager. The Construction Manager may arrange for sample test of the material.

3) Submit an MSDS for the following ltems: Paints, solvents, adhesives, epoxy materials, etc. 
B. Plan Requirements

1) A Carcinogenic Safety Plan, Attachment 1, is required for the handling or storage of each carcinogen substance on-s1te. The Contractor shall complete part 1 and submit the plan to the Construction Manager at least $10 \mathrm{~d}$ before the scheduled activity.

2) The Contractor shall have complete approved plan before handing carcinogentc material.

C. Medical Evaluation

Before handing or working with carcinogentc matertal, the Contractor shall provide a medical evaluation of all workers possibly exposed to carcinogenic material. The evaluation shall be from alicensed physician.

D. Training

1) Submit a training program to the Construction Manager for approval. In addition to the training requirements in OSHA 29 CFR 1910, the training program shall include the following items:

a. nature of the hazard, including local and system toxictiy;

b. control messures in place;

c. medical survelllance requirements;

d. environmental monitoring and decontamination techniques;

e. emergency procedures, Including the employee's role; and

f. the location and avallablitty of the MSOS.

2) Before handling or working with carcinogentc or suspected carcinogentc material, all workers shall be trained in accordance to the approved training program.

3) After the initial training, employees shall recelve training on an annual basis.

3.02 INSTALLATION/APPLICATION/ERECTION

A. Establish Regulated Area

1) Immediately, establish regulated area by installing barrier tape or flagging. Post sign(s) in accordance with 29 CFR 1910 at all possible entrances into the regulated area. 
A.41

2) As a minimum, all carcinogenic signs shall have the following information:

\section{CANCER-SUSPECT AGENT}

AUTHORIZED PERSONNEL ONLY

B. Visitors Log Book

1) Maintain a written $\log$ book of all visitors, other than personnel identified on the plan, entering a regulated area.

2) Use the log form, Attachment 2, for log book information.

3) Submit the $\log$ book at the end of the project.

C. General Requirements

1) Immediately notify the Construction Manager of spills involving carcinogenic materials.

2) The MSDS of carcinogenic materials shall be avallable to all personnel upon request.

3) Eating, drinking, smoking, chewing gum or tobacco, applying cosmetics, taking medication, and storing food is not permitted in regulated areas.

4) Hand-washing and shower facllities shall be made avallable to the workers after handing carcinogenic materlal. These facllities shall be provided by the Contractor.

5) A Contractor-furnished emergency eye wash shall be located near each controlled work area.

6) If Contractor-provided mechanical ventilation is required (as stated in Part 2 of the plan), it shall be in place and operational before the carcinogentc substance is handled. If possible, supply air shall come from outside the regulated area. Discharge exhaust air to the outdoors clear of occupied buildings and air intakes.

7) To reduce the possibility of atrborne carcinogenic material, occasionally wet mop or vacuum the regulated area. The use of dry sweeping, dry mopping or compressed air for cleaning is prohibited.

8) Quantities of chemical carcinogens present in the regulated work area shall not exceed the amount required for use in one day. Working quantities of carcinogens shall be in containers that identify the substance and have the warning "CANCER-SUSPECT AGENT." 
9) Contaminated material leaving the regulated area shall be placed in a plastic bag or other suitable impermeable sealed primary container. The primary container shall be placed in a durable outer container before being transported. The outer container shall identify the carcinogenic substance and have the warning "CANCER-SUSPECT AGENT."

D. Disposal Requirements

1) A completed disposal form is required at least $10 \mathrm{~d}$ before scheduled disposal of carcinogen waste. Forms are avallable from the construction Manager.

2) An appropriate MSDS shall be attached to the disposal form.

3.03 FIELD QUALITY CONTROL

Monitor the regulated area for airborne exposure levels in accordance to Part 2 of the plan. Submit all monitoring results at the end of the activity or upon request.

3.04 PROTECTION

1) Required protective clothing, as stated on Part 2 of the plan, shall be worn by all personnel in the regulated areas when carcinogens are being handled.

2) Where chemical carcinogens are used or stored, cover all work surfaces with stainless steel, plastic trays, dry absorbent plastic backed paper, or other impervious material.

3) Respirator requirements will be identified in Part 2 of the plan. Respiratory protection shall be in accordance with Sect. 01180.

END OF SECTION 


\section{ATTACHMENT 1 \\ CONSTRUCTION \\ CARCINOGEN SAFETY PLAN}

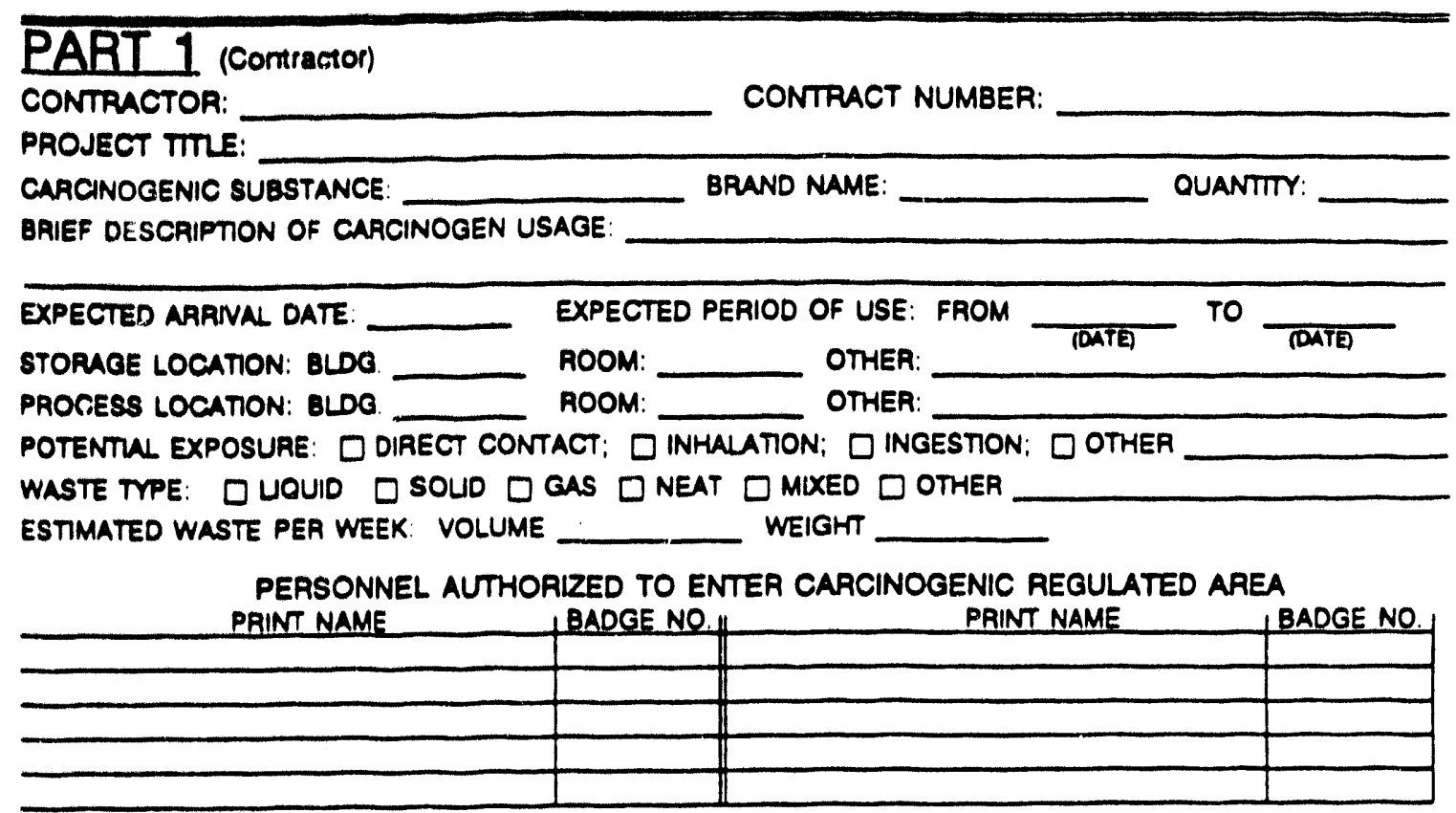

MATERIN SAFETY DATA SHEET ATTACHED $\square$ YES $\square$ NO

SIGNATURE

DATE

PART 2 (Construction Manager)

PERSONAL PROTECTIVE EQUIPMENT REQUIRED

Head Cover; $\square$ Tyvek Suit; $\square$ Lab. Coat; $\square$ Coveralls; $\square$ Gloves - Specity type

$\square$ Eye Protection; $\square$ No Respirator; $\square$ Full-Face Respirator; $\square$ Hall-Face Respirator; Canister/Cantridge Type Maximum hours of usage

Other(s)

ENGINEER CONTROLS REQUIRED

$\square$ Laboratory Hood; $\square$ Acid Hood; $\square$ Walk-in Hood; $\square$ Glove Box Only; $\square$ Scrubber;

$\square$ Local Exhaust Fan.CFM _. $\square$ Charcoal Fiter, $\square$ HEPA Finer; $\square$ Vacuum; $\square$ Other

MONTTORING REQUIREMENTS

Medical Sunvillance. Specity

Personnel Monitoring. Specity

Atmosphere Monitoring. Specity

EXIT REQUIREMENTS

Removal of Personal Protective Equipment; $\square$ Decomaminate Personal; $\square$ Decontaminate Equipment Other/Comment

COMMENTS

APPAOVAL SIGNATURE

DATE

$\square$ COPY OF COMPLETED PLAN SENT TO FACILTIES MANAGER. DATE
231.2
01170-7 


\section{CARCINOGEN ENTRY LOG}

CONTRACTOR

CONTRACT NUMBER

PROJECT TILE

CARCINOGEN MATERIAL

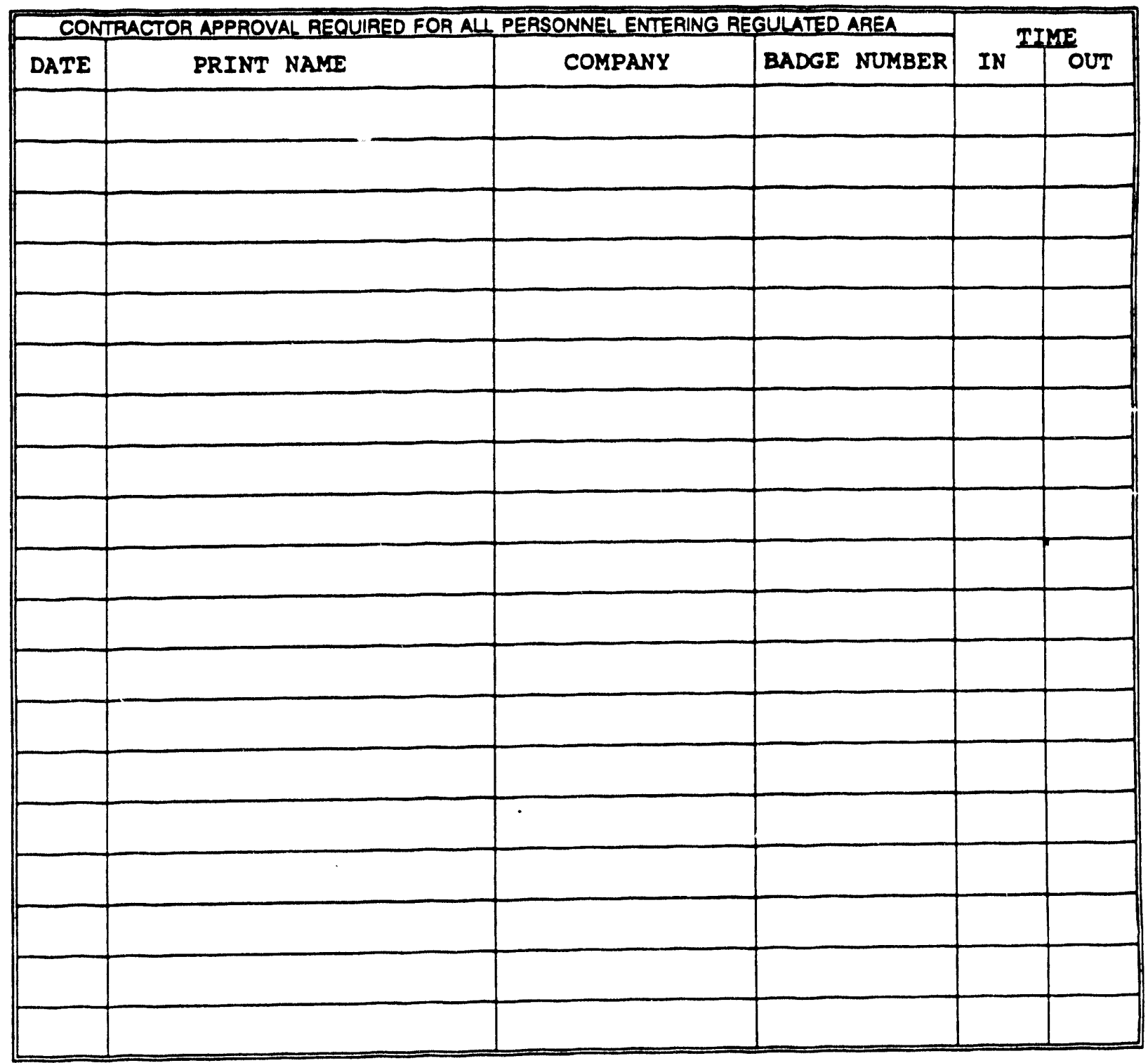




\section{ATTACHMENT 3}

\section{KNOWN OR SUSPECTED CARCINOGENS}

2-Acetylaminofluorene

Acrylamide - skin

Acrylonitrile - skin

Adriamycin

Aflatoxins

4-Aminodiphenyl - skin

Amitrole

Androgenic (Anabolic) Steroids

Antimony Trioxide Production

Arsenic and Arsenic Compounds

Arsenic Trioxide Production

Asbestos

Auramine, Technical Grade

Azathioprine

Benz(a)Anthracene

Benzene

Benzidine - skin

Benzidine-based Dyes

Benzidine Dihydrochloride

Benzo(a)pyrene

Beryllium and Compounds

Betel Quid with Tobaccco

Bis(chroromethyl)ether

Bischloroethyl Nitrosourea

Bis(2-chloroethyl)-2-napthulamine; N,N

1,3-Butadiene

1,4-Bitanediol Dimethylsulfonate

Cadmium and Compounds

Carbon Tetrachloride - skin

Chlorambucil

1-(2)Chloroethyl)-3-Cyclohexyl-1-Nitrosourea

1-(2-Chloroethy 1)-3-(4-Methulcyclohexy)-1-Nitrosourea

Chloroform

Chloromethyl Methyl Ether

Chlorotrianisene

4-Chloro-1,2-Benzendiamine

Chromite Ore Processing
Chromium (VI), water

insoluble compounds as listed:

Zinc chromate

Calcium chromate

Lead chromate

Barium chromate

Strontium chromate

Sintered chromium trioxide

Chrysene

Cisplatin

Coal Tar Pitch Volatiles as benzene solubles

Coke Oven Emissions

Creosote

P-Cresidine

C.I. Direct Black 38; Disodium Salt

C.I. Direct Blue 6; Tetrasodium Salt

2,4-Diaminoanisole Sulfate

Cyclophosphamide

Dibenz(a,h)Anthracene

1,2-Dibromo-3-Chloropropane

3,3'-Dichlorobenzidine - skin

Diethylstilbestrol

Diethyl Sulfate

4-Dimethylaminoazobenzene

Dimethyl Carbamoyl Chloride

1,1-Dimethylhydrazine - skin

Dimethyl Sulfate - skin

Epichlorohydrin

Erionite

Estrogens

Nonsteroidal

Steroidal

Estrogen-Progestin Combinations

Sequential Oral Contraceptives

Combined oral contraceptives

Ethylene Dibromide - skin

Ethylene Oxide

Ethyleneimine

N-Ethyl-N-Nitrosourea

Formaldehyde

Hematite Underground Mining 
ATTACHMENT 3 (Continued)

\section{KNOWN OR SUSPECTED CARCINOGENS}

Hexachlorobutadiene

Hezamethyl Phosphoramide - skin

Hydrazine - skin

Isopropyl Alcohol Manufacturer

Lead Chromate

Melphalan

Methoxsalen with UV-A Therapy

5-Methoxypsoralen

Methylene Chloride

4,4'-Methylene Bis(2-Chloroaniline) - skin

4,4'-Methylene Dianiline

Mehtylhydrazine - skin

Methyl lodide - skin

N-Mehtyl-N'-Nitro-N-Nitrosoquanidine

$\mathrm{N}$-Methyl-N-Nitrosourea

Mirex

Mineral Oils, Impure

MOPP (Combined Chemotherapy)

Mustard Gas

Nafenopen

B-Naphtyhlamine

a-Naphylamine

Nickel and Nickel Compounds

Nickel Refining

4-Nitrodiphenyl

Nitrogen Mustard

2-Nitropropane

Nitrosoimino Diethonol

Diethonol Nitrosamine

$\mathrm{N}$-Nitrosodiethylamine - skin

$\mathrm{N}$-Nitrosodimethylamine

Oestradiol Dipropionate

Oestradiol 3-Benzoate

Oxyretholone

Phenacetin

$\mathrm{N}$-Phenyl-beta-haphthylamine

Phenoxyacetic Acid Herbicides

Phenylhydrazine - skin

Phenytoin

Phenytoin Sodium Salt

Polychlorinated Biphenyis

Polyoestrodiol Phosphate
Procarbazine

Procarbazine Hydrochloride

Propane Sultone - skin

Beta-Propiolactone

Propyleneimine - skin

Propylene Oxide

Radon

Refractory Ceramic Fibers

Silica, Crystalline

Silicon Carbide Whisker Fibers

Soots

Streptozotocin

Styrene Oxide

Talc Containing Asbestiform Fibers

Tars

Testosterone

4,4-Thiodianiline

Therium Dioxide

Tobacco Products, Smokeless (not applicable)

Tobacco Smoke

O-Tolidine - skin

o-Toluidine - skin

p-Toluidine - skin

Toxaphene

Trecsulphan

Tris(1-Aziridinyl)Phosphine Sulfide

Tris(2,3-Dibromopropyl)phosphate

Vinyl Bromide

Vinyl Chloride

Vinyl Cyclohexene Dioxide - skin

Xylidine (mixed isomers) - skin

Zinc Chromate

\section{NOTE}

Listed substances followed by the designation "skin" refer to the potential contribution to the overall exposure by the cutaneous routes including mucous membranes and eyes either by airborne or, more particularly, by direct contact with the substance. Vehicles can alter skin absorption. 
ATTACHMENT 3 (Continued)

KNOWN ANIMAL CARCINOGENS

Acetamide

Acetomethoxan

2-Acetylaminofluorene*

Actinomycin D

AF-2

2-Aminoanthraquinone

2-Amino-4-Nitroanisole

2-Amino-5-[5-Nitro-2-Furyl]-1,3,4-Thiadiazole

Amitrole*

O-Hydrochloride Anisidine

O-Anisidine

Aramite

Aurothioglucose

Azaserine

Aziridinyl Benzoquinone

2-[1-Aziridinyl]Ethanol

Azobenzene

Benzene Hexachloride

Benzotrichloride

Benzo (A) Pyrene*

Benzo (B) Fluoranthene

Benzo (J) Fluoranthene

Benzo (K) Fluoranthene

Benzyl Violet 4B

Benz (A) Anthracene

Benz (C) Acridine

Bis(Chloroethyl) Nitrosourea*

1,4-Bis(Chloromethoxymethyl) Benzene

Bis(1-Aziridinyl)Morpholinophosphene Sulfide

Bis (2-Chloroethyl) Ether

Bis (2-Hydroxyethyl) Dithiomonopotassium

Salt of Carbamic Acid

Blue VRS

Brilliant Blue FCF

Disodium Salt Beta, Butyrolactone

Cantharidin

Carbamylhydrazine Hydrochloride

Carbon Tetrachloride*

Carrageenan

Chloramphenicol

1-(2-Chloroethyl)-3-Cyclohexyl-1-Nitrosourea
Chloroform *

Chlorophenols

Chrysene*

Chrysoldine

Citrus Red No. 2

Coumarin

Creosote*

Cryogenenine

Cupterron

Cycasin

Cyclochlorotine

C.I. Disperse Orange

C.I. Solvent Orange 2

C.I. Solvent Yellow 1

C.l. Solvent Yellow 3

Dacarbazine

Daunomycin

Diacetylbenzidine

4,4'-Diaminodiphenyl Ether

Diazomethane

Dibenzo(A,E)Pyrene

Dibenzo(A,H)Pyrene

Dibenzo(A,I)Pyrene

Dibenzo(A,L)Pyrene

7H-Dibenzo(C,G)Carbazole

Dibenz $(A, H)$ Acridine

Dibenz(A,H)Anthracene

Dibenz(A,J)Acridine

3,3'-Dichlorobenzidine *

Dichlorodiphenyltrichloroethane

2,4-Dichlorophenyl P-Nitrophenyl Ether

1,1-Dichloro-2,2-Bis(P-Chlorophenyl)Ethane

1,1-Dichloro-2,2-Bis(P-Chlorophenyl)Ethylene

3,3'-Dichloro-4-4'-Diaminodiphenyl Ether

Dienoestrol

Diepoxybutane

1,2-Diethylhydrazine

Diethylstilbestrol Dipropionate

Dihydrosafrole

3,3-Dimethoxybenzidine

P-Dimethylaminoazobenzene *

$231 . \mathrm{L}$

01170-11 
ATTACHMENT 3 (Continued)

KNOWN ANIMAL CARCINOGENS

Trans-2-[Dimethylamino) Methylamino]-5-2-

(5-Nitro-2-(Furyl)(Vinyl)]-1,3,4-Oxadia Zole

Dimethylcarbamyl Chloride

1,2-Dimethylhydrazine

1,1-Dimethylhydrazine*

1,4-Dioxane

1,2-Diphenylhydrazine

Direct Black 38 [Technical Grade]

Direct Blue 6 [Technical Grade]

Direct Brown 95 [Technical Grade]

DI-(2-Ethylhexyl)Phthalate

3,4-Epoxy-6-Methylcyclohexylmethyl-3,4-Epoxy-

6-Methyl Cyclohexane Carboxylate

Estradiol Mustard

Estradiol-17B

Estrone

Ethinyloestradiol

Ethyl Methanesulfonate

Ethylene Dibromide*

Ethylene Dichloride

Ethylene Glycol Bis(Chloromethyl) Ether

Ethylene Oxide*

Ethylene Sulphide

Ethyleneimine*

Ethylenethiourea

Evans Blue

Fast Green FCF

Formaldehyde*

2-[2-Formylhydrazino]-4-[5-Nitro-2-Furyl]

Thiazole

Glycidaldehyde

Griseofulvin

Guinea Green B

Gyromitrin

Hexachlorobenzene

Hexamethyl Phosphoramide*

Hydrazine

Hydrazine Hydrogen Sulfate

Indeno(1,2,3-CD)Pyrene

Iron Dextran

Isatidine
Isonicontinic Acid Hydrazide

Isosafrole

Kepone

Lasiocarpine

Lead Acetate

Lead Phosphate

Mannomustard Dihydrochloride

Mechloroethamine Hydrochloride

Mestranol

Methyl lodide*

Methyl Methanesulfonate

Methylazoxymethanol

Methylazoxymethanol Acetate

5-Methylchrysene

4,4'-Methylene Bis(2-Methylaniline)

4,4'-Methylene Bis(2-Chloroaniline)*

Methylenedianiline

2-Methyl-1-Nitroantraquionone

Metronidazole

Michler's Base

Michler's Ketone

Mitomycin C

Monocrotaline

Monuron

5-(Morpholinomethyl)-3-[(5-Nitrofurfurylidene)

Amino]-2-Oxazolidinone

M-Toluenediamine

Niridazole

Nitrilotriacetic Acid

4-Nitrodiphenyl*

1-[(5-Nitrofurfurylidene)Amino]-2-Imidazolidene Nitrogen Mustard N-Oxide

Nitrogen Mustard N-Oxide Hydrochloride

2-Nitropropane *

5-Nitro-Acenaphthene

$\mathrm{N}$-[4-(5-Nitro-2-Furyl)-2-Thiazolyl]Acetamide

Noresthisterone

N-Methyl-N'-Nitro-N-Nitrosoguanidine

$\mathrm{N}$-Nitrosodiethanolamine

N-Nitrosodiethylamine

$\mathrm{N}$-Nitrosodimethylamine*

$\mathrm{N}$-Nitrosodi-N-Butylamine 
ATTACHMENT 3 (Continued)

KNOWN ANIMAL CARCINOGENS

N-Nitrosodi-N-Propylamine

N-Nitrosomethylethylamine

$\mathrm{N}$-Nitrosomethylvinylamine

N-Nitrosomorpholine

N-Nitrosonornicotine

N-Nitrosopiperidine

N-Nitrosophyrrolidine

N-Nitrososarcosine

$\mathrm{N}$-Nitroso-N-Ethylurea

N-Nitroso-N-Methylurea

$\mathrm{N}$-Nitroso-N-Methylurethane

Oestradiol-17-Beta-Valerate

Oestriol

Oestrone Benzoate

Oxazepam

Oxymetholone *

O-Toluidine Hydrochloride

Phenazopyridine

Phenazopyridine Hydrochloride

Phenobarbital Sodium

Phenoxybenzamine Hydrochloride

Polybrominated Biphenyls

Ponceau MX

Ponceau 3R

Progesterone

Pronetalol Hydrochloride

Propane Sultone*

B-Propiolactone*

N-Propyl Carbamate

Propylene Imine*

Propylene Oxide

Propylthiouracil

P-Nitrosodiphenylamine

Resperpine

Retrorsine

Rhodamine B

Rhodamine 6G

Saccharin

Satrole

Selentium Sulfide
Sequential Oral Contraceptives

Shale Oil

Sterigmatocystin

Streptozotocin*

Sudan 1

Sudan II

Sulfallate

Tannic Acid

Terpene Polychlorinate

2,3,7,8-Tetrachlorodibenzo-P-Dioxin (TCDD)

$1,1,2,2-$ Tetrachloroethane

Thioacetamide

2-Thiouracil

Thiourea

O-Tolidine*

O-Toluidine*

Triethylene Glycol Diglycidyl Ether

1,2,3-Tris(Chloromethoxy) Propane

2,4,6-Tris(1-Aziridinyl)-S-Triazine

TRP.P.1

TRP.P-2

Trypan Blue (Commercial Grade)

Uracil Mustard

Urethane

Vinylcyclohexene Dioxide*

*Also designated as human suspect carcinogen by another organization. 
PART 1 - GENERAL

\subsection{DESCRIPTION}

A. This section provides the respiratory protection requirements for all construction personnel. Work shall be performed in accordance with Standard 29 CFR 1910.134 and requirements stated herein.

The use of respirators is required for the following work:

1) Confined Space Entry and Work

2) Carcinogen Control

3) During HAZWOPER work removing liquids and sediments from tanks.

B. Definitions

Single-use of respirator: The time period starting at entry into the hazardous work area until the respirator face-to-face piece seal is broken. Essentially one donning and doffing cycle.

\subsection{REFERENCES}

A. American National Standards Institute (ANSI) 288.2, "Practices for Respiratory Protection."

B. ANSI 288.6, "For Respiratory Protection - Respirator Use - Physical Qualifications for Personnel."

c. Occupational Safety and Health Act (OSHA) Regulations for General Industry, Standard 29 CFR 1910.134, Respiratory Protection.

D. ANSI 29.2, Design and Operation of Local Exhaust Systems. Compressed Gas Association Specification, G7.1, 1966. 


\subsection{SUBMITTALS}

A. Physician's written approval.

B. List of trained personnel.

c. List of personnel recelving fit test.

D. Qualifications of personnel performing the fit testing.

E. Total number of personnel needing respirators.

F. Compressed breathing air quality data.

1.04 DELIVERY, STORAGE, AND HANDLING

Temporary storage of respirators for reuse shall be in accordance with 29 CFR 1910.134 (b) (6) and $(f)(5)$.

PART 2 - PRODUCTS

\subsection{MATERIAL}

A. Respirators with cartridges will be provided to the Contractor by the FM, except for Construction Manager procured SCBAs.

B. The Contractor shall provide breathing air, if required. Submit data demonstrating the breathing air supplied to the air respiratory protection systems meets the Compressed Gas Association Specification G7.1 requirements for Grade D breathing air.

\section{PART 3 - EXECUTION}

\subsection{INSPECTION}

The respirator shall be inspected by the wearer before its use to ensure it is properly working. Respirators stored for emergency or rescue use shall be inspected by the Contractor at least once a month.

\subsection{PREPARATION}

A. Medical Evaluation

Before an employee is issued a respirator, a physician's written approval shall be submitted. This approval shall verify the employee is able to wear a respirator in accordance with the requirements of ANSI 288.2 and ANSI 288.6. The physician's approval shall be updated annually. 
B. Training

Before an employee is lssued a respirator, the employee shall complete the general training listed in Attachment 1. Submit a ist of all trained personnel. The training shall be updated annually.

C. Fit Test

Before an employee is issued a respirator, the employee shall ieceive a quantitative fit test in accordance with ANSI 288.2. Fit factors shall be aninimum of 10 times the assigned protection factors in Attachment 2. Submit records of all personnel recelving fit test and the qualifications of personnel performing the fit test. Fit testing shall be done for initial fitting and annually afterwards except for instances where particular substance requires more frequent fit testing (Example: 29 CFR 1910.1001(g)411).

\subsection{INSTALLATION/APPLICATION/ERECTION}

A. Respirator Information

1) Respirators and cartridges are supplied by the Facilities Manager. The Contractor shall receive the required respirators from the Construction Manager. After its intended use, each respirator shall be returned to the Construction Manager. The Contractor shall be charged for shortages.

2) The Contractor shall provide the number of employees needing respirators to the Construction Manager at least $10 \mathrm{~d}$ in advance of the needed date.

3) All respirators are Mine Safety Appliance (MSA). Survivair type respirators shall be an alternate if the MSA respirator does not provide a satisfactory fit test. Both types are NIOSH/MSHA approved. The cartridge type provided is indicated in the Remedial Action Work Plan and will vary depending upon ambient air concentration readings.

4) Reuse of respirators is approved for this project provided the following is performed:

a. Cleaned respirators are placed in a clean plastic bag and stored in a secure location accessible only to the wearer.

b. Respirator cleaning materials and instructions for properly using the cleaning materials are provided to the wearer when the respirator is initialiy issued.

c. The respirator is not reused for more than 30 calendar days.

5) The Contractor shall provide optical corrections in accordance with OSHA requirements. 


\section{A. 54}

6) Quarter-mask resptrators and disposable dust masks that cannot be respirator fit tested are not permitted.

B. Face-plece seal

1) All personnel wearing a respirator shall check the respirator seal with - positive or negative pressure check before entering a harmful or potentially harmful atmosphere.

2) A respirator that requires a tight face fit shall not be used if factal hatr, head coverings, factal injurtes, scars, bandages, corrective spectacles, goggles, face shield, or welding helmet affect the face plece to face seal.

C. General Requirements

1) For each project, train all personnel on job-specific resplrator requirements as listed in At tachment 1.

2) Modifications to the respirator or its parts shall not be permitted.

3) The Contractor's supervisor shall monitor the use of respirators to ensure they are properly worn.

3.04 FIELD QUALITY CONTROL

The Construction Manager may perform periodic survetllance of the contractor's respirator program to ensure complance with this section.

3.05 PROTECTION

Whenever possible, controls shall be used to prevent atmospherle contamination of harmful lements such as dust, fumes, sprays, mists, fogs, smoke, vapor, or gases. A respirator is a secondary method of worker protection and used in conjunction with engineering controls such as ventilation, enclosures, and vacuums.

END OF SECTION 


\section{A.55}

ATTACHMENT 1

TRAINING REQUIREMENTS

A. General Iraining (Updated annually)

Each respirator wearer shall be given training which includes the following:

1. Respiratory hazards if the respirator is not properly used.

2. Types of angineering and administrative controls that may be used.

3. The functions, capabilities, and limitations of the selected respirator.

4. The method used and hands-on application of donn.ng, fit testing, and checking operation of the respirator.

5. Proper wearing of the respirator.

6. Respirator maintenance and storage.

7. Recognizing and handiling emergency situations.

B. Jeb Specific Iraining (Provided for each project)

1. Explain why respirators are needed to provide protection and the reason for selecting a particular type respirator and filter cartridge.

2. The agent for which the respirator was selected.

3. Engineering controls provided and when they are being used.

4. Previous sampling results.

5. What to do in an emergency situation. 


\section{BESPIRATOR IYPE}

Half-face, oir-purtfying

Full-face, atr-purtfying

PAPR" with loose-fitting face plece

PAPR with half-face mask (6 CFM to 15 CFM)

PAPR with full-face mask (6 CFM to 15 CFM)

Air line, half-face mask, continuous flow/pressure demand

Air line, full-face mask, continuous flow/pressure demand

Air line, full-face mask, pressure demand with egress bottle

Air line with loose fitting hood cont inuous flow

Self-contained breathing apparatus, pressure demand
APE*

20

50

25

50

100

50

1,000

IOLH $>1,000$

25

IDLH \& >1,000

-APF - Assigned Protection Factir. Quantitative fit test requires minimum of 10 times the APF. The fit test factor shall be increased if required by Occupational Safety and Health lict for a particular substance (e.g., 29 CFR 1910.101. Appendix C, requires a fit factor of 1000 for full face).

"PAPR - Powered air-purifying respirator.

$240 . M$

$01180-6$ 
SECTION 01190

LOCKOUT/TAGOUT

PART 1 - GENERAL

1.01 DESCRIPTION

A. This section provides the construction requirements for lockout/tagout of energy sources to ensure the safety of workers. Work shall be performed in accordance with Standard 29 CFR 1910.147 and additional requitrements stated herein.

This section does not apply to work on cord- and plug-connected electrical equipment when exposure to hazards of unexpected energization or startup of the equipment is controlled by unplugging the equipment and the plug is under the control of the employee performing the service or maintenance.

This section does not apply to systems greater than $600 \mathrm{~V}$.

B. Definitions

The following definftions are in addition to those provided in Standard 29 CFR 1910.147.

1) Danger Tag: A device for personnel protection that is used to inform personnel that tagged equipment is not to be operated. "DANGER - DO NOT OPERATE" tags and assoclated locking devicits shall be the only devices used to control against hazardous energy releases during servicing and/or maintenance activitios. These tags have tear-off tabs which bear the same number as the main part of the tag. These tear-off tabs are used to maintain control of isolation devices that cannot be locked by putting the tab into a lockbox and then requiring the service (Contractor) employees to lock the lockbox with personal locks. The tags may not be removed from the isolating device unt 11 the tabs are removed from the lockbox and matched to the tags. These tags shall not be used for other purposes. A "DANGER - DO NOT OPERATE" tag shall be considered the equivalent of a lock when used alone.

2) Energy Sources: All forms of energy, both latent and residual, including electrical (600 $\mathrm{V}$ and below), hydraulic, pneumatic, mechanical, chemical, radiation from radiation-generating machines, toxic, and other potentially hazardous sources. This definition expands the definition in Standard 1910.147. 


\section{A.58}

3) Lockbox: A durable container for holding keys and/or tear-off tabs to which multiple locks can be applied.

4) Lockout Device: A device that utilizes a lock and key (and other mechanical devices such as a chain, hasp, or bar secured by a lock and key) to secure an energy-isolating device in a safe position. An in-house locking device may be utilized for a molded-case circuit breaker.

5) Lockout/Tagout Log Book: A loose-leaf binder used to retain Lockout/Tagout Permits.

6) Lockout/Tagout Permit: A permit used to control and document energy isolation on all systems or equipment where documentation of the subject activity is required.

7) Temporary Suspension: A means by which lockout/tagout conditions can be temporarily suspended (removed) in order to apply energy for test or adjustment purposes.

8) Verification: Assuring that a system or equipment is at a safe energy state through checks such as attempting to operate start controls, testing or metering to measure for the presence of energy, or inspecting/observing to verify a safe energy state.

\subsection{REFERENCES}

Standard 29 CFR 1910.147, The Control of Hazardous Energy (Lockout/Tagout).

1.03 SUBMITTALS

No submittal information is required.

PART 2 - PRODUCTS

\subsection{EQUIPMENT}

A. Locks

Locks shall have the following requirements:

1) Painted or clearly marked red.

2) Identified with the Contractor's and employee's name. 


\section{B. Locking Devices}

The Facilities Manager (FM) will provide the initial locking devices, including the first lockbox. If required, additional locking devices such as chains, hasp, security bar, or lockbox(es) shall be provided by the Contractor.

PART 3 - EXECUTION

\subsection{PREPARATION}

A. Training

1) All employees working on a system needing lockout/tagout protection shall be trained (approximately $4 \mathrm{~h}$ ) before working on the system. The training will be provided by the Construction Manager. Renewal of the training is required every 2 years.

2) Maintain all personnel training reco:ds on-site and make them available upon request.

B. Advance Notification

The Contractor shall notify the Construction Manager and request the initiation of a lockout/tagout permit at least $5 \mathrm{~d}$ in advance of the date a system is needed to be out of service.

\subsection{INSTALLATION/APPLICATION/ERECTION}

A. Lockout/Tagout Process

1) The Construction Manager, after notification from the Contractor, will inform the FM of the systems needed to be out of service. The construction Manager will coordinate all lockout/tagout activities.

2) After the FM applies the required locks and danger tags, the Construction Manager will sign the lockout/tagout permit accepting the protection and then proceed to overlock the system. If overlocking is not possible, control of the FM's keys or tear-off tabs in lockbox(es) shall be used. The lockout/tagout permit shall be signed off by the FM and Construction Manager before the Contractor starts work on the system. The Contractor may request a copy of the signed permit.

3) All employees of the Contractor working on the locked out system shall have control over the removal of the protection. This may be accomplished by utilizing one of the following methods: 
A-60

a. direct overlocking of isolating devices, or

b. overlocking of lockbox(es) that contain keys from the Construction Manager's locks, or

c. overlocking of lockbox(es) that contain FM's keys or tear-off tabs of applied tags.

4) Before staring work on the system, the Contractor shall perform verification that the system is out of service.

CAUTION: Extreme caution shall be used when verifying protection. Contractor personnel shall not override "DANGER - DO NOT OPERATE" tags during the verification process. Do not attempt verification on a system without sufficient training and proper equipment. When the Contractor is verifying protection on a job already in progress, visual verification may be the only means available.

5) Upon completion of the work, the Contractor's personnel shall remove the ir locks.

6) The Contractor shall not ify the Construction Manager when work is complete and all Contractor locks are removed.

B. General Requirements

1) The FM will be the issuing authority responsible for issuing the lockout/tagout permit, maintaining the lockout/tagout $10 \mathrm{~g}$ book, and initially locking and tagging the system out of service.

2) The Contractor shall supply locks to all their personnel working on a locked out system.

3) The use of positive protection is encouraged. Positive protection includes, but is not limited to, such practices as blanking lines, double-blocking valves and venting systems, blocking fans, blocking/cribbing suspended loads, disconnecting wires, removal of fuses, and racking out breakers. The Contractor shall provide personnel needed to provide and remove the positive protection.

4) If lockbox(es) are used, a copy of the lockout/tagout permit shall be attached or immediately adjacent to the lockbox(es).

5) Violation of this procedure may warrant the Construction Manager stopping work and require retraining of all personnel at the Contractor's expense. 
C. Temporary Suspension

1) When tests, inspections, or temporary services of equipment require that the protection be suspended temporarily, the Contractor shall request a temporary suspension of protection. The Construction Manager will coordinate the review and authorize removal of all or some of the lockout/tagout protection.

2) Temporary removal of lockout/tagout protection shall be in accordance to Standard 1910.147 $f(1)$.

3) The Contractor shall remove the appropriate locks and sign the Lockout/Tagout Permit Form for Temporary Suspension.

4) The FM will sign the temporary release section of the Lockout/Tagout Permit Form.

5) The FM will remove the appropriate locks/tags and return equipment to service for testing, inspecting, or temporary service.

END OF SECTION 


\section{SECTION 01500}

CONSTRUCTION FACILITIES AND TEMPORARY CONTROLS

PART 1 - GENERAL

\subsection{TEMPORARY UTILITIES}

The Contractor shall provide the required temporary lines to use existing plant utilities. All tie-ins and disconnects to existing systems are performed by the Facilities Manager (FM). The Contractor shall submit to the Construction Manager a written request $8 \mathrm{~d}$ in advance of the needed tie-in or disconnect service. The following pertain to this project.

A. Electrical

1) Electric power, $120 \mathrm{~V}$, is available within the existing plant facility.

2) Electric power, $240 \mathrm{~V}$ and $480 \mathrm{~V}$, is available to the Contractor.

a. The Construction Manager shall perform all work including conductor runs, conductor protection (both physical and thermal), and final tie-ins in coordination with the FM. The Construction Manager shall also be responsible for returning the electrical facility equipment to its preconstruction condition.

b. Tank Southeast of Building 9201-5: The Construction Manager shall use Motor Control Center (MCC) 2NB, Compartment -4 in Building 9404-13. This circuit presently feeds a weld receptacle so the Construction Manager can either plug into it or disconnect the receptacle and tie to the load side of the switch in the MCC. This is a $480-V$, three-phase circuit breaker which is set at $50 \mathrm{~A}$. If more than $40 \mathrm{~A}(80 \%)$ is required, Compartment -13 has a 1 arger switch set at $70 \mathrm{~A}$ which can be used.

c. Tank Southwest of Building 9201-4: The Construction Manager shall use MCC 686, Compartment -4 in Building 9404-12. This circuit presently feeds a weld receptacle so the Construction Manager can either plug into it or disconnect the receptacle and tie to the load side of the switch in the MCC. This is a $480-V$, three-phase circuit breaker which is set at $50 \mathrm{~A}$. If more than $40 \mathrm{~A}(80 \%)$ is required, Compartment -6 has a larger switch set at $70 \mathrm{~A}$ which can be used.

d. Tank Southeast of Building 9201-4: The Construction Manager shall use Power Panel PP1. The Construction Manager shall provide an enclosed circuit breaker rated at the appropriate current (less than $100 \mathrm{~A})$ and install it adjacent to the panel. The Construction Manager 
A. 64

shall tap the load side of the 225 A main of Power Panel PP1 to feed the Construction Manager's breaker. The Construction Manager's breaker shall then feed the Construction Manager's load. Power Panel PPI is located on the east wall of Building 9720-46. There will be an outage required so proper planning will have to take place.

3) All temporary electrical lines shall have ground-fault interrupters.

B. Water

1) Water is available within the existing plant facility.

2) Temporary water lines shall have backflow preventers installed.

3) Water used to sterilize or flush pipelines shall be considered a hazardous waste because of the possible high concentrations of chlorine. Place into an FM storage tank to dilute the chlorine content before discharging into an existing storm or sanitary sewer, drainage ditch, or waterway.

C. Sanitation Facilities

Provide chemical toilet facilities at locations approved by the Construction Manager. Maintain the toilets in a clean, safe, and sanitary condition for the duration of the project.

1.02 DISPOSAL AREAS

All items shall be segregated when delivered to the disposal site. A 3-week delay may be required for items that are not segregated.

A. Waste

In accurdance with the Subcontract General Conditions, Article 23, deliver the following materials to the $Y-12$ Centralized Sanitary Landfill Il between the hours of $9 \mathrm{a} . \mathrm{m}$. and $2 \mathrm{p.m}$. daily. Segregate into the following categories:

See Remedial Action Work Plan (RAWP), Best Management Practices Plan, attached.

B. Waste 0 il, Solvent, and Sludge Packaging

1) See RAWP, Best Management Practices Plan, attached.

2) After filling, wipe the exterior (sides and top) of drums clean of residue and tag. Apply tag to the side of each drum. Tags shall be a UCN-2114A, "Hazardous Waste Identification," for Resource Conservation and Recovery Act hazardous wastes or a UCN-2114B, "Waste Identification," for nonhazardous waste (tags furnished by Construction Manager). Insert the tag in a self-adhesive vinyl envelope and attach to the side of the drum, near the top, and angle downward to keep out water. Mark the tag with 
permanent ink and print all information, including the Contractor's name and contract number.

3) Segregate oil, solvent, and sludge waste by type, origin, and contaminants.

4) If any packaging requirements are not met, the waste will not be accepted at the 1 andf $i 11$.

C. Hazardous Materials

See RAWP, Best Management Practices Plan, attached.

D. Salvageable Materials

See RAWP, Best Management Practices Plan, attached.

E. Recycle Waste

1) Wood: Transport to wood stroage yard.

2) Aluminum: Store on-site for Construction Manager pickup. Store cans in plastic bags.

3) Cardboard: Store on-site for Cosntruction Manager pickup. Keep neatly stacked and dry.

F. Transportation

Provide complete containment for any spoil, waste, and salvable materials during transport. See RAWP, Best Management Practices Plan, attached.

G. Disposal Permit

1) All waste and salvageable materials removed from the job site shall be accompanied by a permit. Request. for approval of a permit shall be made $24 \mathrm{~h}$ in advance of waste removal operations.

2) The approved request (permit) may be required by the FM personnel at the 1 andfill before disposing of waste.

H. Wolmanized Treated Wood

Sawdust and particles generated from the use of pressure treated wood shall be handled as hazardous waste in accordance to 40 CFR 261.24 requirements. 
PART 2 - PRODUCTS

Not used.

\section{PART 3 - EXECUTION}

Not used.

END OF SECTION 


\section{DATA SHEET}

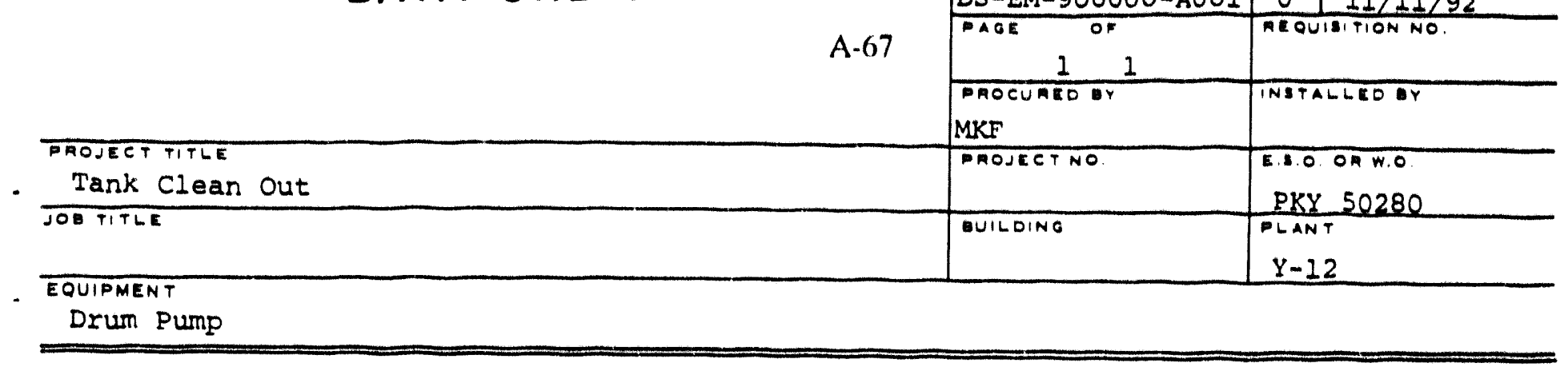

\subsection{SCOPE}

This data sheet describes an electric motor driven drum pump.

\subsection{REQUIREMENTS}

The drum pump shall include the pump, electric motor, and 1520 feet of cord, such as sethco pump model P8OH-40.

$\begin{array}{ll}\text { Size: } & \text { I" discharge } \\ \text { Length: } & 40 " \\ \text { Material: } & \text { Polypropyline } \\ \text { Capacity: } & 35 \mathrm{GPM} \\ \text { Discharge } & 10 \text { feet } \\ \text { Head: } & 115 \mathrm{~V}, \text { single phase } \\ \text { Motor: } & \end{array}$

3.0 SERVICE CONDITIONS

Media: Water

Temperature: Approx. $50-60^{\circ} \mathrm{F}$

Specific

Gravity: $\quad 1.0$

\begin{tabular}{|c|c|c|c|c|c|c|c|}
\hline \multirow{2}{*}{$\begin{array}{l}\text { Furnish the following manufacturer's } \\
\text { data in quantities indicated: }\end{array}$} & \multicolumn{3}{|c|}{ NUMBER OF COPIES } & \multirow{2}{*}{$\begin{array}{l}\text { TYPE OF DATA } \\
\text { (CONTINUED) }\end{array}$} & \multicolumn{3}{|c|}{ NUMBER OF COPIES } \\
\hline & W/Bids & Approval & Certified & & W/Bids & Approval & Celfified \\
\hline 1. Outline dimensional diawings & & & & 6. Test \& Inspection Reports & & & \\
\hline 2. Operation \& Performance data & & & & 7. Materials Certification & & & \\
\hline 3. Literature \& Parts lis! & 7 & 2 & & 8. & & & \\
\hline 4. Operating \& Maint. Instructions & & 2 & & 9. & & & \\
\hline 5. Installation instructions & & & & 10. & & & \\
\hline 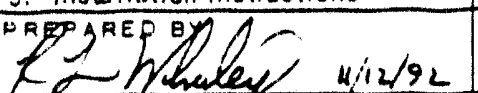 & $\mathcal{N}^{A P P R O}$ & & & PRINCIPAL ENGINEER & & 10 & दहशी \\
\hline
\end{tabular}


Appendix B

\section{AS-BUILT SPECIFICATIONS}




\section{B-3}

This appendix describes the probable sources of water to tanks $21(04 . \mathrm{U}$ and $2100 . \mathrm{U}$ and presents the as-built drawings of the tanks. During project activities, it was discovered that the sources of flow to the tanks did not represent the sources that had been assumed when the project began. Flow conditions into the various tanks were noted in the course of meeting project requirements, and tentative hypotheses about flow to these tanks were made. Known facts and hypotheses concerning flow to tanks $2104-\mathrm{U}$ and $2100 \cdot \mathrm{U}$ are presented below. Tank 2101.U was sealed off during project activities, and thus flow to that tank is no longer a concern.

Determination of flows to these tanks and remediation of sources contaminating these tanks were not part of this project. Determination of flows to these tanks may be addressed during implementation of RMPE subprojects. The ultimate sources of mercury contamination to these tanks will be remediated during the decontamination and decommissioning of buildings 9201.4 and $9201-5$.

Tank 2104-U. The sources contributing water to the tank were not precisely known prior to the beginning of removal actions. Only during project activities were the eight sump pumps located in the various fan rooms of Building 9201-5 determined not to contribute flow to Tank 2104-U. Primary sources contributing effluent to the tank included:

- three chuck vacuum pumps (J-25001 North, South, and West) near column 1-H-16 of Building 9201-5, which supplied $-98 \%$ of the tlow to the tank, and

- two process water pumps (J-301 and J-302) with wet seals near column 1-A-16 of Building 9201-5.

Possible sources of water that have not been verified include:

- three tower water pumps and a drain pipe from the second floor drain at column 1-D-18 of Building 9201-5, which may contribute flow periodically;

- floor drains in the old compressor room on the first floor of Building 9201-5; and

- other intermittent sources that have not been identified.

Tank 2100-U. At the beginning of this project, it was assumed that all eight sumps in Building 9201-4 drained to the main pipe under H-Road just northwest of Building 9404-18. When the work began, an attempt was made to determine exactly which pumps contributed flow to Tank 2100-U. All eight pumps were manually started and stopped one at a time to verif "flow through the flowmeter just north of the tank. Three men were stationed to observe flow changes at strategic points: one at the pump switch, one at the manhole just northwest of Building 9404-18, and one at the inlet to the tank. Flow through the flowmeter coincided with the start of each pump. No flow was observed at the inlet to the tank when starting and stopping one pump at a time. However, when all eight pumps started back, a flow through the inlet to the tank was observed but then stopped.

All that can be concluded without further investigation is that several of the pumps flow through the flowmeter and the others flow through an unidentified pipe to the mercury tank. One hypothesis is that there is a branch or Y-connection to the flowmeter and to the east inlet to the tank. If flow to the flowmeter is greater than the flowmeter can handle, or if the flowmeter is plugged, the flow bypasses the flowmeter and flows into the tank through the unidentified pipe. 
B.4

As-Built Drawings. Five as-built drawings are included in this appendix.

Figures 3 and 4 in the main text of this postconstruction report portray the as-built conditions of the tanks when project work was completed.

Drawings C2E900000A804, Rev. 2, and P2E900000A035, Rev, 0, which were originally part of the certified-for-construction package, are included below as Figs. B.1 and B.2.

Figure B.3 (drawing P2E119271, Rev. B) shows floor drains on the first floor of Building 9201-5. Known sources of water entering the tank on the southeast corner of the building are three chuck vacuum pumps that discharge to drain number D1023 and two process water pumps that discharge to drain number D1131. Both flows exit the building at $\mathrm{BE}-03$ and continue to the tank. 


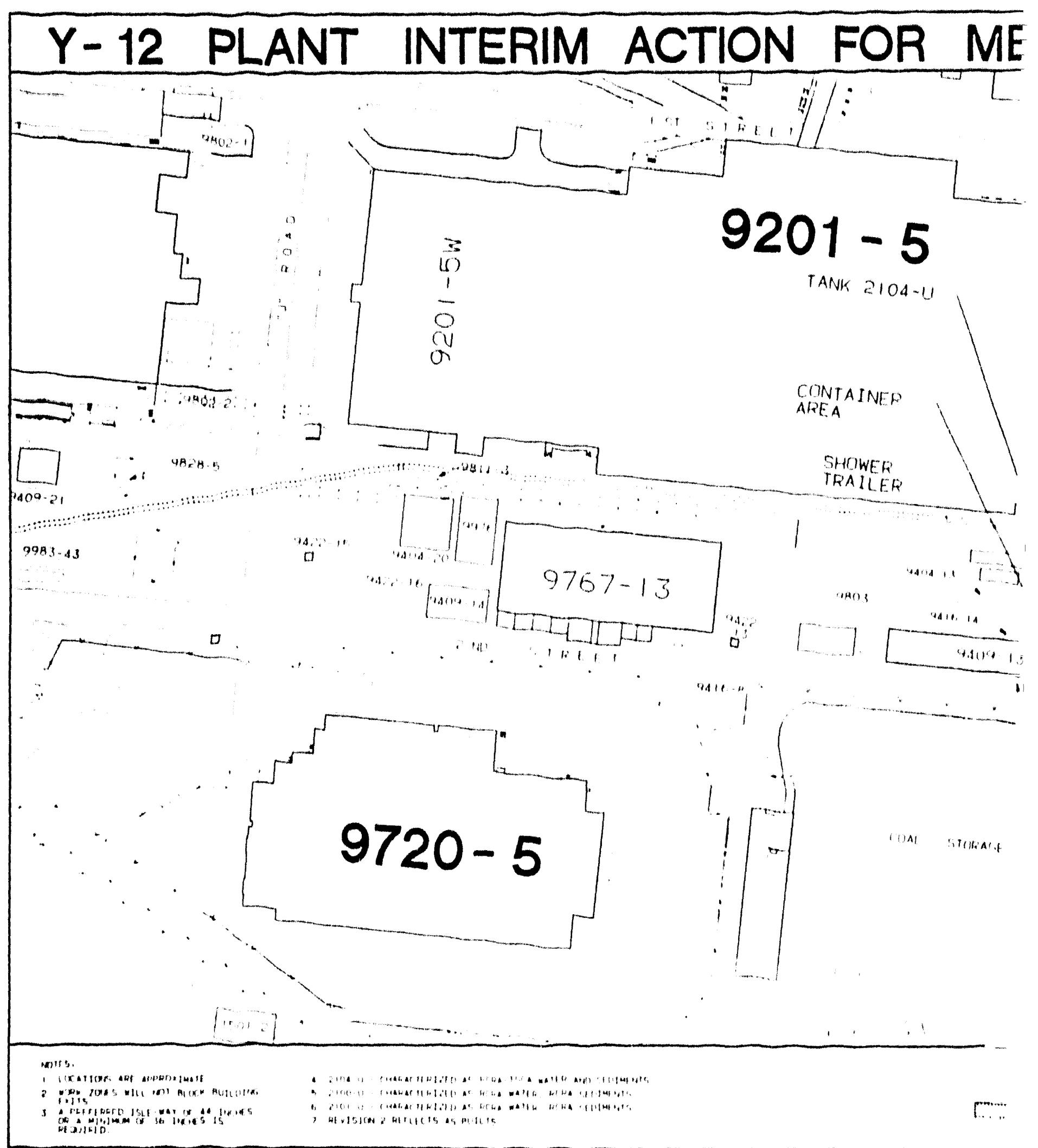

Fig. B.1. Y-12 Plant intcrim act 


\section{RCURY TANK CLEAN-OUT/WORK ZONES}

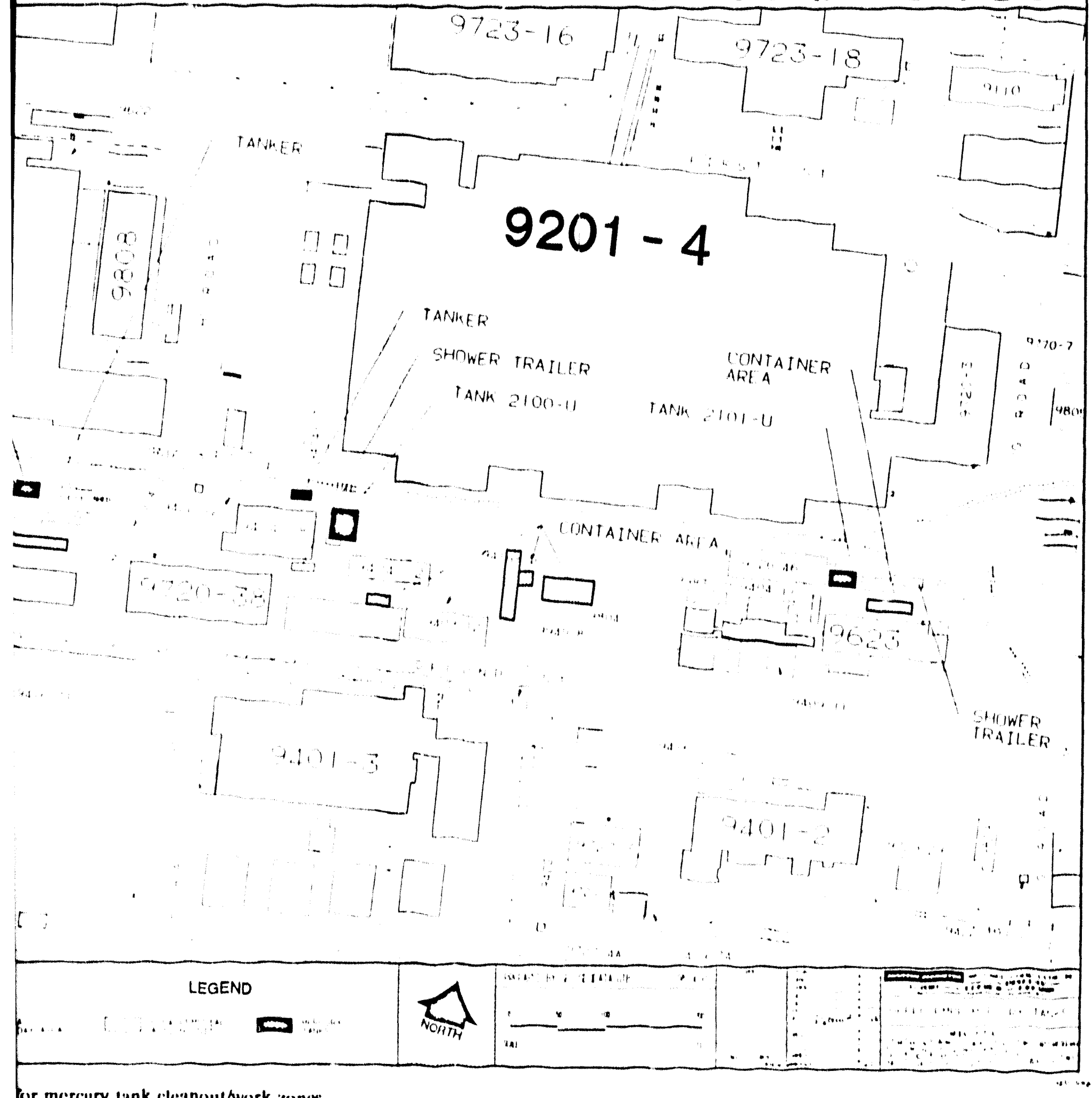

or mercury tank cleanout/work zoncs. 
B-7

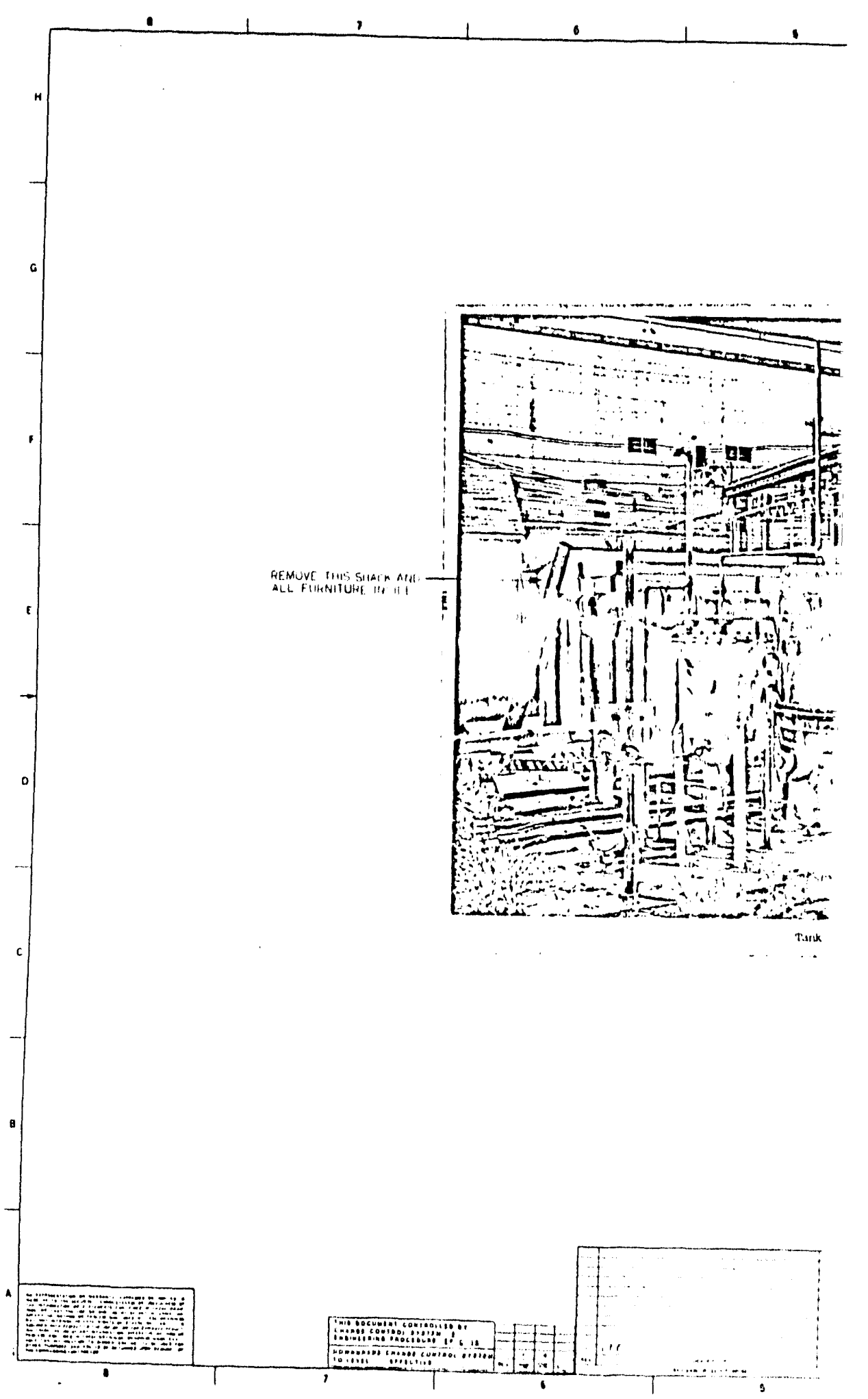

Fig. B.2. Tank clcanout, 210C 


\section{B-9}

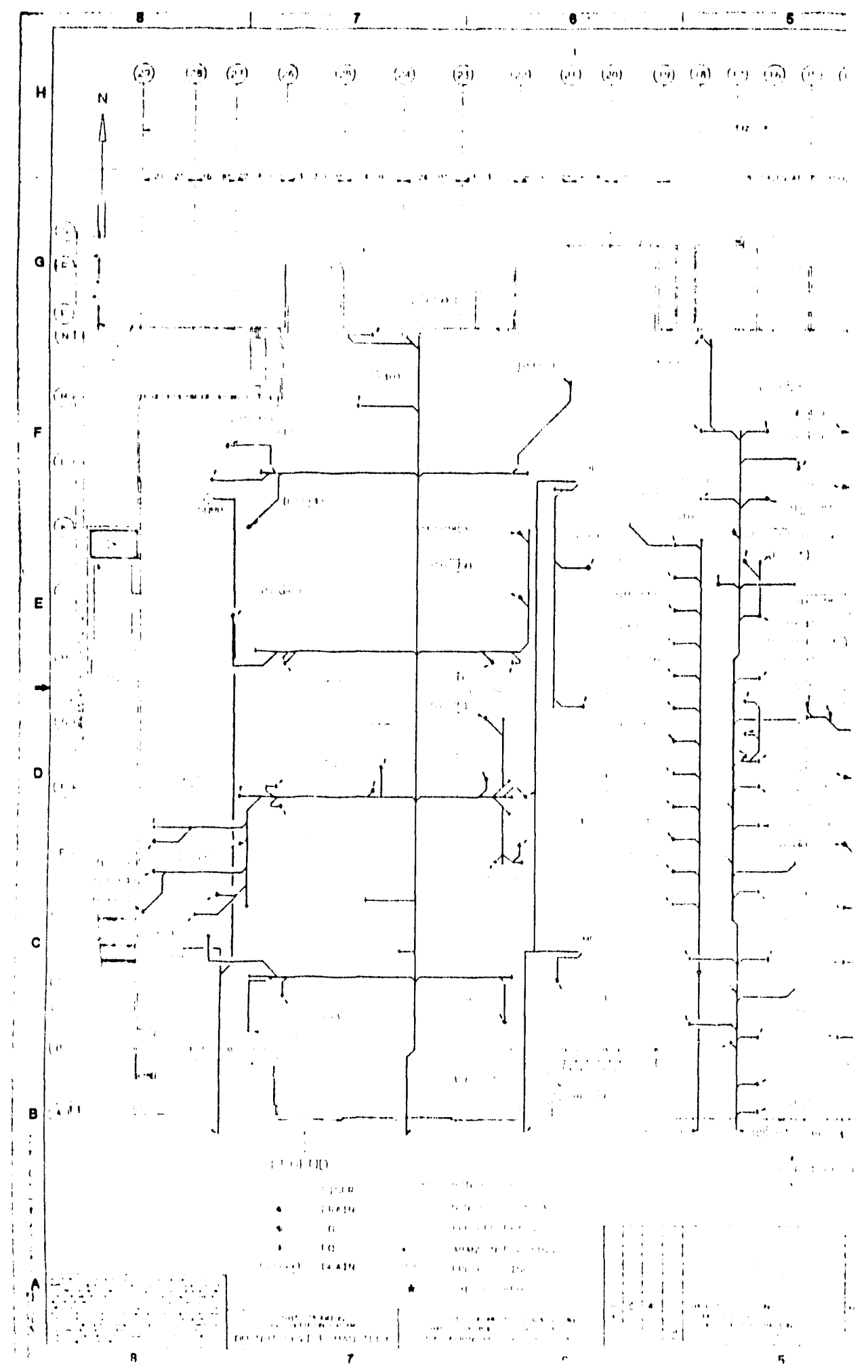

Fig. B.3. Floor and cquip 


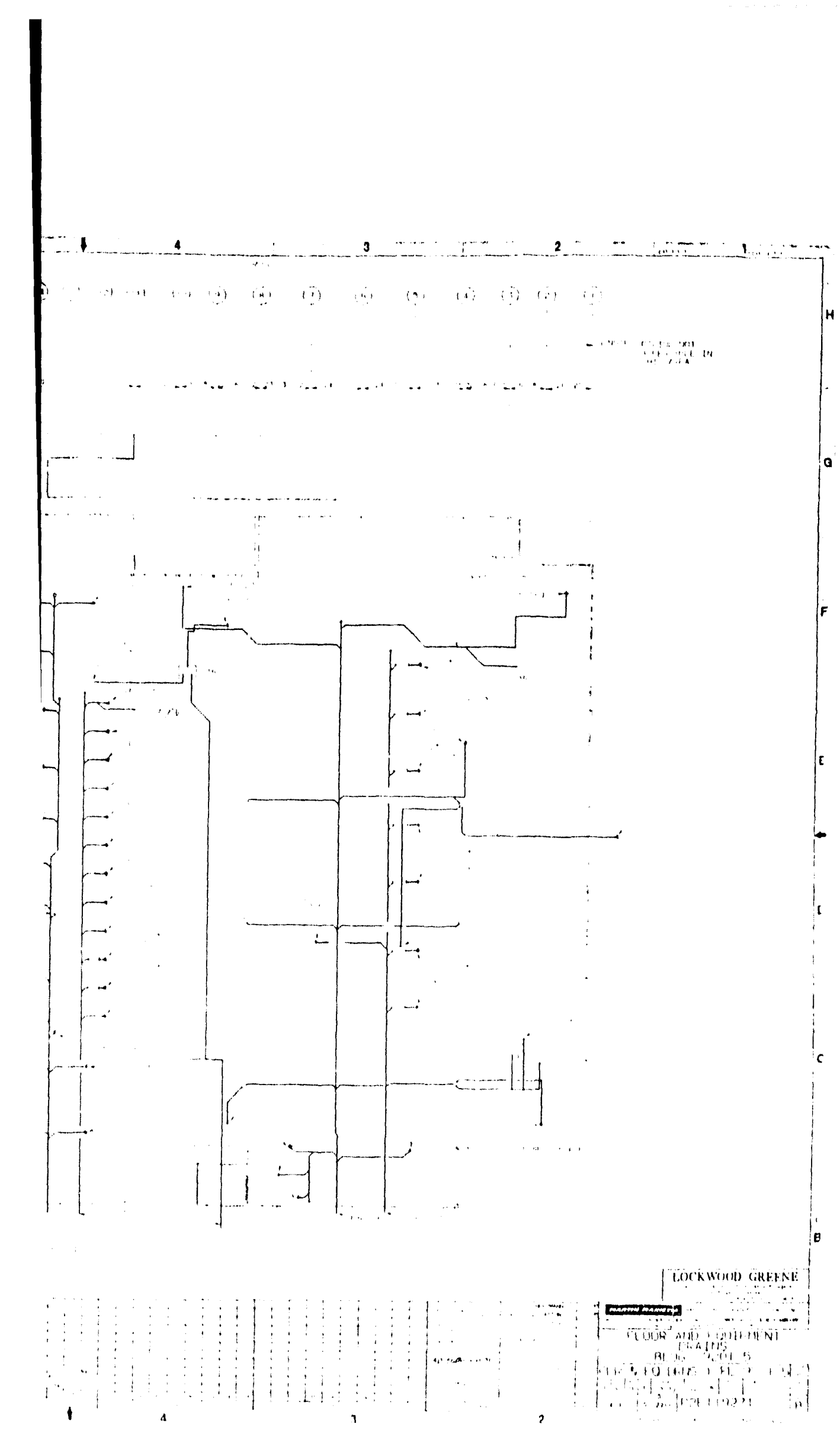

sent drains in Building 9201-5. 
Appendix C INSPECTION PLAN 


\title{
INSPECTION PLAN
}

\author{
for the \\ INTERIM ACTION for the Y-12 \\ PLANT MERCURY TANKS
}

November 1992 
November 6, 1992

Y/ER-4788

\section{INSPECTION PLAN}

for the

\section{Y-12 PLANT MERCURY TANKS \\ TANK INSPECTION PLAN}

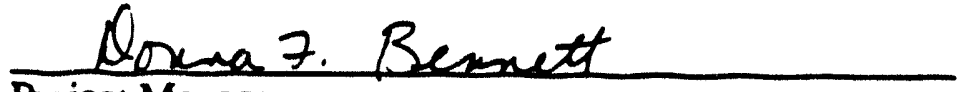

Project Manager
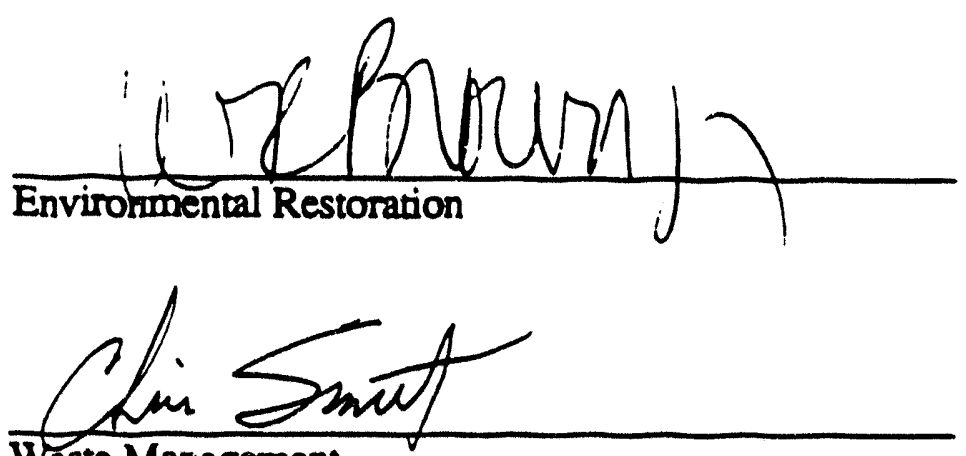

Waste Mariagement $\frac{11-11-92}{\text { Date }}$
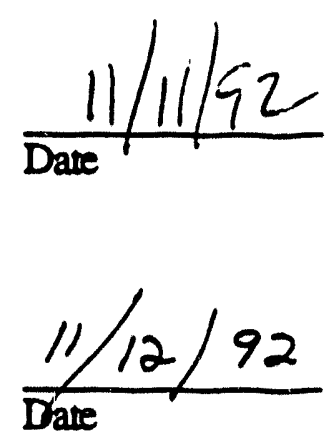


\section{CONTENTS}

INTRODUCTION $\ldots \ldots \ldots \ldots \ldots \ldots \ldots \ldots \ldots \ldots \ldots \ldots \ldots \ldots \ldots$

PART I TANK INSPECTION: SATISFACTION OF IROD CRTERIA $\ldots \ldots \ldots \ldots \ldots 1$

PART II TANK INSPECTION: DETERMINATION OF CURRENT TANK

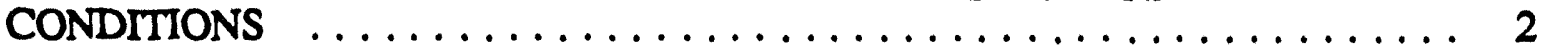

WASTE DRUM INSPECTION: EXAMINATION OF DRUMS FOR PRESENCE OF

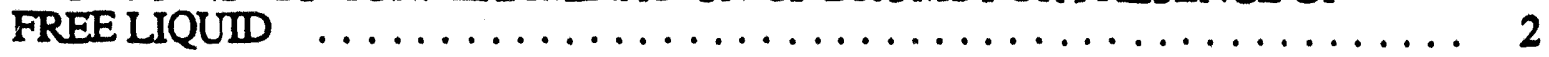

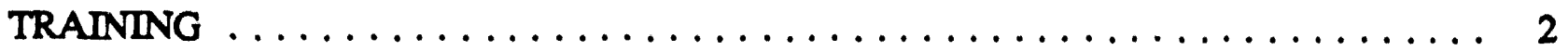

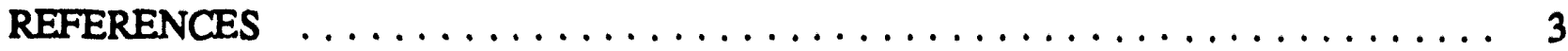

ATTACHMENT 1: TANK INSPECTION CHECKLIST $\ldots \ldots \ldots \ldots \ldots \ldots \ldots 4$

ATTACHMENT 2: WASTE DRUM INSPECTION CHECKLIST $\ldots \ldots \ldots \ldots \ldots 5$ 


\section{INTRODUCTION}

This document defines tank and waste drum inspection scope, requirements, and procedures for interim actions in the remediation of the $Y-12$ Plant Mercury Tanks project. This action is a subproject of the Upper East Fork Poplar Creek (UEFPC) Reduction of Mercury in Plant Effluent (RMPE) project. The "Remedial Action Work Plan: Interim Action for Y-12 Plant Mercury Tanks" (DOE/OR-1039\&D2) provides additional information on this project.

There will be two different purposes for tank inspection. Part I inspections will ensure that IROD criteria are met. Part II inspections will be performed to provide current information on the tanks. Part II is being performed as a best management practice and is not a regulatory requirement. requirements.

Waste drum inspection will be conducted to verify that the drums meet long-term storage

The subject tanks for this inspection plan are identified and located as follows:

- Tank 2100-U, southwest of Bldg 9201-4 in the Protected Area at Y-12

- $\quad$ Tank 2101-U, southeast of Bldg 9201-4 in the Protected Area at Y-12

- Tank 2104-U, southeast of Bldg 9201-5 in the Protected Area at Y-12

Reference drawing C2E900000A804, Rev. 0 for location detail.

These inspections will occur while MK-Ferguson is actively controlling these sites according to Hazardous Waste Operations (HAZWOPER) site access rules.

\section{PART I TANK INSPECTION: SATISFACTION OF IROD CRITERIA}

The three tanks will be inspected for the following conditions:

1. Presence of any standing liquid (water) in the tank.

2. Whether the tank floors and walls are broom clean.

3. Presence of any visible standing mercury in the tank.

4. Whether the piping inlets and outlets are clear of sediment.

Noncompliance with these requirements must be reviewed and approved by the MMES Project Manager and the DOE Project Manager.

The inspector will be the MMES Construction Engineer assigned to the project. MK-F shall assist in the inspection as required. The Tank Inspection Checklist (Attachnnent 1 at the end of this document) will be used to document these activities. 


\section{PART II TANK INSPECTION: DETERMINATION OF CURRENT TANK CONDITIONS}

The three tanks will be inspected for the following conditions:

1. Each tank will be given a complete internal and extemal visual inspection by MMES Equipment Testing and Inspection (ET\&I) per ET\&I Procedure Y 50-65-EI-012. ET\&I will supply written documentation of the conditions noted during their inspection within 5 days of their inspection. They will also supply recommendations to correct noted deficiencies.

2. The following measurements ( \pm 2 inches) shall be provided to reflect actual conditions for:

- internal tank dimensions;

- the locations and nominal pipe sizes of internal penetrations and piping inlets/outlets;

- the locations and sizes of all baffles; and

- the locations and sizes of all access ports.

A sketch of the tanks shall be provided to document this information.

3. Negatives and 8- $\times 10$-inch photographs of the inside of each tank shall be provided. These photographs shall show the interior baffles, all inlets/outlets, and any damaged areas within the tanks.

Activity 1 will be performed by MMES ET\&I with assistance from MK-Ferguson. Activities 2 and 3 will be performed by MK-Ferguson.

\section{WASTE DRUM INSPECTION: EXAMINATION OF DRUMS FOR PRESENCE OF FREE LIQUID}

After dewatering the drummed sediments, but before the drums are transported from the temporary storage or the 90 -day RCRA storage area, a minimum of $25 \%$ of the waste drums will be inspected to ensure that no standing water is visible in the drums. If free liquid is found, the MMES Project Manager will be notified.

This inspection will be performed by the MMES Construction Engineer with assistance from MMES WTSD personnel. The Waste Drum Inspection Checklist (Attachment 2 at the end of this document) will be used to document these activities.

\section{TRAINING}

All inspectors shall have training as required per Section 3.0 of the Best Management Practices Plan (Y/EN-4789). 
C-11

\section{REFERENCES}

Martin Marietta Energy Systems, Inc., "Best Management Practices Plan: Interim Action for the Y12 Plant Mercury Tanks," Y/EN-4789, 1992.

Martin Marietta Energy Systems, Inc., "Inspection of Storage Tanks," ET\&I Procedure Y50-65-EI$012,1992$.

Martin Marietta Energy Systems, Inc. "Remedial Action Work Plan: Interim Action for the Y-12 Plant Mercury Tanks," DOE/OR-1039\&D2 92-225-161-46, 1992. 


\section{ATTACHMENT 1: TANK INSPECTION CHECKLIST}
(1) Tank \#:
(2) Is standing liquid (water) present in the tank?
(3) Describe:

(4) Are the tank floors and walls broom clean?

(5) Describe:

(6) Is standing mercury visible in the tank?

(7) Describe:

(8) Are the piping inlets and outlets clear of sediment?

(9) Describe: 


\section{ATTACHMENT 2: WASTE DRUM INSPECTION CHECKLIST}

(1) Tank \#:

(2) Total number of drums:

(3) Total number of drums inspected:

(4) Percent of total drums inspected [(3)/(2)]:

(5) List identification \# of drums inspected:

(6) Total number of drums with free liquids:

(7) List identification \# of drums with free liquids: 
Appendix D

BEST MANAGEMENT PRACTICES PLAN 


\title{
BEST MANAGEMENT \\ PRACTICES PLAN
}

\author{
INTERIM ACTION
}

for the

\section{Y-12 PLANT MERCURY TANKS}

December 1992 


\section{DISCLAIMER}

Thls report was prepared as an account of work sponsored by an ageney of the Ualted States Governmeat. Nelther the Ualted States Goveratieat nor any agency thereof, nor any of thelr employees, makes any warranty, express or implied, or assumes any legel llablilty or responsibillty for the accuracy, completeacas, or usefulaess of apy laformation, apparatus, product, or process disclosed, or represents chat its ase would not infriage privately owned righte. Reference berato to any spectifc comberclal produch process, or service by trade name, tradenart, manufacturer, or otherwise, does not becessarliy constitute or Imply its eadorsemeal, recommendation, or favorias by the United Statea Goverameat or any azency thereof. The views and opinlons of authors expresaed herela do not neceasarily state or reneet those of the Unlted States Governmeat or any agency thereof. 
December 1992

D-5

Y/ER-4789/R1

\title{
BEST MANAGEMENT PRACTICES PLAN
}

\author{
INTERIM ICTION \\ for the
}

\section{Y-12 PLANT MERCURY TANKS}

Q.7. Bennet

Project Manager
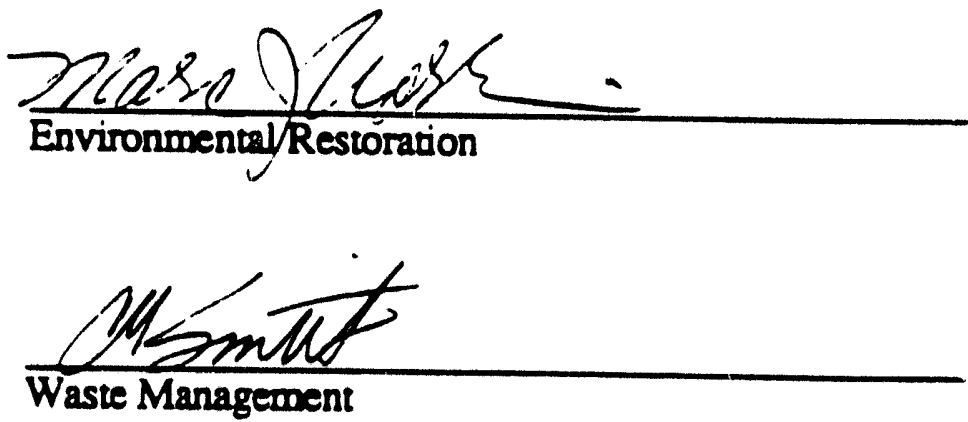

$\frac{12 \cdot 7-92}{\text { Dare }}$

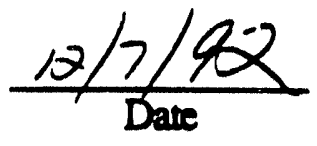

$\frac{12-7-92}{\text { Dare }}$ 
TABLE OF CONTENTS

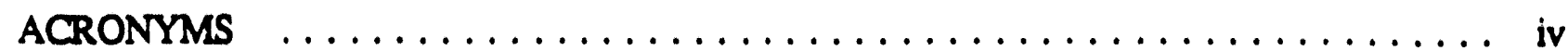

1. INTRODUCTION $\ldots \ldots \ldots \ldots \ldots \ldots \ldots \ldots \ldots \ldots \ldots \ldots \ldots \ldots \ldots$

2. FACILTYY DESCRIPTION $\ldots \ldots \ldots \ldots \ldots \ldots \ldots \ldots \ldots \ldots \ldots \ldots$

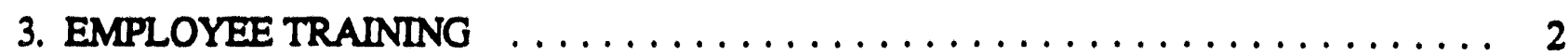

4. PRINCIPAL SAFETY, FIRE, AND HEALTH HAZARDS $\ldots \ldots \ldots \ldots \ldots \ldots 2$

5. SPILL PREVENTION AND CONTROL $\ldots \ldots \ldots \ldots \ldots \ldots \ldots \ldots \ldots \ldots$

6. WATER QUALTTY MONITORING $\ldots \ldots \ldots \ldots \ldots \ldots \ldots \ldots \ldots \ldots$

7. GOOD HOUSEKEEPING PRACTICES $\ldots \ldots \ldots \ldots \ldots \ldots \ldots \ldots$

8. INSPECTIONS AND ENVIRONMENTAL COMPLIANCE $\ldots \ldots \ldots \ldots \ldots \ldots$

9. WASTE MANAGEMENT DETAISS $\ldots \ldots \ldots \ldots \ldots \ldots \ldots \ldots$

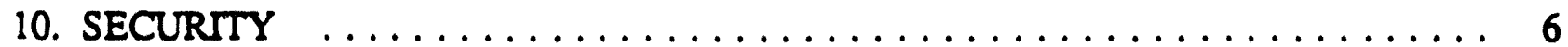

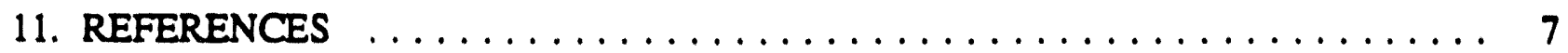

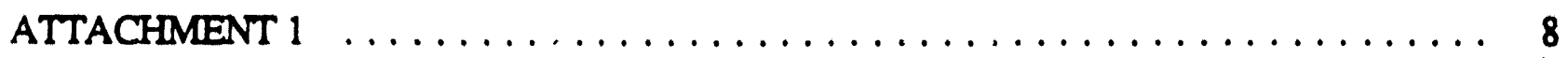


D.8

\section{ACRONYMS}

BMP $\ldots \ldots \ldots \ldots \ldots \ldots \ldots \ldots \ldots \ldots$ Best Management Practices

CFC $\ldots \ldots \ldots \ldots \ldots \ldots \ldots \ldots \ldots \ldots \ldots$ Certified for Construction

CFR ............................... Code of Federal Regulations

DOE $\ldots \ldots \ldots \ldots \ldots \ldots \ldots \ldots \ldots \ldots \ldots \ldots \ldots \ldots$. . . . . . . . . . . . . . . . . Enent of Engy

IROD . . . . . . . . . . . . . . . . . . . . . . . . Interim Record of Decision

MMEES $\ldots \ldots \ldots \ldots \ldots \ldots \ldots \ldots \ldots \ldots \ldots \ldots \ldots \ldots \ldots \ldots \ldots$ Martin Marietta Energy Systems

NFPA . . . . . . . . . . . . . . . . . . . . National Fire Protection Association

NPDES . . . . . . . . . . . . . . National Pollutant Discharge Elimination System

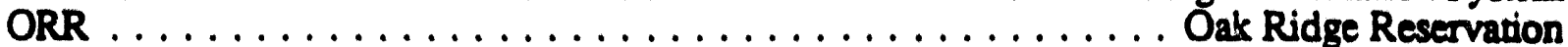

PCBs $\ldots \ldots \ldots \ldots \ldots \ldots \ldots \ldots \ldots \ldots \ldots \ldots$ polychlorinated biphenyls

RMPE $\ldots \ldots \ldots \ldots \ldots \ldots \ldots \ldots \ldots \ldots$ Reduction of Mercury in Plant Effluent

SPCC $\ldots \ldots \ldots \ldots \ldots \ldots \ldots$. . . . . . Spill Prevention Control and Countermeasures

UEFPC . . . . . . . . . . . . . . . . . . . . . . . . . . . . . . . . Upper East Fork Poplar Creek

USEPA $\ldots \ldots \ldots \ldots \ldots \ldots \ldots \ldots$ United States Environmental Protection Agency

WTO . . . . . . . . . . . . . . . . . . . . . . . . . . . Waste Treatment Operations

WTSD ..................... Waste Transportation, Storage and Disposal 


\section{INTRODUCTION}

The purpose of this document is to provide a site-specific Best Management Practices (BMP) Plan for the Interim Action for the Y-12 Plant Mercury Tanks project. This action is a subproject of the Upper East Fork Poplar Creek (UEFPC) Reduction of Mercury in Plant Effluent (RMPE) project. The "Remedial Action Work Plan: Interim Action for Y-12 Plant Mercury Tanks" (DOE/OR-1039\&D2) provides additional information on this project.

A storm water sewer system drains the Y-12 Site and discharges directly to UEFPC. Tied into the storm sewer system are three underground concrete settling tanks (2100-U, 2101-U, and 2104-U) that receive flow from basement sumps in Buildings 9201-4 and 9201-5. As a result of past spills and waste water discharges, these tanks contain materials contaminated with mercury, uranium, and polychlorinated biphenyls (PCBs).

Section 304(e) of the Clean Water Act enables the Administrator of the United States Environmental Protection Agency (USEPA) to control point source releases of pollutants. The National Pollutant Discharge Elimination System (NPDES) requires that facilities with the potential for releasing pollutants to the waters of the United States submit a BMP Plan, as specified in 40 CFR 125, Subpart K, as a part of the discharge permit application.

According to the Martin Marietra Energy Systems, Inc. (MMES) Environmental and Waste Management Policy (ESH-14), "It is company policy to establish and to maintain waste management pollution control, and surveillance programs which are consistent with the company and DOE policy and which meet the requirements of federal, state, and local regulations to assure that installacion personnel, the general public, and the environment are protected against hazardous pollutants."1

Implementation of the BMP Plan will be initiated by providing a copy to all parties involved in the Interim Remedial Actions activities. To ensure compliance with the provisions of this plan', formal site inspections will be made and recorded by the ES Construction Engineer.

\section{FACILITY DESCRIPTION}

The Y-12 Plant is located on the United States Department of Energy (DOE) Oak Ridge Reservation (ORR) in Anderson and Roane counies, approximately 24 miles west of the city of Knoxville. The Tennessee Valley Authority's Melton Hill Reservoir on the Clinch River forms the southern and western boundaries of the reservation, and the city of Oak Ridge is on the northem boundary. Buildings 9201-4 and 9201-5 are located along Second Street, in the western "Protected" area of the Y-12 Plant. Tank 2100-U is located outside and just southwest of Building 9201-4. Tank 2101-U is located outside and just southeast of Building 9201-4. Tank 2104-U is located outside and just southeast of Building 9201-5.

The scope of work for this project will involve three primary steps:

- removal of oil and oily water from Tank 2101-U;

- removal of water from all three tanks; and 
D. 10

- removal and dewatering of mixed waste sediments from all three tanks.

Appropriate inspections will provide verification of the above steps (see separate Inspection Plan, Y/EN-4788).

\section{EMPLOYEE TRAINING}

MDMES employees receive a broad range of environmental, health, and safety training based on their job requirements. Environmental awareness is raised by issuing periodic bulletins concerning topics such as spill control. Supervisors are responsible for providing on-the-job training with respect to hazardous materials handling and company environmental policy.

Contractors/ subcontractors performing work at the three subject Tanks (2100-U, 2101-U, and 2104-U) will be required to comply with DOE and MMES Environmental Policy, including the provisions of this BMP Plan. Contractor/ subcontractors are responsible for their employees' training. The contractor is to perform the work as specified in the Cerrified for Construction (CFC) drawings and specifications, project plans, and the Remedial Action Work Plan.

As the tank sites are defined as HAZWOPER sites, all visitors to the site shall have received HAZWOPER training and uny training specific to $Y-12$ requirements prior to visiting the site. In addition, workers that will be entering the tanks shall have received Confined Space training as well as the proper Respirator training.

\section{PRINCIPAL SAFETY, FIRE, AND HEALTH HAZARDS}

System and equipment selections shall be compatible with existing facilities and shall conform to Y-12 safety requirements. Use of the latest editions of applicable codes is required.

Standard health and safety procedures shall be established by the contractor for work at the project site, including a Site Specific Health and Safety Plan that meets all applicable DOE, Y-12, OSHA, and USEPA requirements. The plan shall detail a Site Health and Safety Officer and site organization, specify expected hazards, required training and medical surveillance, exposure monitoring, work zone establishment and safe working practices, protective clothing and equipment, contamination control, and emergency response.

\section{SPILL PREVENTION AND CONTROL}

The Spill Prevention Control and Countermeasures (SPCC) Plan for the Y-12 Plant2 provides details concerning roles and responsibilities of employees.

Y-12 has a Spill Control Commitree as required by Section 402 of the Clean Water Act. The committee is composed of representatives from all plant functions and is charged with the responsibility of development and oversight of the Spill Prevention Program. The number and type of spills and lessons leamed are discussed each month during the Environmental Officers Meeting. 
The Y-12 Spill Prevention Program requires that all possible precautions be taken to minimize the likelihood of a spill. Guidelines for design and construction of hazardous material storage tanks and secondary containment are specified in the MMIES document Design Standards for Hazardous/Toxic Waste and Material Storage Tanks, Dikes and Transfer Stations, Y/TS-104.3

All containers over 5 gallons are required to be labeled with the appropriate Hazardous Identification Label (diamond) as identified in the National Fire Protection Association (NFPA) Code (NFPA-704.) 4

If a spill occurs at the work zones, all safe, practical methods should be used to prevent material from entering outfall pipelines, streams, ponds, or springs. Spills should be reported immediately per the procedure outlined in the Y.12 SPCC Plan. Spill response tits containing absorbent material will be provided at the site. Absorbent pillows, temporary earth dikes, or other means should be readily available on-site and employed as appropriate, without risting personnel safery. Materials spilled by contractor, if any, will be cleaned up daily, placed in appropriate containers, and disposed of in accordance with Y.12 Waste Operations Procedures through the Construction Engineer.

Provide the following information (if requested) whe. a spill occurs:

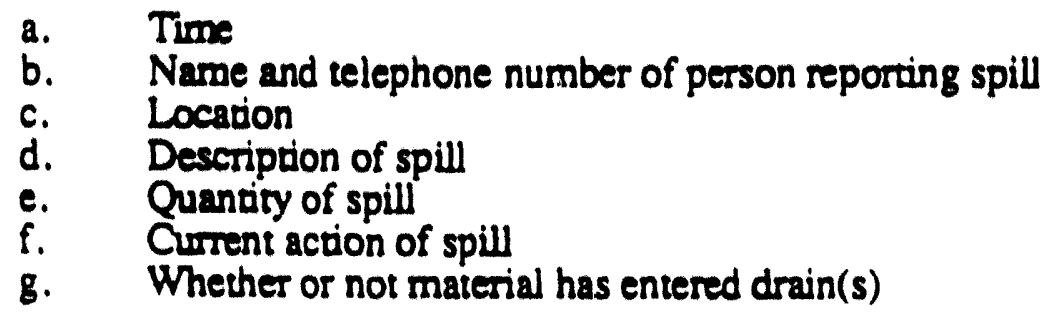

\section{WATER QUALITY MONITORING}

Water quality monitoring is an on-going activity as part of the NPDES permit.

\section{GOOD HOUSEKEEPING PRACTICES}

Good housekeeping practices will be observed by all personnel present inside or outside the project work zones at all times. Paper trash and refuse will be contained, collected, and disposed of at an appropriately permitted facility. No unpermitred waste water of any type will be discharged on-site. All rinse water containing additives of any kind (i.e., soap, degreasers, cleaning agents) will be contained, collected, and disposed of in accordance with the appropriate plant waste disposal procedure. Trucks hauling material on- and off-site will not be overfilled. Loose debris will be contained within the vehicles to prevent littering of highways and haul roads.

Appropriate precautions are to be taken to minimize discharge of fuel, oil, lubricants, grease, and other hydrocarbons. 


\section{INSPECTIONS AND ENVIRONMENTAL COMPLIANCE}

Weekly site inspections during the construction activities will be made by the Construction Engineer to confirm compliance with all environmental regulations and policies, including those set forth in the BMP Plan. A writen record, including the date and findings of the inspection and notification of the appropriate party, will be kept in the office of the Construction Engineer.

In addition, periodic site inspections will be made by the Health \& Safety Division and/or Industrial Hygiene personnel to confirm compliance with all environmental regulations and policies, including those set forth in the BMP Plan. A written record, including the date and findings of the inspection and notification of the appropriate party, will be kept in the office of the Health \& Safety Division or Industrial Hygiene office, respectively.

Items to be inspected include, but are not limited to, the following:

- General housekeeping on-site

- Spill prevention and control measures

- Evidence of leaking tanks or equipment

- Inspection of creek headwaters for oil sheen, debris, or other disturbance.

\section{WASTE MANAGEMENT DETAILS}

The Waste Management Plan (DOE/OR-1039\&D2) details the waste management criteria for this project. Additional details are provided here for specific waste handling and managemont.

\section{General Waste Details}

All waste water that will be sent to Waste Treatment Operations (WTO) for treatment shall be pumped by MK-F through at least a 10-micron filter. Waste Transportation, Storage and Disposal (WTSD) will transpor all waste. Waste water will be transported only after it has been sampled by WTSD Sampling personnel and the results of analysis have been received.

Each tank will have at least two UCN-2109 forms: one for the waste water, and one for the waste sediments. Additional UCN-2109 forms will be required for miscellaneous debris and decontamination and shower waste water. All UCN-2109 forms will be completed by MMES personnel.

Containers that are considered non-reusable, such as drums, must also be labeled with a container bar code and the UCN-2109 section of the bar code affixed to the UCN-2109 form. 
Tank 2104-U. Waste water from 2104-U shall be transferred by MK-F to WTSD. provided tanker(s). This tanker will be located in the 90-day RCRA storage area. A UCN-2114A label will be attached to the tanker by the 90-day RCRA operator or alternate (MMES). The waste water will be transported in the tanker to the appropriate WTO waste water treament facility by WTSD.

Decontamination waste water shall be stored in a polytank(s) supplied by WTSD and located in the temporary storage area. A UCN-2114A label will be attached to the polytank by the 90-day RCRA operaror or alternate (MMES) the first day decon water is added to the polytank. The polytank(s) will be transported to the appropriate WTO waste water treatment facility by WTSD.

MR.F shall store shower waste water in a polytank provided by WTSD. A $2114 \mathrm{~B}$ label shall be attached to the polytank by MK-F. WTSD will transport the waste water for treatment at the appropriate WTO waste water treatment facility.

Tank 2100-U. Waste water from 2100-U shall be transferred by MK-F to the WTSD. provided tanker(s). This tanker will be located in the 90-day RCRA storage area A UCN-2114A label will be attached to the tanker by the 90-day RCRA operator or alternate (MMES). The waste water will be transported in the tanker to the appropriate WTO waste water treaconent facility by WTSD.

Decontamination waste water shall be stored in a polytank(s) supplied by WTSD and located in the 90-day RCRA storage area. A UCN-2114A label will be attached to the polytank by the 90-day RCRA operator or altemate (MMES) the first day decon water is added to the polytank. The polytank(s) will be transported to the appropriate WTO waste water treament facility by WTSD.

MK-F shall store shower waste water in a polytank provided by WTSD. A 2114B label shall be attached to the polytank by MK.F. WTSD will transport the waste water for treacment at ' the appropriate WTO waste water treatment facility.

Tank 2101-U. The oily phase and waste water removed from 2101-U shall be transferred by MK-F into WTSD-provided tuff tank(s). This tank will be located in the 90-day RCRA storage area. A UCN-2114A label will be arrached to the tank by the 90-day RCRA operator or alternate (MMES). WTSD will transport the ruff tank to appropriate storage for later disposal at the Toxic Substances Control Act incinerator.

Decontamination waste water shall be stored in a polytank(s) supplied by WTSD and located in the 90-day RCRA storage area. A UCN-2114A label will be attached to the polytank by the 90-day RCRA operator or alternate (MMES) the first day decon water is added to the polytank. The polytank(s) will be transported to the appropriate WTO waste water treatment facility by WTSD.

MK-F shall store shower waste water in a polytank provided by WTSD. A UCN-2114B label shall be atrached to the polyrank by MK-F. WTSD will transpor the waste water for trearment at the appropriate WTO waste water treatment facility. 


\section{Sediment Waste Details}

Atachment 1 consist of Drum Management Plan flow diagrams to enhance the explanation of waste handling of the tank sediments. Each step is detailed as follows:

1. MK-F shall fill the drums $3 / 4$ full with the sediments from the tank. The drum shall then be sealed with a drum lid and a plastic drum lid cover by MK-F personnel. For RCRA sediments, the 90-day RCRA operator or alternate (MMIES) will then attach the UCN$2114 A$ label. For non-RCRA sediments, MK-F shall attach the UCN-2114B label.

2. MK-F shall then reposition/transfer the drum to the diked storage area.

3. The drums should sit for approximately three days to allow liquids to separate from the sediments.

4. MK-F shall remove the drum lid and, using a drum pump, decant water from the sediments into a polytank provided by WTSD. The polyrank will be labeled with a UCN-2114A label by the 90-day RCRA operator or alternate (MMES).

5. MK-F shall mix absorbent material to the sediments with a shovel until sediments are dry.

6. MK-F shall add the Condensation Pad and reseal the drum with the lid and plastic cover.

7. Allow drum to sit for approximately 3 or 4 days.

8. MMES CE will inspect a percentage of drums for dryness following guidelines in Inspection Plan (Y/EN-4788). The CE will be assisted by WTSD with this effort.

9. Upon successful inspection results, WTSD will transport drums to Treatment, Storage, Disposal facilities.

\section{SECURITY}

As the subject tanks for this project are located in the Protected Area of the Y-12 Facility, all personnel worting at the site will have received the appropriate Security Clearances to allow entry into the Protected Area; or, if uncleared, they will enter the Protected Area accompanied by an approved escor. 


\section{D.15}

\section{REFERENCES}

1. Martin Marietta Energy Systen's, Inc., Environmental and Waste Management Policy, ESH14, May 1985, 6 pp.

2. Martin Marietta Energy Systems, Inc., Spill Prevention Control and Counuermeasures (SPCC) Plan for the Y.12 Plant (1990 Revision), 1990, $170 \mathrm{pp}$.

3. Martin Marietta Energy Systems, Inc., Design Standards for Hazardous/Toxic Waste and Materials Storage Tanks, Dikes, and Transfer Stations, Y/TS-104, 1985, 20 pp.

4. National Fire Protection Association. "Standard System for the Identification of the Fire Hazards of Material," NFPA_704, 1961.

5. Martin Marietta Energy Systems, Inc., "Remedial Action Work Plan: Interim Action for the Y-12 Plant Mercury Tanks", DOE/OR-1039\&D2 92-225-161-46, 1992. 


\section{Drum Management Plan}
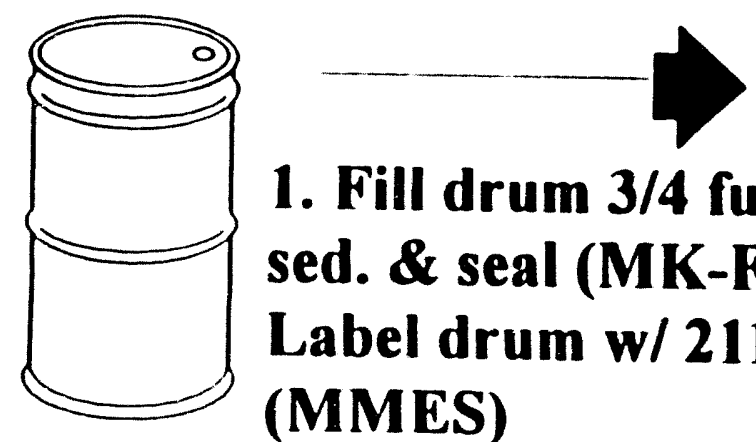

1. Fill drum $3 / 4$ full with sed. \& seal (MK-F)

Label drum w/ 2114A (MMES)

$\infty$

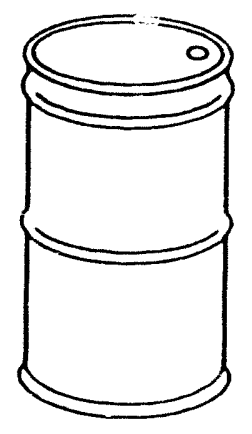

4. Decant water from sediments (MK-F)

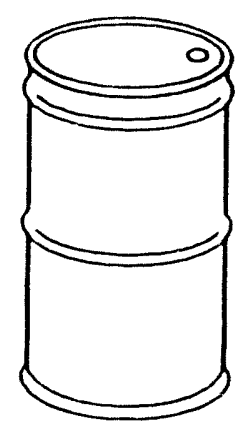

2. Transfer to temporary storage area (MK-F)
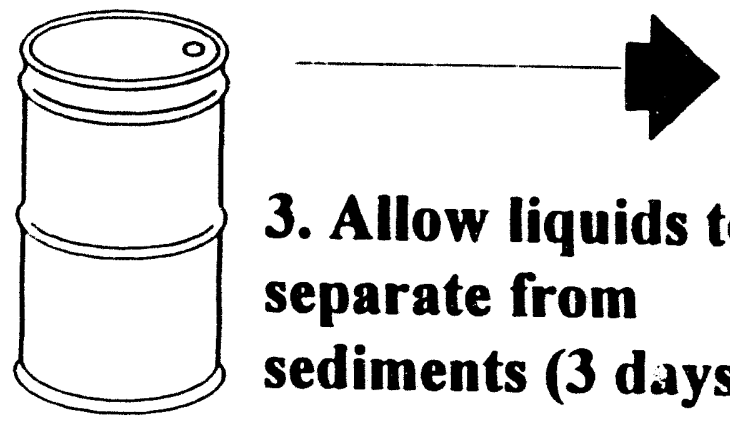

3. Allow liquids to separate from sediments (3 days)

5. Mix absorbal to sediments (MK-F)

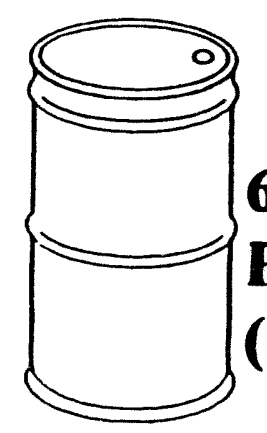

6. Add Condensation Pad and Reseal (MK-F)

7. Wait 3 or 4 days

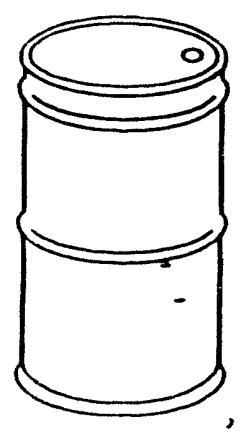

8. Inspect drum for dryness (MMES)

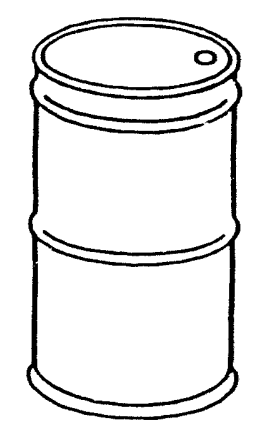

9. Transport to TSD storage facility (MMES) 
UEFPC RMPE Mercury Tank 2100-U

\section{Drum Management Plan}

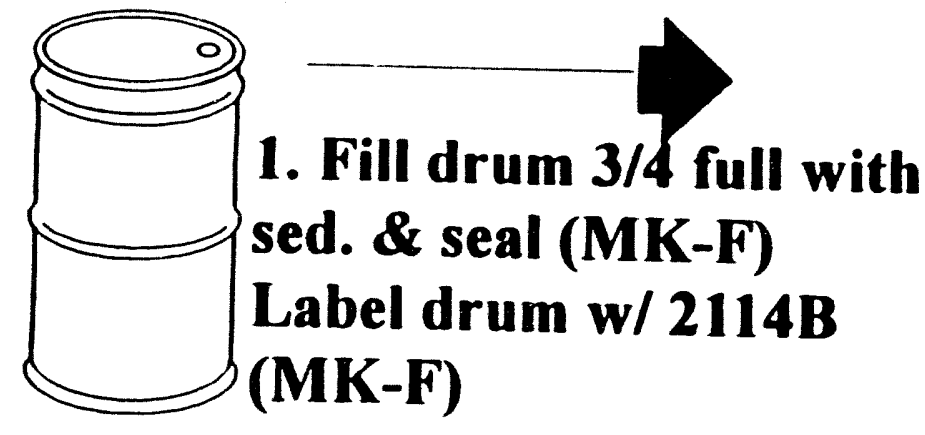

$\infty$

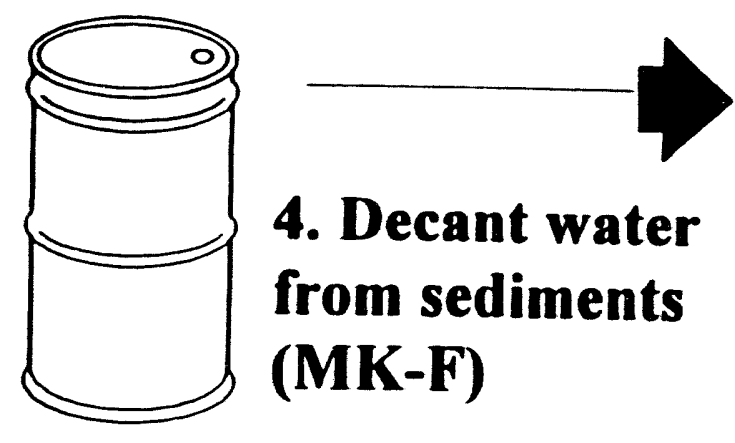

7. Wait 3 or 4 days

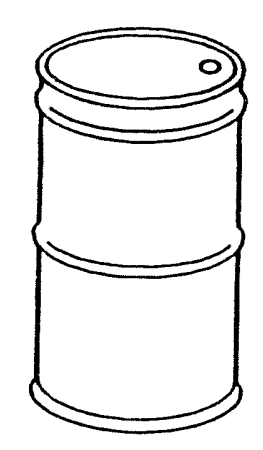

2. Reposition within 90 day RCRA storage area (MK-F)
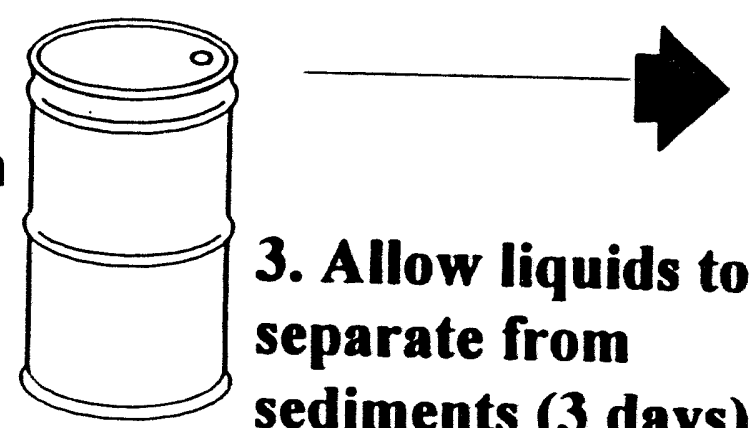

3. Allow liquids to separate from sediments ( 3 days)
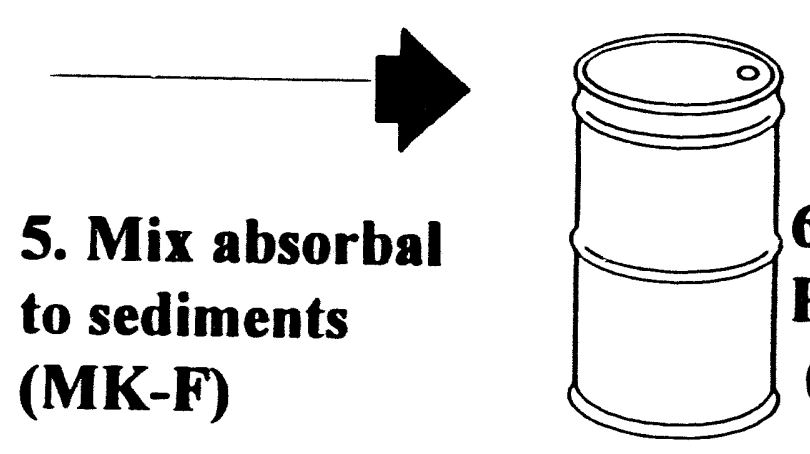

6. Add Condensation Pad and Reseal (MK-F)

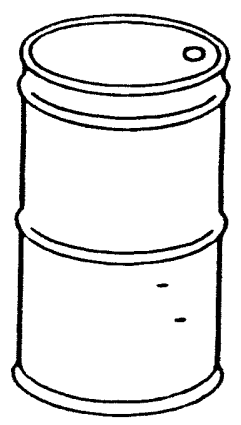

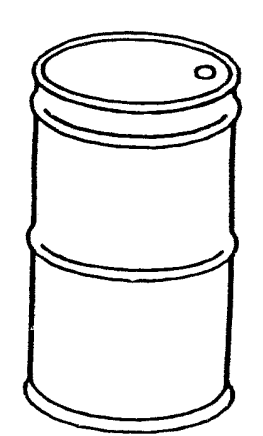

9. Transport to TSD storage facility (MMES) 


\section{UEFPC RMPE Mercury Tank 2101-U Drum Management Plan}

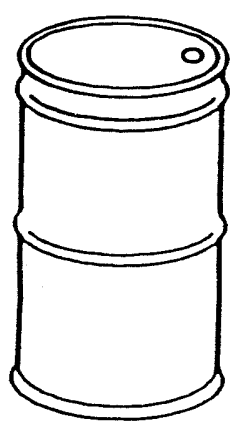

1. Fill drum $3 / 4$ full with sed. \& seal (MK-F) Label drum w/ 2114B (MK-F)

$\rightleftarrows$

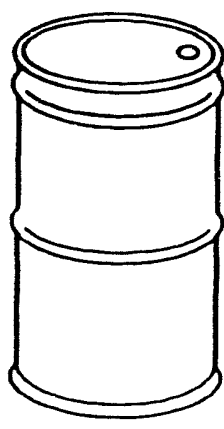

4. Decant water from sediments (MK-F)

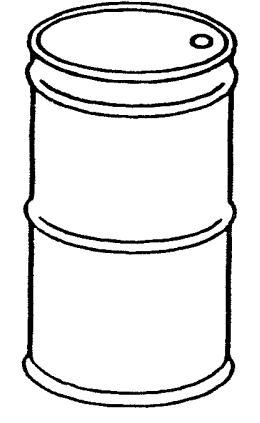

5. Mix absorbal to sediments (MK-F)

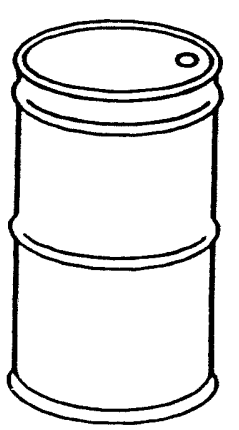
Pad and Reseal
3. Allow liquids to separate from sediments ( 3 days)

2. Transfer to 90 day RCRA storage area (MK-F)

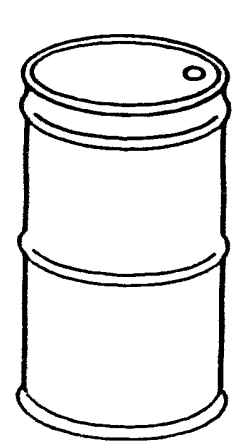

6. Add Condensation (MK-F)

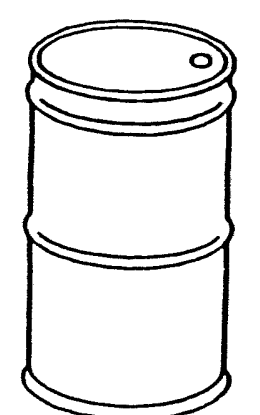

9. Transport to TSD

8. Inspect drum for dryness (MMES) storage facility (MMES) 
Appendix E

MODIFIED WASTE MANAGEMENT PLAN 


\section{Environmental Restoration Waste Management Plan}

1. Project Name: Interim Action for the Y-12 Mercury Tanks

Revision No.: 2

Plant: Y-12

Date: February 1993

Organization: Y-12 Environmental Restoration

Subproject of: UEFPC Reduction of Mercury in Plant Effluent

2. Responsible Project Manager: Donna F. Bennett

3. Expected Start/Completion Dates: December 1992/April 1993

4. Project Deacription (brief): Contaminated sediment and water will be removed from 3 concrete tanks. The sediment will be dewatered and placed into long-term storage. The wastewater will be treated at a wastewater treatment facility operated by Y.12 Waste Treatment Operations (WTO). An oily phase will be placed into bulk storage by Y-12 Waste Transportation. Storage, and Disposal (WTSD) for later disposal.

5. Project Participants (for waste management interface only):

Waste Generation: Y-12 Environmental Restoration

Waste Handling: MK-Ferguson

Waste Transportation: Y-12 WTSD (Chuck Eblen)

Waste Treatment: Y-12 WTO (Angela Fleming)

Waste Storage: WTSD (Mary Wiginton)/K-25 Storage (Gary Conner )

\section{Waste Generation:}

\begin{tabular}{|c|c|c|c|c|}
\hline Material & Type/Category & Volume & Destination & $\begin{array}{c}\text { Possible } \\
\text { Contaminants }\end{array}$ \\
\hline shack & solid/clean & $400 \mathrm{ft}^{3}$ & landfill & \multirow[t]{3}{*}{ none } \\
\hline pipes and valves & $\begin{array}{l}\text { solid/TBD by } \\
\text { waste } \\
\text { characterization }\end{array}$ & $100 \mathrm{ft}^{3}$ & $\begin{array}{l}\text { decontaminate at } \\
\text { site, then to } Y-12 \\
\text { scrap yard }\end{array}$ & \\
\hline $\begin{array}{l}\text { miscellaneous } \\
\text { equipment }\end{array}$ & solid/clean & $50 \mathrm{ft}^{3}$ & TBD & \\
\hline wastewater & liquid/mixed & $13,750 \mathrm{gal}$ & WETF & \multirow{5}{*}{$\begin{array}{l}\text { uranium, } \\
\text { mercury, and } \\
\text { eys }\end{array}$} \\
\hline oil & liquid/mixed & $1,310 \mathrm{gal}$ & $\begin{array}{c}\text { store in OD.9 at } \\
Y .12\end{array}$ & \\
\hline sediments & solid/mixed & $800 \mathrm{ft}^{3}$ & K-25 storage & \\
\hline $\begin{array}{l}\text { decontamination } \\
\text { fluid }\end{array}$ & liquid/mixed & $500 \mathrm{gal}$ & WETF & \\
\hline $\begin{array}{l}\text { contaminated } \\
\text { protective clothing, } \\
\text { debris, and } \\
\text { equipment }\end{array}$ & solid/mixed & $700 \mathrm{ft}^{3}$ & K-25 storage & \\
\hline
\end{tabular}




\section{Environmental Restoration Waste Management Plan}

7. Waste Analyais and Characterization: Multiple grab samples were taken of the sediment and water, and these were analyzed for metals (the TCLP was used), volatiles, semi-volatiles, total $\mathrm{Hg}_{\mathrm{g}} \mathrm{PCBs}$, total $\mathrm{U}$, and $\% \mathrm{U}^{235}$. The results showed that the samples do not fail the TCLP for mercury, even though there are high levels of total mercury. Likewise, the sediment and water concentrations of PCBs fall within the range of $2-49 \mathrm{ppm}$, a level classified as "PCB detectable" and not subject to the storage requirements of TSCA. At the treatment facilities, treatment studies were performed. The results of these tests indicated no problems in the proper treatment of wastes.

8. Waste Staging Area: A staging area for filling polytanks, drums, or tankers will be set up within the work zone. Liquid containers will have adequate secondary containment provided, while waste drums will be placed on pallets with adequate aisle space to allow inspections. Additionally, containers for holding contaminated personnel protection equipment and miscellaneous debris will be staged in the work zone near the decontamination station. Containerized waste will be stored in a storage area prior to transporting to K-25.

9. Transport Across Public Roads Required? Yes. The transportation route will run from the intersection of Bear Creek Road and Highway 58, north to the intersection of Highway 95 and Highway 58, then west to Blair Road, and finally to the Portal 5 entrance to K-25. DOT regulations apply to packaging and marking of containers and placarding of vehicles.

10. Waste Storage Requirements:

90-Day RCRA Storage Area: one such area at the site of each tank

Responsible Organization: Y-12 ERMMK-F

Permitted Storage: Waste Management Storage Area at K-25

Responsible Organization: K-25 Waste Management

11. Identification of Potential Treatment Options:

Location: Y.12 waste water treatment facilities

Responsible Organization: Y.12 WTO

12. Identification of Potential Disposal Options:

Location: K-25 TSCA Incinerator

Responsible Organization: Y.12 WTSD/K-25 WMO

13. Waste Minimization and Reduction Techniques To Be Implemented:

segregation - separate non-hazardous trash and debris from contaminated material

compaction - compactible material will be reduced in volume as much as practical

dewatering - to minimize the addition of absorbent material, sludge will be dewatered to a level acceptable by the storage facility 
E-5

Environmental Restoration

Waste Management Plan

14. Additional Information: WTO required that 10-micron filters be used to filter suspended solids from wastewater when pumping wastewater to transport vessels. Y-12 ER will establish waste stream profiles for all material removed during this project. Y-12 WTSD will coordinate disposal or storage and provide transportation of waste materials, including tankers or polytanks for handling liquid wastes. The Y.12 ER Waste Coordinator will coordinate WTSD support for this effort.

Approvals:

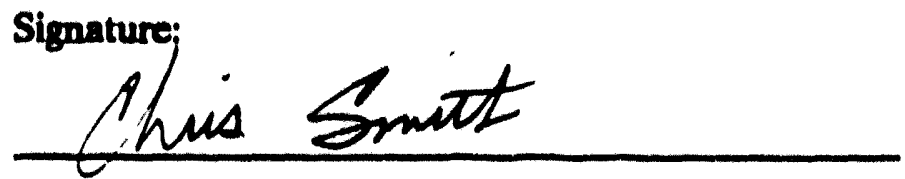

Plant ER Waste Management

Plant Waste Management Division:
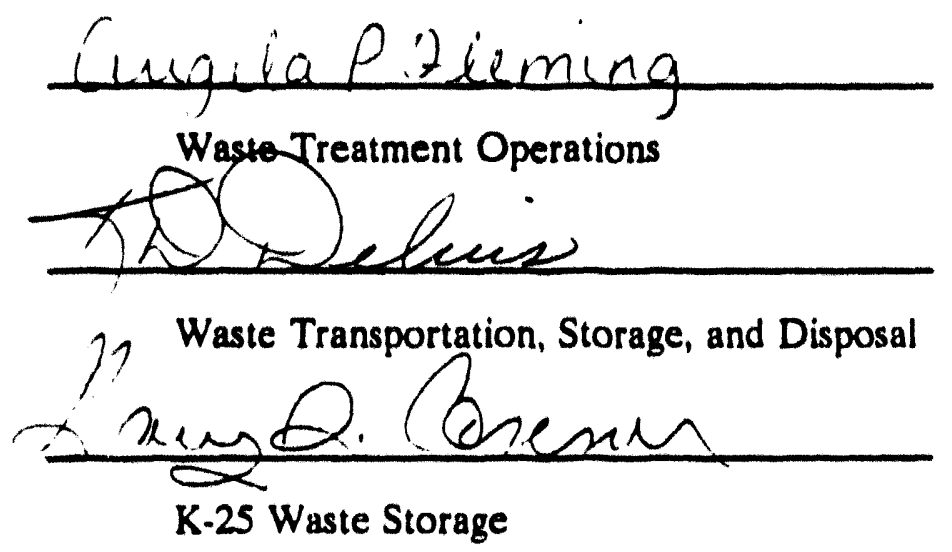

Date:

$2-10-93$
$2-11 \cdot 93$

$\underline{2-10-93}$

$$
02-1=n=
$$




\section{DISTRIBUTION}

$\begin{array}{rll}1 . & \text { L. } & \text { D. Bates } \\ 2 . & \text { D. T. Bell } \\ 3-7 . & \text { D. F. Bennelt } \\ 8 . & \text { K. D. Delius } \\ 9 . & \text { M. F. P. DeLozier } \\ 10 . & \text { B. Hallman } \\ 11 . & \text { P. J. Halsey } \\ 12 . & \text { R. M. Hill } \\ 13-14 . & \text { A. K. Lee/DOE-OSTI } \\ 15-18 . & \text { D. M. Matteo } \\ 19 . & \text { H. C. Newsome } \\ 20 . & \text { M. J. Norris } \\ 21-22 . & \text { P. T. Owen } \\ 23 . & \text { G. E. Rymer }\end{array}$
24. T. S. Newsome
25. D. E. Sparkman
26. S. V. Thomas
27. R. R. Turner
28. T. L. Voskuil
29. D. R. Watkins
30. R. L. Whaley
31. R. K. White
32. G. A. Yarborough
33. $Y \cdot 12$ Technical Library
34-38. ER Document Management Center
39. $Y-12$ ER Document Management Center
40. $Y \cdot 12$ Central Files
41. Y-12 ER Program

42. R. L. Carlson, Radian Corporation, 120 South Jefferson Circle, Oak Ridge, TN 37830

43-45. J. H. Darden, MK-Ferguson of Oak Ridge Company, P. O. Box 2001-9114, Oak Ridge, TN 37831

46. J. L. Howard, Department of Energy Oak Ridge Operations Office, P.O. Bux 2001, Oak Ridge, TN 37831-854i

47-56. S. L. Lankford, Department of Energy Oak Ridge Operations Office, P.O. Box 2001, Oak Ridge, TN 37831.8541

57-58. R. L. Nace, Branch Chief, Nonenrichment Facilities, Oak Ridge Program Division, Office of Eastern Area Programs, Office of Environmental Restoration, EM-423, Trevion 2, U.S. Department of Energy, Washington, DC, 20585

59. D. W. Swindle, Radian Corporation, 120 South Jefferson Circle, Oak Ridge, TN 37830

60-61. H. M. Thron, Chief, Enrichment Facilities, Oak Ridge Program Division, Office of Eastern Area Programs, Office of Environmental Restoration, EM-423, Trevion 2, U.S. Department of Energy, Washington, DC, 20585 

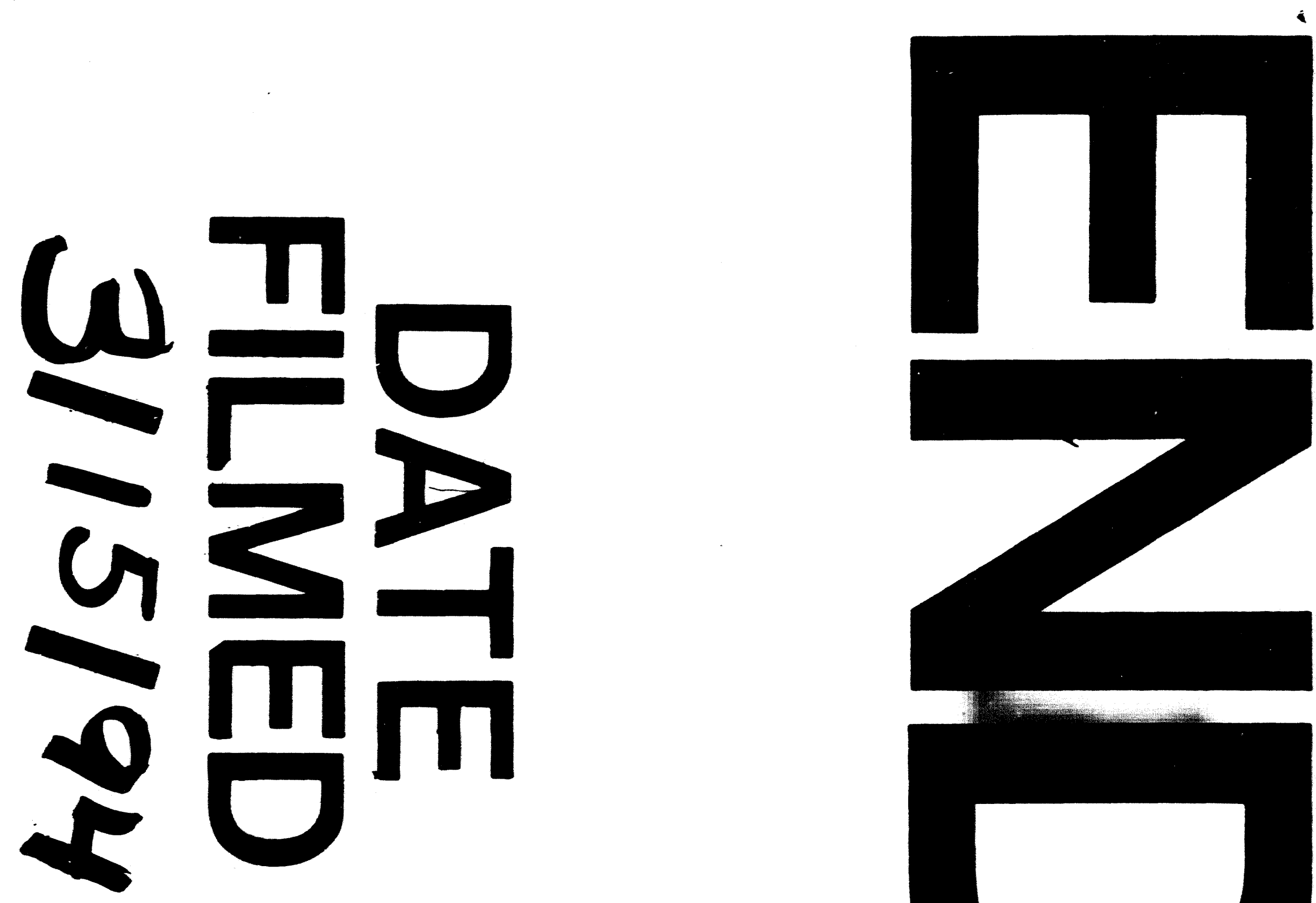

7)

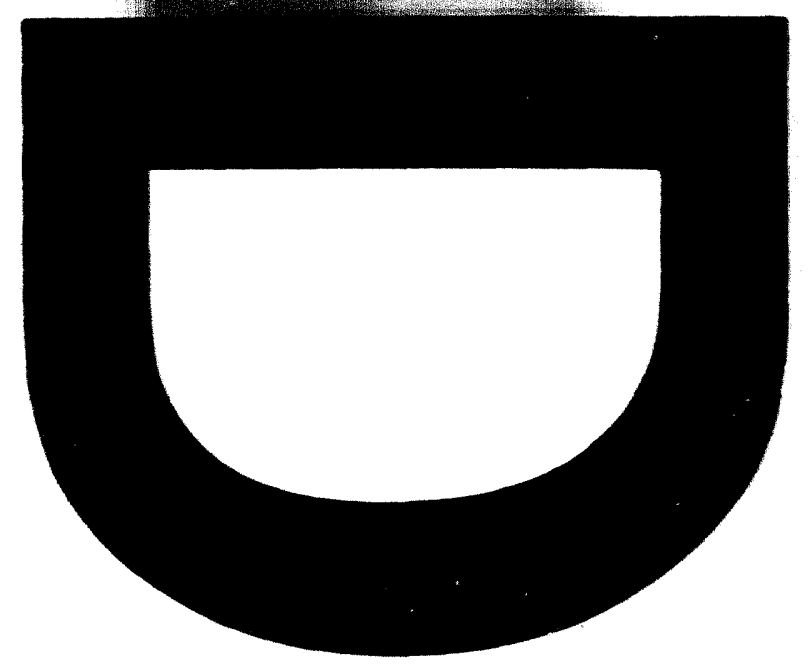




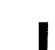

